\title{
結核菌站ビ二數種抗酸性菌ノ酸素 新陳代謝二就テ
}

（昭和 9 年 10 月 26 日受付）

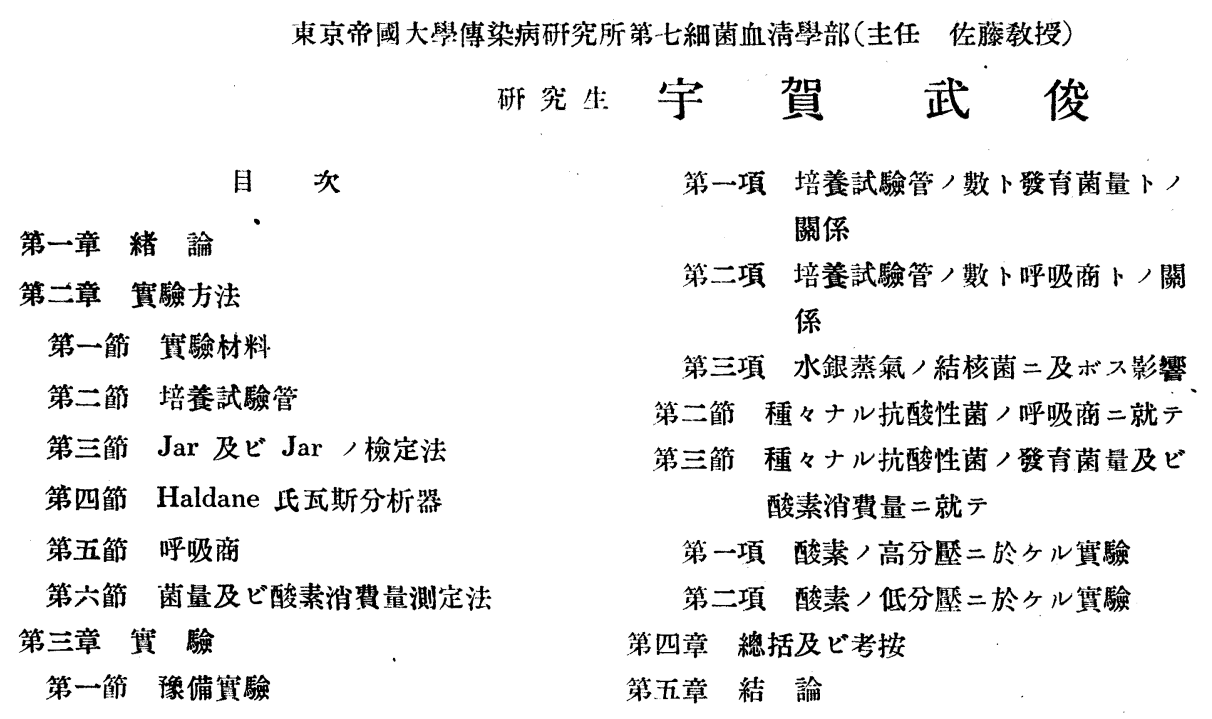

\section{第一章 緒 論}

抗酸性菌中結核菌，呼吸二關スル業績ハ1925 年ニ於ヶル F. G. Novy 及ビ M. H. Soule (1)， 實驗 基上二人型結核菌 $\mathrm{H}_{37}$ ヨ接種シソレヨ所謂 Novy，Jar 中二密閉シテ種々ナル酸素ノ濃度， 下=血溫二培養後 Jar 中, 瓦斯 7 分析シソ, 呼吸代謝, 狀態 7 觀察シテ結核菌二必要ナル酸素 , 需要量及ビ發青二好適ナル酸素, 濃度ヨ明カニセリ。

Novy 等, 研究ニヨレバ結核菌ニ必要ナル酸素, 最適濃度ハ $40 \%$ 乃至 $50 \%$ ト $70 \%$ 以上八寧 口有害ナリトス。然シ $100 \%$ ナ酸素ノ狀態ノ下ニテモ何發育シテ變種ヨ生ブトイへリ。又呼吸商 ᄏ测定シ glycerol agar ニテハ0.836, glucose agar ニテハ0.992, serum agar ニテハ0.904ナ ル數ヨ得タリ。而シテ結核菌, 發育速度卜發有量, 如何、 glycerol ヨ用ヒタル時最大ニシテ glucose 及ビ serum 、 glycerol 程大ナル發育力 7 結核菌二賦與セズト言つ。然レ共 Novy 等,

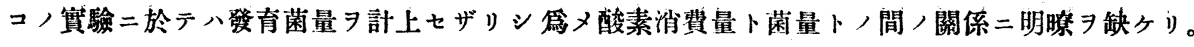
1932 年青木氏 (2)八數種八抗酸性菌ヨ種々ナル培養基上二移植シ Kipp，裝置二集メタル酸素 Harris, 方法ニョリ一八倛空ニシタル培養試驗管二導キ一八 manometer 二通ジテ $50 \mathrm{~mm}$ 乃至 $700 \mathrm{~mm}$ ，種々ナル酸素，分枤，下二培養後菌，發育狀態，色素形成，形態的戀化，變種形成等

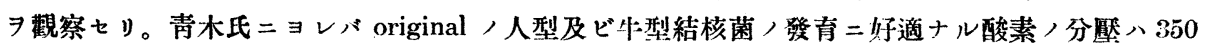


$\mathrm{mm}=$ テ最適度二到スルニ反シ冷血動物中, 蛙, 結核菌及ビ所謂癩菌ハ $50 \mathrm{~mm}$ 乃至 $100 \mathrm{~mm}$ / 低 張, 酸素, 分壓ニテ最適度二到ス卜言つ。而シテ S-型, 粘核菌及ビ同ジク timothy 菌及ビ B. C. G. 八酸素,需要量八Kedrowsky，瀨菌ノ夫レ二近似スルト言へリ。又人型及ビ牛型結核菌八 低張, 酸素, 分厴,下二テ S-型, 菌二似タル集落 7 形成スト言フ。

1932年 Soule (3) E. B. Mckinley ト共= glycerol broth potato, Petroff's egg, Dorset's egg, hormone glycerol agar $\exists$ 用ヒテ酸素及ビ炭酸, 種々ナル濃度,下二颗菌 7 培養シ結核菌同樣 $\mathrm{O}_{2} 40 \%, \mathrm{CO}_{2} 10 \%$ ，氣中二於テ最モ良好ナル發奆 7 得タリ。

1912 年 Marie and Tiffeneau ${ }^{(4)}$ 及ビ A. Frouin ${ }^{(5)}$ 八結核菌二及ボス $\mathrm{CO}_{2}$ ，影響 7 觀察シテ高 張， $\mathrm{CO}_{2}$ 八發育 7 阻止スルモ低張， $\mathrm{CO}_{2}$ ハ却ッテ發青 7 助長スル $、$ 見タリ。又 1918 年 Wherry and Ervin ${ }^{(6)}$ 、 $\mathrm{CO}_{2}+キ$ メ八 $7 \mathrm{~mm}$ 以下, 分壓， $\mathrm{CO}_{2}$ ，下二テハ結核菌、發青七ブ $17 \mathrm{~mm}$ 乃至 $47 \mathrm{~mm} ， \mathrm{CO}_{2}$ ，分壓二テ始メテ發青习始ムトイヘリ。

1921 年 Corper, Gauss and Rensgh (7) 八 $0.04 \% ， \mathrm{CO}_{2}$ 八結核菌，發育二好都合ナルモ $3 \%$ 乃至 $6 \%$ 以上， $\mathrm{CO}_{2}$ 八有害ナリトイヘリ。故二密閉シタル容器中二培養シタル場合ニハ結核菌 八發㕕卜共二生ブル $\mathrm{CO}_{2}$ が $5.5 \%$ 二到レバ培養試驗管，細菌，發育、阻止サルト見ザル可カラ ズ。然レ共 Novy 等、 $90 \% \mathrm{CO}_{2}, 10 \% \mathrm{O}_{2}$ ，氣中二於テモ可ナリ良キ發青 バ Corper 等, 實驗ハ正鴙ヨ得タルモノニ非ズト思惟ス。

1932 年 Dieckmann 八 Ludwig, Lange ${ }^{(8)}$ 卜共二Warburg，器械 $ᄏ$ 多少戀更シテ人型結核菌 ，酸素消費量 7 測定シ $1 \mathrm{mg} 1$ 時間二於テ $\mathrm{O}_{2} 20 \mathrm{cmm} ナ ル \exists$ 知レリ。又 R. O. Loebel (9) 等八 1933 年同ジク.Warburg 八檢査法二ョリ人型結核菌 $\mathrm{H}_{37} \rightarrow$ 用 心゙ Novy 等,實驗二大體合致セル成績 スルモノニシテヌ同氏等, 培飬試驗ヨリスレバ glucose モ又結核菌，呼吸 7 刺载スルモ5\%， 濃度二於テ，發育不良ニシテ glycerol，代用トシデ用ュルニ足ラズト言つ。

1933 年 M. Akszauzew(10) 八又 Warburg ，檢査法二依りテ抗酸性菌，呼吸及ビ解糖 $ᄏ$ 同時二 調べ $\frac{\text { aerobic glycolysis }}{\text { respiration }}$, 比が人型及ビ牛型結核菌ニテハ $1.27-0.6$ ，間二存ジ B. C. G. 外弱 毒ノモノ八0.21-0.17八間二存ジ又病原性ノ菌特二毒力强キモノ八弱毒ノモノ二比シ好氣性， 解糖作用强刀且ッ人型結核菌卜牛型結核菌,間二八物質代謝，點 ニテ特ニ著明ナル差異ナキコ トヨ知レリ。

以上 Novy, 青木氏等 $尹$ 除キテハ皆 Warburg，器械 7 用ヒテ测定シタル成績ナレ共一方 Rhoda Erdmann $n^{(11)}$ 、Warburg $=ョ ル$ 测定、 dying bacillus , respiration ニシテ growth シッ、ア ル bacillus, respiration $\ni$ 測定シ得ザル憾アリト言フ異論

余八以上先人ノ諸報告二鑑ミglycerol broth $ᄏ$ 用ヒテ種 タナル酸素, 濃度ノ下二數種ノ抗酸

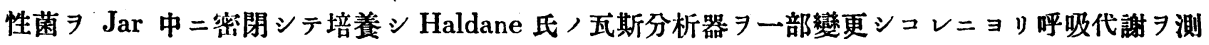
定シテ各菌株, 呼吸商 7 比較シ加之培養後, 菌量 $ᄏ$ 科量シテ發青二好適ナル酸素, 濃度及ビ酸 素消費量卜發育菌量卜，間，關係 7 數字的二表ハシ Novy, 青木等，賽驗二於テ見タル成績 屠精細二且ツ搌大シテ知ラントシ一方又牛型結核菌卜人型結核菌卜，間二酸素消費量，點二於 テ差異ナキャ又 Akszauzew，言フガ如ク果シテ呼吸代謝，點二强毒菌卜弱毒菌，間ニ著明ナル 差異アリヤ否ヤヨ磪カメントシテュノ實驗ニ志シタリ。 


\section{第二章 實驗方法}

\section{第一節 實驗材料}

新タ二分離シタル牛型結核茵 No. 2 , No. 3 , No. 6 , No. 12 , No. 14 及ビ傳染 病研究所二永ラク保存セラレタル弱毒菌ノ北研牛型菌及ビ人型結核菌トシテ上池三 代，青山 B，松本，其他 B.C.G. 菌及ビ鳥型結核菌，timothy 菌子使用セリ。

\section{第二節 培養試驗管}

培養試驗管ノ大サハ $200 \mathrm{~mm} \times 25 \mathrm{~mm}$ ノモノ二綿栓キ緩ニシ PH 6.8 - 7.0 トシタル $5 \%$ glycerol broth $尹 20$ c.c. 入レタルモノキ用フ。

\section{第三節 Jar 及ビ Jar 檢定法}

培養試驗管キ入ル、Jarハ細谷氏 anaerobic Jar キ一部變更シ容量ハ1000c.c一 3500 c.c.迄ノ大小種々ナルモノ用フ。コノJar /容量ノ計リ方ハ次ノ方法ニョル。

今大氣, 壓力 $7 \mathrm{P}_{1}$ トシ Jar ハ $\mathrm{V}_{1}$ c. c c 容量アルモノトス。而シテ Jar 中ノ空氣キ xc.c. 取リ去リタル時，Jar 中／㕍力尹 $\mathrm{P}_{2}$ トスル時ハ Boyle-Charles /法則ニョリ 次式ガ成立ス。

$$
\begin{gathered}
\left(\mathrm{V}_{1}-\mathrm{xc.c} .\right) \mathrm{P}_{1}=\mathrm{V}_{1} \mathrm{P}_{2} \\
\mathrm{~V}_{1} \mathrm{P}_{1}-\mathrm{xc.c} \mathrm{P}_{1}=\mathrm{V}_{1} \mathrm{P}_{2} \\
\mathrm{~V}_{1}\left(\mathrm{P}_{1}-\mathrm{P}_{2}\right)=\mathrm{P}_{1} \mathrm{xc.c} . \\
\mathrm{V}_{1}=\frac{\mathrm{P}_{1}}{\mathrm{P}_{1}-\mathrm{P}_{2}} \text { xc.c. }
\end{gathered}
$$

コレヨリ $V_{1}$ チ見出シ得。Jar ハ黃色「ワゼリン」ニテ密閉シ $37^{\circ} \mathrm{C}=$ 培養セリ。

\section{第四節 Haldane 氏死斯分析器}

Jar 中, 瓦斯分析ニハ Haldane 氏瓦斯分析器 ${ }^{(2)}$ キ使用七り。然シ Haldane , 原型 八20\%以上ノ酸素ノ濃度ハ測定シ得ザル故二 burette八構造き變更シテ全體ノ容積

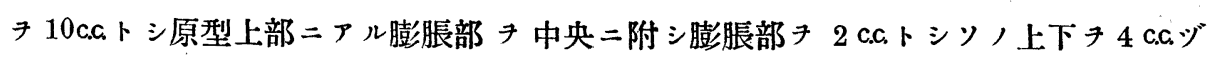
ツニ分ケ $\frac{1}{100}$ c. . 迄目盛セルモノキ用フ。カクスレバ殆ド $100 \%$ 酸素き測定シ得。炭 酸瓦斯八 $10 \%$ 苛性加里溶液キ以テ吸收セシメタリ。手塚氏 ${ }^{(13)}$ ，20\%苛性加里溶液が

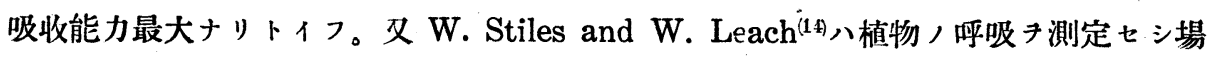
合 Katharometer 7 使用七り。之裝置八白金線, 周圍, 炭酸瓦斯/多少ニョリ白金 
線「コイル」ノ抵抗二變化き及ボスタ利用シソノ抵抗ノ差異タ電氣的ニ測定ス。コノ裝

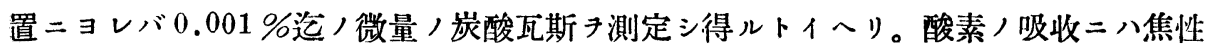

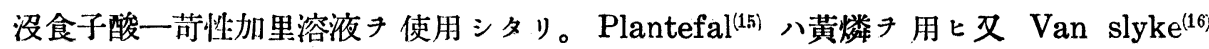
、Natrium-Antrahydrochinon- $\beta$-sulfonat 尹用ュレ共何レモ一長一短アリ。

\section{第五節 呼吸商}

Glycerol broth キ培地トシテ培養スル場合二酸素が消費サル、ヤ Jar 中二㓌壓き 生ズ。コノ理由八一八培地中二溶解スル $\mathrm{CO}_{2}$ ノ減少二歸入ルモ他方次式ニョリテ明 カナルガ如ク $\frac{1}{7}$, 酸素ハ $\mathrm{H}_{2}$ ト結合シテ水キ生ズルニヨルモノナリ。

$$
2 \mathrm{C}_{3} \mathrm{H}_{8} \mathrm{O}_{3}+7 \mathrm{O}_{2}=6 \mathrm{CO}_{2}+8 \mathrm{H}_{2} \mathrm{O}
$$

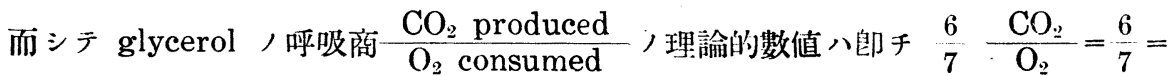
0.857 ナリ。實際 Jar 內ノ瓦斯キ測定スル場合二八前述ノ如ク $\mathrm{O}_{2}+\mathrm{CO}_{2}$ ）絕對量ガ 減少シテ陰壓 キ生ズル篇メ二 $\mathrm{N}_{2}$ 八表面上增加 示スモノナリ。

故 $=$ 窒素係數 $=\frac{\% \mathrm{~N}_{2} \text { control }}{\% \mathrm{~N}_{2} \text { found }}$ キラ表面上，呼吸商 $\left(=\frac{\mathrm{CO}_{2} \text { produced }}{\mathrm{O}_{2} \text { consumed }}\right)$ ，值 修正七ザル可カラズ。今大氣, 酸素及ビ炭酸瓦斯, 濃度,下二培養シタル時 $\mathrm{O}_{2}=$ $20.93 \%, \mathrm{CO}_{2}=0.03 \%, \mathrm{~N}_{2}=79.04 \%$ ル故二眞，呼吸商，值八次式二テ見出サ ル。

眞, 呼吸商 $=\frac{(\mathrm{N} . \mathrm{f} \times \mathrm{a})-0.03}{20.93-\left(\mathrm{N}_{2} \mathrm{f} \times \mathrm{b}\right)}$

$\mathrm{N}_{2} \mathrm{f}=$ 窒素係數

$\mathrm{a}=\mathrm{CO}_{2} \%$ found, $\mathrm{b}=\mathrm{O}_{2} \%$ found

今實例 以テ示セバ人型結核菌青山 B $5 \%$ glycerol broth キ入レタル培養試驗

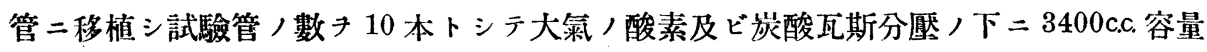
, Jar 中二密閉シテ $37^{\circ} \mathrm{C}$ 二培養シタル時最初, Jar 內ノ酸素及ビ炭酸瓦斯及ビ窒 素，濃度ハ郎チ $\mathrm{O}_{2}=20.93 \%, \mathrm{CO}_{2}=0.03 \%, \mathrm{~N}_{2}=79.04 \%$ リ。而シテ 2 週間目二 八 Jar 內ニハー10 mm ナル㓌壓キ生ズ。コノ時，Jar 內ノ瓦斯キ分析スル時ハ $\mathrm{O}_{2}=$ $4.427 \%, \mathrm{CO}_{2}=13.998 \%, \mathrm{~N}_{2}=81.575 \%$ ニ䇪素八最初 $79.04 \%$ アタルモノガ $81.575 \%$ 二增加ス。窒素が增加スルト言フコトハアリ得ベカラザル事ニテえハ明カニ 培養液二溶解シタル炭酸瓦斯ノ減少, 䉆メト一八酸素ガ水素卜絬合シテ水形成シタ

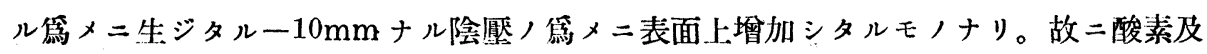
ビ炭酸瓦斯モ窒素/增加セル割合ダケ同樣表面上增加セザル可カラズ。故二窒素， 增加セル割合郎チ最初，窒素，數 $79.04 \%$ 卜最後，表面上增加七ル數 $81.575 \%$ 比 
$\frac{79.040}{81.575}=0.9689$ ナル窒素係數キ以テ表面上增加七ル酸素及ビ炭酸瓦斯ノ數き修正 セザル可カラズ。酸素ノ表面上ノ數ハ $4.427 \%$ ，炭酸瓦斯 / 表面上ノ數ハ $13.998 \%$ ナル故二

$$
\begin{aligned}
\text { 表面上, 呼吸商 } & =\frac{13.998-0.03}{20.93-4.427}=0.8463 \text { ニシテ } \\
\text { 真, 呼吸商 } & =\frac{(13.998 \times 0.9689)-0.03}{20.93-(4.427 \times 0.9689)} \\
& =\frac{13.563-0.03}{20.93-4.288}=0.8131+\text { ナ. }
\end{aligned}
$$

\section{第六節 菌量及酸素消費量測定方法}

移植菌ハ PH 6.8一7.0 J $5 \%$ glycerol broth = 2 週間培養ノ薄キ膜き選ビ值徑 1 $\mathrm{cm}$ /渦卷白金耳キ以テ探取シ最初ノ移植菌量ハ $5 \mathrm{mg}$ 内外ニナル樣練習き重サヌ。既 二黑屋氏 ${ }^{(17)}$ )實驗ノ如ク 3 䓢間後, 發育菌量八移植菌量二多少ノ大小アルモ比較的關 係ナク一定ナリ。而シラ培養後科量スベキ菌ハ $100^{\circ} \mathrm{C} 30$ 分間隇菌シコレナ滤過シ菌

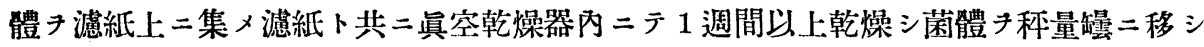
化學天科ニテ科量シタリ。本實驗二於ケル菌量ハ全テ乾燥菌量ノ數き以テ表ハスコト トセリ。今科量シタル菌體, 重量き X mg トシ酸素ノ消費量き $\mathrm{V}_{1}$ c.c. トスレバ最初ノ 移植菌量ハ $5 \mathrm{mg}$ ナル故二菌體 $1 \mathrm{mg}$ 發吉二要スル酸素ノ消費量 $\mathrm{V}=\frac{\mathrm{V}_{1} \mathrm{ccc} .}{\mathrm{x}-5}$ ナリ。見 出サレタル容積八全テ $0^{\circ} \mathrm{C} 760 \mathrm{~mm}$ ，標準狀態二修正七り。修正方法ハ Boyle-Charles ノ法則ヨリ誘導シタル次式キ用フ。

$$
\begin{aligned}
& \quad \mathrm{V}_{0}=\frac{\mathrm{V}_{\mathrm{t}}}{1+a} \frac{(\mathrm{B} \pm \mathrm{b}-\mathrm{T})}{760} \\
& \mathrm{~B}=\text { 出發時ノ氣厭 } \\
& \mathrm{b}=\text { Manometer 二表ハレタル壓力 (修正濟) } \\
& \mathrm{T}=\mathrm{t}^{\circ} \mathrm{C} \text { 二於ケル飽和蒸氣㻺 } \\
& \mathrm{V}_{\mathrm{t}}=\mathrm{t}^{\circ} \mathrm{C} \text { 二於ケル瓦斯容積 } \\
& \mathrm{V}_{0}=0^{\circ} \mathrm{C}=\text { 於ケル瓦斯容積 } \\
& a=\text { 瓦斯膨脹係數 }=0.003666
\end{aligned}
$$

\section{第三章 實 驗}

\section{第一節 豫備實驗}

第一項 培養試驗管 數卜發有菌量卜 /關係

人型結核菌青山 B 及ビ牛型結核菌 No. 2 キ $5 \%$ glycerol broth 20 c.a. 入レタル試 
Table I.

Analyses and oxygen requirement of human tubercle bacilli (Aoyama B.) grown on glycerol broth of one tube.

\begin{tabular}{|c|c|c|c|}
\hline No. of experiment & I & II & III \\
\hline Experimental material & Aoyama B. & Aoyama B. & Aoyama B. \\
\hline No. of days & 7 & 14 & 21 \\
\hline No. of tubes & 1 & 1 & 1 \\
\hline Net volume of Jar & 3596 & 3596 & 1610 \\
\hline Manometer & -7 & -8 & -11 \\
\hline $\begin{array}{ll}\text { Barometer } & \\
& \text { Initial } \\
& \text { Final }\end{array}$ & $\begin{array}{l}756.7 \\
753.7\end{array}$ & $\begin{array}{l}753.7 \\
757.1\end{array}$ & $\begin{array}{l}761.1 \\
760.7\end{array}$ \\
\hline $\begin{array}{l}\text { Temperature } \\
\text { Initial } \\
\text { Final }\end{array}$ & $\begin{array}{c}23 \\
20.5\end{array}$ & $\begin{array}{l}20.5 \\
24\end{array}$ & $\begin{array}{l}21 \\
20\end{array}$ \\
\hline $\begin{array}{ll}\text { Analyses } & \\
& \mathrm{CO}_{2} \\
& \mathrm{O}_{2}\end{array}$ & $\begin{array}{r}0.219 \\
20.467\end{array}$ & $\begin{array}{r}1.554 \\
19.308\end{array}$ & $\begin{array}{r}13.197 \\
6.283\end{array}$ \\
\hline $\begin{array}{ll}\text { C. c. } \mathrm{O}_{2} \text { at } \mathrm{O} \text { degree; } \\
760 \mathrm{~mm} & \text { Initial } \\
& \text { Final }\end{array}$ & $\begin{array}{l}671 \\
664\end{array}$ & $\begin{array}{l}678 \\
618\end{array}$ & $\begin{array}{r}309 \\
84\end{array}$ \\
\hline $\mathrm{O}_{2}$ loss & 7 & 60 & 225 \\
\hline $\begin{array}{l}\text { Dry weight of bacilli in } \\
\text { mgs. }\end{array}$ & 12 & 60 & 148 \\
\hline$\frac{\text { Consumed } \mathrm{O}_{2}}{\text { Dry weight of bacilli }}$ & 1 & 1.1 & 1.6 \\
\hline
\end{tabular}

$\mathrm{CO}_{2}=0.03 \quad \mathrm{O}_{2}=20.93 \quad \mathrm{~N}_{2}=79.04$

Chart 1.

The growth and consumed oxygen curve of human tubercle bacilli(Aoyama B.) grown on glycerol broth of one tube.

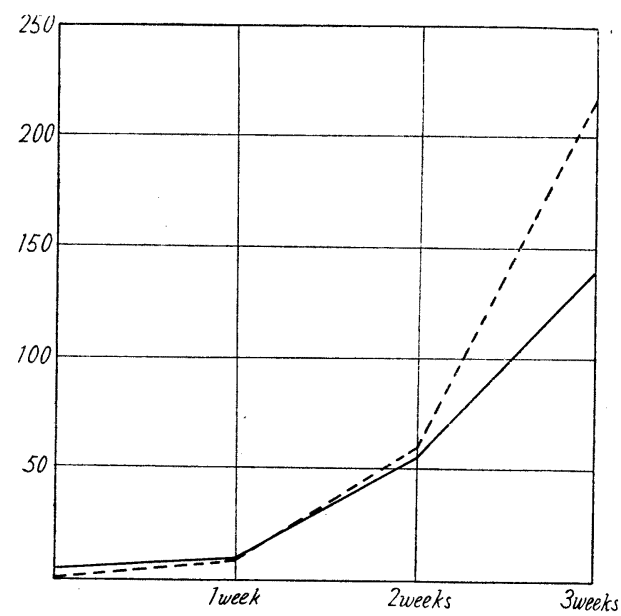

Dry weight of bacilli in mgs. ...... Consumed oxygen amount in ac 
驗管二移植シ大氣ノ酸素ノ濃度郎チ $20.93 \%$,下二試驗管ノ數キ各 1 本及ビ 10 本トシ テ 3000c.c. 乃至 $3500 \mathrm{cc}$ ／容量，Jar 中二密閉シテ 1 週間培養， 2 週間培養， 3 週間 培養ノ酸素需要量及ビ發有菌量タ表示スレバ第 1 表乃至第 4 表ノ如シ。

Table I 八人型結核菌青山B. 尹 glycerol broth /試驗管 1 本二培養七儿賏驗二シ テ Experiment I ハ 1 週間培養ノ成績ナリ。コ）實驗二於テ酸素消費量ハ7c.c.二對

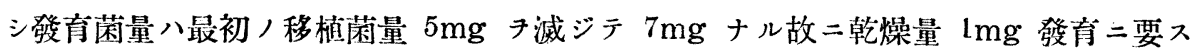
ル酸素消費量ハ 1 c.a.リリ Experiment II ハ 2 逓間培養ノ成績ニシテ酸素消費量 60 c.c. 二對シ發育菌量 $55 \mathrm{mg}$ ニシテ $1 \mathrm{mg}$ 發育二要スル酸素ハ $1.1 \mathrm{c} . c$ ナリ。Experiment III 八 3 週閒培養，成績ニシテ 酸素消費量 $225 \mathrm{ccc}$. 二對シ發育菌量 $143 \mathrm{mg}$ ニシテ $1 \mathrm{mg}$ 發 有菌量二對シ 1.6ca，酸素キ消費ス。之等ノ關係尹 curve ニテ表ハス時ハ Chart 1 ノ如シ。師于酸素消費量, 增加卜共二菌量モ次第二站行シテ增加シ 1 週間後八增加率

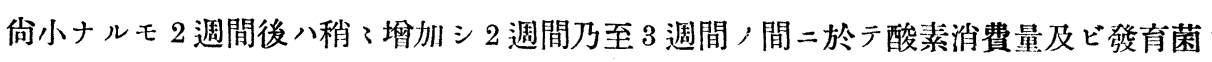
量共二最大二到ス。1 $\mathrm{mg}$ 溌有二要スル酸素量モ 3 週間培養ノモノ最大ナリ。

Table II.

Analyses and oxygen requirement of human tubercle bacilli (Aoyama B.) grown on glycerol broth of ten tubes.

\begin{tabular}{|c|c|c|c|}
\hline No. of experiment & I & II & III \\
\hline Experimental material & Aoyama B. & Aoyama B. & Aoyama B. \\
\hline No. of days & 7 & 14 & 21 \\
\hline No. of tubes & 10 & 10 & 10 \\
\hline Net volume of Jar & 3410 & 3410 & 3410 \\
\hline Manometer & -29 & -10 & -15 \\
\hline $\begin{array}{cl}\text { Barometer } & \begin{array}{l}\text { Initial } \\
\text { Final }\end{array} \\
\end{array}$ & $\begin{array}{l}753.9 \\
757.6\end{array}$ & $\begin{array}{l}757.6 \\
759.3\end{array}$ & $\begin{array}{l}759.3 \\
758.2 \\
\end{array}$ \\
\hline $\begin{array}{c}\text { Temperature } \\
\text { Initial } \\
\text { Final }\end{array}$ & $\begin{array}{l}25.5 \\
23 \\
\end{array}$ & $\begin{array}{l}23 \\
28 \\
\end{array}$ & $\begin{array}{l}28 \\
31 \\
\end{array}$ \\
\hline $\begin{array}{lr}\text { Analyses } & \mathrm{CO}_{2} \\
& \mathrm{O}_{2} \\
\end{array}$ & $\begin{array}{r}3.875 \\
16.909\end{array}$ & $\begin{array}{r}13.998 \\
4.427 \\
\end{array}$ & $\begin{array}{r}16.593 \\
1.185 \\
\end{array}$ \\
\hline $\begin{array}{cc}\text { C. c. } \mathrm{O}_{2} \text { at } & \mathrm{O} \text { degree, } \\
\text { 760mm } & \text { Initial } \\
& \text { Final } \\
\end{array}$ & $\begin{array}{l}627 \\
494\end{array}$ & $\begin{array}{l}637 \\
123 \\
\end{array}$ & $\begin{array}{r}622 \\
31 \\
\end{array}$ \\
\hline $\mathrm{O}_{2}$ loss & 133 & 514 & 591 \\
\hline $\begin{array}{l}\text { Dry weight of bacilli in } \\
\text { mgs }\end{array}$ & $\begin{array}{l}13.13 .12 .25 .19 \\
20.22 .22 .12 .18 \\
\end{array}$ & $\begin{array}{l}42.57 .59 .55 .48 \\
47.20 .45 .47 .48 \\
\end{array}$ & $\begin{array}{l}53.58 .57 .41 .45 \\
55.53 .50 .63 .48 \\
\end{array}$ \\
\hline Total & 176.5 & 4.68 & 523 \\
\hline $\begin{array}{c}\text { Consumed } \mathrm{O}_{2} \\
\text { Dry weight of bacilli }\end{array}$ & 1 & 1.2 & 1.2 \\
\hline
\end{tabular}

$$
\mathrm{CO}_{2}=0.03 \quad \mathrm{O}_{2}=20.93 \quad \mathrm{~N}_{2}=79.04
$$


Chart 2.

The growh and consumed oxygen curve of human tubercle bacilli (Aoyama B.) grown on glycerol broth of ten tubes.

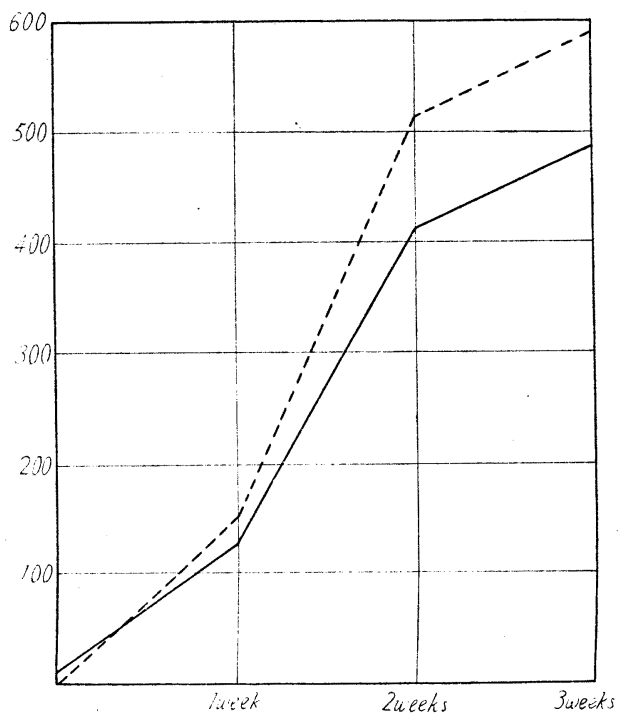

Dry weight of bacilli in mgs.

-...- Consumed oxygen amount in c.a.

Table II ハ同ジク人型結核菌青山 B. チ10本，glycerol brothノ試驗管二培養七 ル實驗ニシテ Experiment I ハ 1 週間培養, 成績ナリ。郎チ酸素消費量 $133 c . c$. 二對

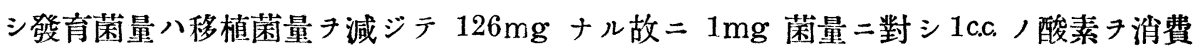
ス。Experiment II ハ 2 週間培養ノ成績ニシテ酸素消費量 $514 \mathrm{ccc}$ 二對シ發有菌量 418

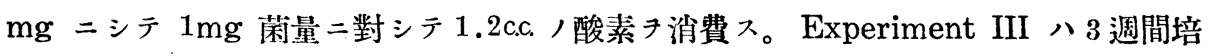
養ノ成績ニシテ酸素消費量 $591 \mathrm{ccc}$. 二對シ發有菌量 $483 \mathrm{mg}$ ニシテ $1 \mathrm{mg}$ 菌量二對シ 1.2 c.c. 酸素ヨ消費ス。10 本ノ場合ハChart 2 二テ見ル如ク 1 本ノ場合卜異ナリ 2 週間

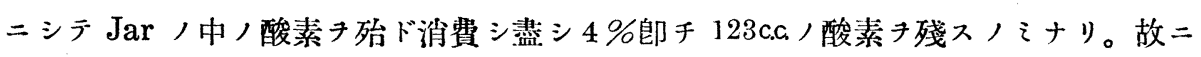
3 週間培養後卜雖モ 2 週間培養,モノ二比 シ酸素消費量モ發育菌量モ共二僅二增加入 ルニ過ギズ。郎チ 2 週間ニシテ發青殆ド停止、ス狀態ナルモ少良ク 123 c.c. ，酸素キ利 用シテ發育菌量 2 週間培養ノモノョリ多シ。

Table III. 八牛型結核菌 No. 2 7 glycerol broth ，試驗管 1 本二培養七几頯驗二 シテ Experiment I. ハ 1 週閒培養 成績ナリ。郎チ酸素消費量 $51 \mathrm{ccc}$. 對シ發苚菌量

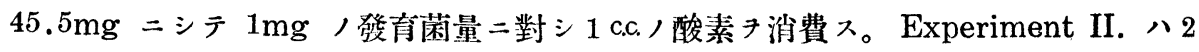
週間培養,成績ニシテ酸素消費量 $196 \mathrm{ccc}$. 二對シ發育菌量 $139 \mathrm{mg}$ ニシテ $1 \mathrm{mg}$ 二對シテ 1.3c.c. ノ酸素き消費ス。Experiment III. ハ 3 週間培養 成績ニシテ酸素消費量 $283 \mathrm{ccc}$. 
Table III.

Analyses and oxygen requirement of bovine tubercle bacilli (No. 2.) grown on glycerol broth of one tube.

\begin{tabular}{|c|c|c|c|}
\hline No. of experiment & $\mathbf{I}$ & II & III \\
\hline Experimental material & Bovine (No. 2) & Bovine (No. 2) & Bovine (No. 2) \\
\hline No. of days & 7 & 14 & 21 \\
\hline No of tubes & 1 & 1 & 1 \\
\hline Net volume of Jar & 3590 & 3590 & 3590 \\
\hline Manometer & -28 & -53 & -20 \\
\hline $\begin{array}{ll}\text { Barometer } & \\
& \text { Initial } \\
& \text { Final }\end{array}$ & $\begin{array}{l}756.7 \\
753.7\end{array}$ & $\begin{array}{l}753.7 \\
757.1\end{array}$ & $\begin{array}{l}757.1 \\
752.2\end{array}$ \\
\hline $\begin{array}{l}\text { Temperature } \\
\text { Initial } \\
\text { Final }\end{array}$ & $\begin{array}{l}23 \\
20.5\end{array}$ & $\begin{array}{l}20.5 \\
24\end{array}$ & $\begin{array}{l}24 \\
31\end{array}$ \\
\hline $\begin{array}{lr}\text { Analyses } & \mathrm{CO}_{2} \\
& \mathrm{O}_{2} \\
\end{array}$ & $\begin{array}{r}1.110 \\
19.865\end{array}$ & $\begin{array}{r}4.065 \\
16.129 \\
\end{array}$ & $\begin{array}{r}7.300 \\
13.000 \\
\end{array}$ \\
\hline 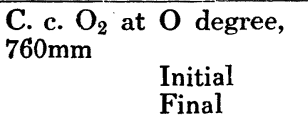 & $\begin{array}{l}670 \\
619\end{array}$ & $\begin{array}{l}672 \\
476\end{array}$ & $\begin{array}{l}667 \\
384\end{array}$ \\
\hline $\mathrm{O}_{2}$ loss & 51 & 196 & 283 \\
\hline $\begin{array}{l}\text { Dry weight of bacilli in } \\
\text { mgs }\end{array}$ & 50.5 & 144 & 187 \\
\hline$\frac{\text { Consumed } \mathrm{O}_{2}}{\text { Dry weight of bacilli }}$ & 1 & 1.3 & 1.5 \\
\hline
\end{tabular}

$$
\mathrm{CO}_{2}=0.03 \quad \mathrm{O}_{2}=20.93 \quad \mathrm{~N}_{2}=79.04
$$

Chart 3.

The growth and consumed oxygen curve of bovine tubercle bacilli (No. 2) grown on glycerol broth of one tube.

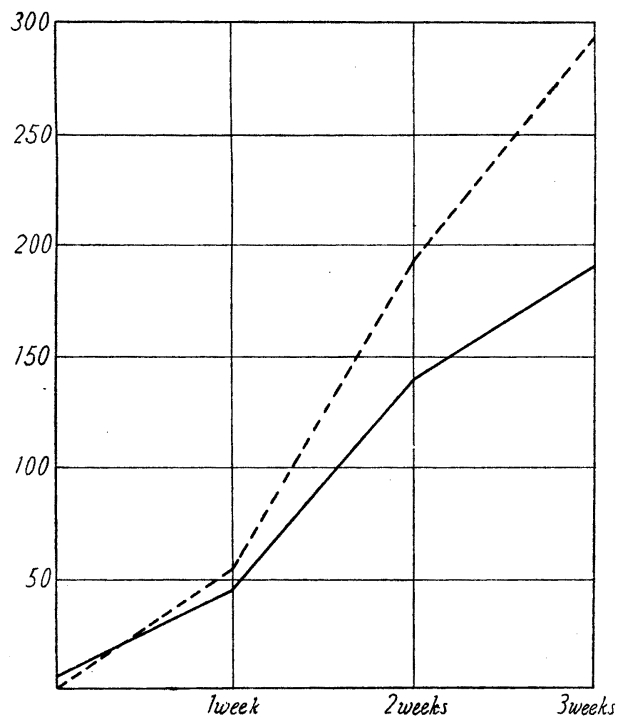

Dry weight of bacilli in mgs.

- Consumed oxygen amount in ac. 
Table IV.

Analyses and oxygen requirement of bovine tubercle bacilli (No. 2) grown on glycerol broth of ten tubes.

\begin{tabular}{|c|c|c|c|}
\hline No. of experiment & $\mathrm{I}$ & II & III \\
\hline Experimental material & Bovine (No. 2) & Bovine (No. 2) & Bovine (No. 2) \\
\hline No. of days & 7 & 14 & 21 \\
\hline No. of tubes & 10 & 10 & 10 \\
\hline Net volume of Jar & 3400 & 3400 & 3400 \\
\hline Manometer & -42 & -48 & -16 \\
\hline $\begin{array}{ll}\text { Barometer } & \\
& \text { Initial } \\
& \text { Final }\end{array}$ & $\begin{array}{l}753.7 \\
752.1\end{array}$ & $\begin{array}{l}752.1 \\
766.9\end{array}$ & $\begin{array}{l}766.9 \\
756.4\end{array}$ \\
\hline $\begin{array}{c}\text { Temperature } \\
\text { Initial } \\
\text { Final } \\
\end{array}$ & $\begin{array}{l}20.5 \\
22\end{array}$ & $\begin{array}{l}22 \\
28.5 \\
\end{array}$ & $\begin{array}{l}28.5 \\
33\end{array}$ \\
\hline $\begin{array}{l}\text { Analyses } \\
\qquad \mathrm{CO}_{2} \\
\mathrm{O}_{2}\end{array}$ & $\begin{array}{r}9.112 \\
10.920 \\
\end{array}$ & $\begin{array}{r}17.162 \\
1.103 \\
\end{array}$ & $\begin{array}{r}16.498 \\
0.406 \\
\end{array}$ \\
\hline $\begin{array}{ll}\text { C. c. } \mathrm{O}_{2} & \text { at } \mathrm{O} \text { degree, } \\
760 \mathrm{~mm} & \begin{array}{l}\text { Initial } \\
\\
\end{array} \\
& \text { Final }\end{array}$ & $\begin{array}{l}641 \\
311\end{array}$ & $\begin{array}{r}634 \\
30\end{array}$ & $\begin{array}{r}616 \\
10\end{array}$ \\
\hline $\mathrm{O}_{2}$ loss & 330 & 604 & 606 \\
\hline $\begin{array}{l}\text { Dry weight of bacilli in } \\
\text { mgs }\end{array}$ & $\begin{array}{l}24.41 .41 .38 .45 \\
36.38 .38 .25 .37 \\
\end{array}$ & $\begin{array}{l}61.54 .65 .43 .55 \\
50.53 .52 .52 .58\end{array}$ & $\begin{array}{l}62.54 .65 .48 .57 \\
50.54 .55 .54 .50\end{array}$ \\
\hline Total & 360 & 548 & 549 \\
\hline $\begin{array}{c}\text { Consumed } \mathrm{O}_{2} \\
\text { Dry weight of bacilli }\end{array}$ & 1 & 1.2 & 1.2 \\
\hline
\end{tabular}

Chart 4.

The growth and consumed oxygen curve of bovine tuercle bacilii (No. 2) grown on glycerol broth of ten tubes.

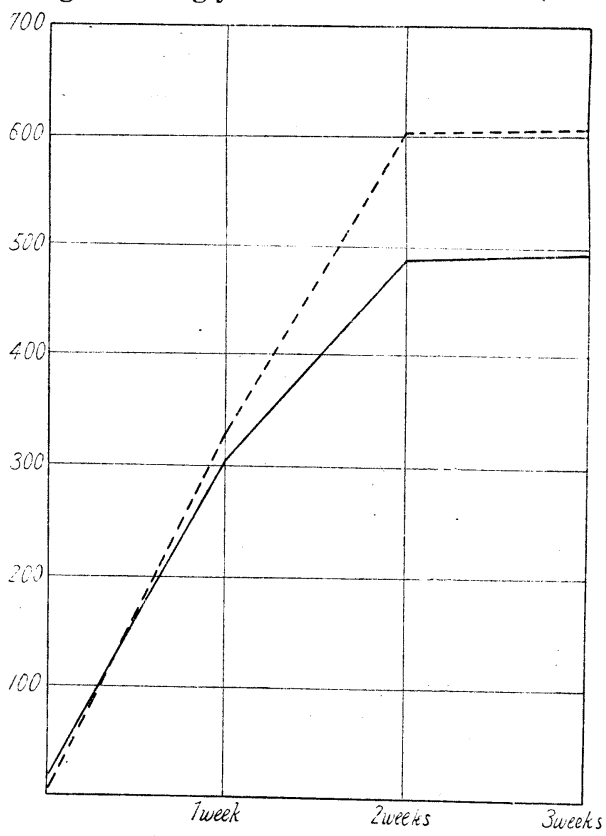

Dry weight of bacilli in mgs.

Consumed oxygen amount in c.c. 
二對シ發有菌量 $182 \mathrm{mg}$ ニシテ $1 \mathrm{mg}$ 二對シ 1.5 c.c. 酸素キ消費ス。えキ curve 二 テ表ハス時ハChart 3 ，如シ。郎于酸素消費量/增加卜共二菌量モ站行シテ增加シ 1 週間後ハ增加率未氺が小ルモ 2 週間後稍 3 增加シ 2 週間乃至 3 週間ノ間二於テ最大 二到ス。而シテ劣增加セントスル傾向き示ス。1 mg 發有菌量二對スル酸素消費量モ 3 週間培養ノモノ最大ナリ。

Table IV ハ牛型結核菌 No. 2 キ 10 本，glycerol broth，試驗管二培養セル實 驗ナリ。Experiment 1 八 1 週間培養，成績ニシテ酸素消費量 330 c.c. 二對 シ發有菌量 $310 \mathrm{mg}$. ナル故 $=1 \mathrm{mg}$ 發育菌量二對シ1.0c.c. ノ酸素き消費ス。Experiment II ハ 2 週間培養ノ成績ニシテ酸素消費量 $604 \mathrm{ccc}$ 二對シ菌量 $498 \mathrm{mg}$ ナル故 $=1 \mathrm{mg}$ 發有菌量二 對シ 1.2c.c. /酸素キ消費ス。Experiment III ハ 3 週間培養ノ成績ニシテ酸素消費量 606 c.c. 二對シ發有菌量 $499 \mathrm{mg}$. ニシテ $1 \mathrm{mg}$. 發㕕菌量二對シ 1. 2c.c. ノ酸素キ消費ス。 そョ curve ニテ表ハス時ハ Chart 4 ノ如シ。郎チ 2 週間ニシテ Jar 中ノ酸素キ殆 ド使用シ盡シ $1 \%$ 郎チ 30 c.c. キ殘スノそナリ。

以上ノ䔈驗キ總括スレバ 3000 c.c. 乃至 3500 c.c. ノ容量/Jar キ用ヒテ 1 本ノ試驗管二 培養スル場合ハ 2 週間後二人型結核菌青山 B. 八 $55 \mathrm{mg}$. 牛型結核茵 No. 2 八 $139 \mathrm{mg}$ 又 3 週間後八青山B. 八 143mg. 牛型結核菌. No. 2 八 $182 \mathrm{mg}$. /程度迄當然發育入べ キモノガ 10 本培養, 場合八酸素ノ不足ノ䉆メ二 2 週間後, 發育藏量靑山 B. 八 1 本ノ 發育菌量本均 $41 \mathrm{mg}$. ニシテ牛型結核菌 No. 2 八 $50 \mathrm{mg}$. ナリ。而シテ 3 週間培養ノモ

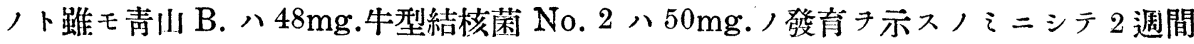
培養ノモノト變リナシ。份 $1 \mathrm{mg}$. 發育菌量二要スル酸素量ハ 10 本ノ場合ノ方 1 本ノ場 合二比シ稍了低シ。郎チ青山 B. ハ1.6c.c. : 1.2c.c. 牛型結核菌 No. 2 八 1.5 c.c.: 1.2 c.c. ， 比ニシテコノ誤差ノアルモノ八常然培養液二吸收サル、量雇慮ニ入レザルベカラズ。

今 Table II ト Table IV 尹比較考察スルニ Table II ニ於テハ 2 週間後, 培養, モノ八少 $4 \%$ 郎チ 100 c.c. 以上ノ酸素き殘入䉆メ倘良ク之き利用シテ 3 週間培養ノモ， ハ 2 週間培養ノモノニ比シ $65 \mathrm{mg}$. ，菌量，增加き示シ酸素消費量モ $77 \mathrm{ccc}$. 多シ。然ルニ Table IV ニテハ 2 週間培養ノモノニ於テ殆ド酸素き消費シ盡シ $1 \%$ 郎チ 30 c.c. チ殘 スノミナル故 3 週間培養ノ發有菌量及ビ酸素消費量ハ 2 週間培養ノモノト殆ド變りナ ク同樣ナリ。而カモ沿良ク $1 \%$ 郎チ $30 \mathrm{ccc}$.ナル僅カナル酸素 利用シ 3 週間培養ノモ ノニ於テハ $0.4 \%$ 郎チ $10 \mathrm{ccc}$. 二減少セルタ見ル。由之觀是結核菌ハNovy 等ノ言フガ 如ク 100 c.c. 八酸素キ供給シサエスレバ $4 \%$ 或ハ其以下，低張，酸素ノ下ニテモ少良ク 發育シ得ルモノニシテ要スルニ發育, 如何ハ酸素き供給スル Jar ，容量如何ニョル 
モノナリ。少コノ實驗二於テハ人型結核菌及ビ牛型結核菌ノ間二酸素ノ消費量ノ點二 於テ著シキ差異き認メズ共二 $1 \mathrm{mg}$. 發有二要スル酸素量ハ1.2c.c.ト1.6c.c. ノ間ニアリ。

\section{第二項 培養試驗管,數卜呼吸商卜，關係}

今 $5 \%$ glycerol broth キ入レタル試驗管 1 本， 2 本， 5 本，10 本き用七テ人型結 核菌上池三代及ビ 牛型結核菌 No. 3 尹移植シ 3000 c.c. 乃至 3500 c.c. ，容量，Jar 中二 大氮ノ酸素分壓ノ下二培養シ 1 週間目， 2 週間目， 3 週間目ノ呼吸き測定シタル成績 八 Table V 及ビ Table VI 二揭示七リ。

Table V.

Analyses and quotients of human tubercle bacilli (Kamiike III) grown on glycerol broth.

\begin{tabular}{|c|c|c|c|c|}
\hline No. of experiment & I & II & III & IV \\
\hline $\begin{array}{l}\text { Experimental } \\
\text { material }\end{array}$ & Kamiike III & Kamiike III & Kamiike III & Kamiike III \\
\hline No. of tubes & 1 & 2 & 5 & 10 \\
\hline $\begin{array}{c}\begin{array}{c}\text { Net volume } \\
\text { of Jar }\end{array} \\
\end{array}$ & 3600 & 3580 & 3300 & 3200 \\
\hline $\begin{array}{r}\text { Analyses } \\
7 \text { days } \\
14 \text { days } \\
21 \text { days } \\
\end{array}$ & $\begin{array}{lc}\mathrm{CO}_{2} & \mathrm{O}_{2} \\
0.546 & 20.484 \\
1.463 & 19.464 \\
2.988 & 18.127 \\
\end{array}$ & $\begin{array}{cc}\mathrm{CO}_{2} & \mathrm{O}_{2} \\
0.927 & 20.350 \\
3.462 & 16.978 \\
5.983 & 14.559 \\
\end{array}$ & \begin{tabular}{rr}
$\mathrm{CO}_{2}$ & \multicolumn{1}{c}{$\mathrm{O}_{2}$} \\
2.779 & 18.742 \\
9.567 & 9.958 \\
14.198 & $\mathbf{3 . 6 8 1}$
\end{tabular} & \begin{tabular}{rr}
$\mathrm{CO}_{2}$ & \multicolumn{1}{c}{$\mathrm{O}_{\varepsilon}$} \\
3.639 & 16.790 \\
13.149 & 4.676 \\
15.166 & 1.901 \\
\end{tabular} \\
\hline $\begin{array}{r}\text { Quotients } \\
7 \text { days } \\
14 \text { days } \\
21 \text { days } \\
\end{array}$ & $\begin{array}{l}1.1570 \\
0.9775 \\
1.0736\end{array}$ & $\begin{array}{l}1.5460 \\
0.8684 \\
0.9343\end{array}$ & $\begin{array}{l}1.2560 \\
0.8692 \\
0.8213\end{array}$ & $\begin{array}{l}0.8609 \\
0.8071 \\
0.7999\end{array}$ \\
\hline $\begin{array}{l}\text { C. c. } \mathrm{O}_{2} \text { loss at } \\
\mathrm{O} \text { degree, } 760 \mathrm{~mm}\end{array}$ & 137 & 254 & 523 & 565 \\
\hline $\begin{array}{l}\text { Dry weight of } \\
\text { bacilli in mgs }\end{array}$ & 80 & 77. 80.5 & $\begin{array}{l}88.75 .81 .71 . \\
74\end{array}$ & $\begin{array}{l}40.42 .39 .40 .43 \\
38.45 .42 .41 .40\end{array}$ \\
\hline Average & 80 & 78.5 & 78 & 41 \\
\hline $\begin{array}{c}\text { Consumed } \mathrm{O}_{2} \\
\text { Dry weight of } \\
\text { bacilli }\end{array}$ & 1.8 & 1.7 & 1.4 & 1.5 \\
\hline
\end{tabular}

Table VI.

Analyșes and quotients of bovine tubercle bacilli (No. 3) grown on glycerol broth.

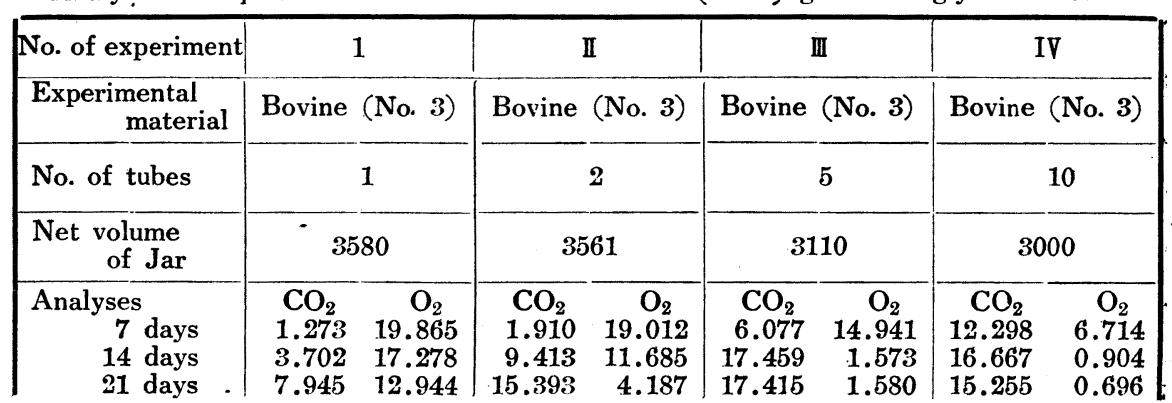




\begin{tabular}{|c|c|c|c|c|}
\hline $\begin{array}{r}\text { Quotients } \\
7 \text { days } \\
14 \text { days } \\
21 \text { days }\end{array}$ & $\begin{array}{l}1.1170 \\
1.0050 \\
0.9911\end{array}$ & $\begin{array}{l}0.9807 \\
1.0140 \\
0.9 .175\end{array}$ & $\begin{array}{l}1.0090 \\
0.9006 \\
0.8963\end{array}$ & $\begin{array}{l}0.8629 \\
0.8307 \\
0.7500\end{array}$ \\
\hline $\begin{array}{l}\text { C. c. } \mathrm{O}_{2} \text { loss at } \\
\mathrm{O} \text { degree, } 760 \mathrm{~mm}\end{array}$ & 273 & 538 & 534 & 537 \\
\hline $\begin{array}{l}\text { Dry weight of } \\
\text { bacilli in mgs }\end{array}$ & 141 & 140. 145 & $\begin{array}{l}80.81 .75 .76 . \\
72\end{array}$ & $\begin{array}{l}40.39 .45 .41 .42 \\
42.37 .39 .36 .41 \\
\end{array}$ \\
\hline Average & 141 & 142 & 77 & 40 \\
\hline 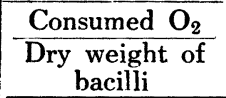 & 2 & 1.9 & 1.5 & 1.5 \\
\hline
\end{tabular}

Table V 八人型結核菌上池 III フ培養七ル實驗ナリ。Experiment I 八試驗管 1 本， 時ノ成績ニシテ 1 週間目，呼吸商郎 $₹$ R.Q. $=\frac{0.516}{0.446}=1.157,2$ 週間目， R.Q.= $\frac{1.433}{1.466}=0.9775,3$ 週間目， R.Q. $=\frac{2.958}{2.830}=1.0736+リ 。$ Experiment II 八 tube 2 本 場合，成績 =シテ 1 週間目， R.Q. $=\frac{0.897}{0.580}=1.546,2$ 週間目， R.Q. $=$ $\frac{3.432}{3.952}=0.8684,3$ 週間目， R.Q. $=\frac{5.953}{6.371}=0.9343+$ 驗管 5 本，時，成績ニシテ 1 週間目， R.Q. $=\frac{2.749}{2.188}=1.256,2$ 週間目， R.Q. = $\frac{9.537}{10.972}=0.8692,3$ 週間目〉 R,Q. $=\frac{14.168}{17.249}=0.8213$ ナリ。Experiment IV 八 10 本，時，成績ニシテ 1 週間目， R.Q. $=\frac{3.609}{4.140}=0.8609 ， 2$ 週間目， R.Q. $=$ $\frac{13.190}{16.259}=0.8071 ， 3$ 週間目， R.Q. $=\frac{15.136}{19.029}=0.7999$ ナリ。

Table VI. 八牛型結核菌 No. 3 キ培養セル實驗ナリ。Experiment I 八試驗管 1 本ノ時ノ成績ニシテ 1 週間目八 R.Q. $=\frac{1.243}{1.165}=1.117,2$ 週間目八 R.Q. $=\frac{3.672}{3.652}$ $=1.005,3$ 週間目八 R.Q. $=\frac{7.915}{7.980}=0.9911$ ナリ。Fxperiment II 八試驗管 2 本

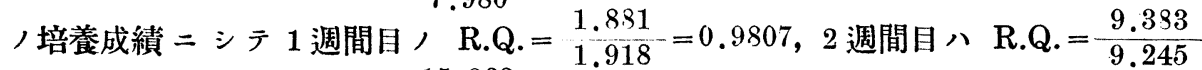
$=1.014,3$ 週間目八 R.Q. $=\frac{15.363}{16.743}=0.9175$ ナリ。Experiment III 八試驗管 5 本 ，培養成績 ニシテ 1 週間目， R.Q. $=\frac{6.047}{5.989}=1.009 ， 2$ 週間目， R.Q. $=\frac{17.429}{19.357}$ $=0.9006,3$ 週間目 / R.Q. $=\frac{17.385}{19.372} 0.8963$ ナリ。Experiment IV 八試驗管 10 本 ，培養成績ニシテ 1 週間目， R.Q. $=\frac{12.268}{14.216}=0.8629,2$ 週間目， R.Q. $=\frac{16.637}{20.026}$ $=0.8307,3$ 週間目, R.Q. $=\frac{15.225}{20.334}=0.7500$ ナリ。

今 3 週間目， R.Q. 于比較考察スルニ Table $\mathrm{V}$ ニ於テハ 1 本ノ時ハ $1.0736,2$ 本 八時八 $0.9343,5$ 本ノ時ハ $0.8213,10$ 本ノ時ハ 0.7999 二シテ Table VI ニ於テハ 1 本 ノ時八 $0.9911,2$ 本/時八 0.9175, こ本ノ時ハ $0.8963,10$ 本ノ時ハ 0.7500 ナリ。コ， 10 本 3 週間目ノR.Q. ，值ノ低キニ失スル理由八 Table VI，Experiment IV，表 
ノ如ク 2 週間目二 $=16.6 \%$ リタル $\mathrm{CO}_{2}$ 量ガ同一 Jar 二於テ 3 週間目 $=15.2 \%=$ 減 少セルキ見儿。之八明カ二CO:ガ培養液二吸收サレタルモ/ト思ハザルベカラズ。 今假リ $=2$ 週間目， $\mathrm{CO}_{2}$ 量 3 週間目， $\mathrm{CO}_{2}$ 量卜假定スル時八 3 週間目， R.Q. $=$ $\frac{16.637}{20.234}=0.8222$ トナル。

コノ實驗ニ於テ大體次，事き確言シテ差支へナカル可シ。郎チ glycerol ノ呼吸商 ノ理論的數值， 0.875 ナル故二今 3000 c.c. 乃至 3500 c.c. 容量，Jar 尹用七テ glycerol broth /試驗管ノ數キ 1 本乃至 2 本トシテ培養シタル時/呼吸商ハ少ナクトモ 3 週間 ノ培養成績ニテハ正確ナル値キ得ル事困難ナリ。 3 週間培養成績二テ比較的正確ナル 値キ得ントスルナラバ試驗管，數き 3 本乃至 5 本トセザル可カラズ。又10 本/試驗

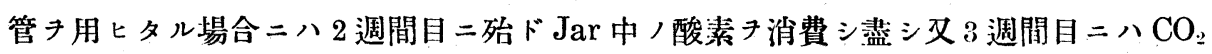
量ノ大ナル消失キ來タス事アル故二 2 週間目二測定シタル值キ以テ正確ナルモノト見 做シテ差支へナシ。

佾コノ實驗二於亏牛型結核菌 No. 31 本培養ノ 3 週間目/發育菌量ハ $136 \mathrm{mg}$. ニテ $1 \mathrm{mg}$. 發有二要スル酸素ハ 2 c.c.ナリ。 2 本ノ場合八發有菌量 1 本本均 $137 \mathrm{mg}$.ニテ $1 \mathrm{mg}$ ・ 發育二對三酸素消費量 $1.9 \mathrm{ccc}$, 5 本 / 場合ハ 1 本本均發有菌量 $72 \mathrm{mg}$. ニシテ $1 \mathrm{mg}$. 發 肓二要スル酸素量八 1.5 c.c. 10 本, 場合八墢南菌量 1 本本均 $35 \mathrm{mg}$. ニシテ $1 \mathrm{mg}$. 菌量 二對シ酸素消費量 1.5 c.c. ナリ。

又人型結核菌上池 III 1 本培養， 3 週間目ノ發育菌量八 $75 \mathrm{mg}$ ニシテ $1 \mathrm{mg}$. 發有菌 量二對シ酸素消費量 1.8 c.c. ナリ。 2 本ノ場合八發育菌量 1 本本均 $73 \mathrm{mg}$. ニシテ $1 \mathrm{mg}$. 菌量二對シ酸素消費量 $1.7 \mathrm{cc}+リ 。 又 5$ 本ノ時八發有菌量 1 本本均 $73 \mathrm{mg}$. ニシテ 1 mg. 菌量二對シ酸素消費量 1.4c.c. ナリ。又 10 本ノ場合 八發有菌量本均 1 本 $36 \mathrm{mg}$. 二 シテ $1 \mathrm{mg}$. 菌量發有二要スル酸素ハ 1.5 c.c. ナリ。郎于試驗管ノ數ノ增スト共 $=1 \mathrm{mg}$. 發育二要スル酸素量減少セルキ見ル。コノ實驗二於テモ人型結核菌及ビ牛型結核菌， 間二八呼吸商及ビ酸素消費量，點二於テ著明ナル差異き認メズ。酸素消費量ハ人型,

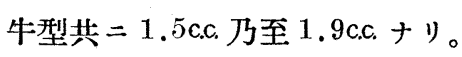

\section{第三項 水銀蒸氣ノ結核菌二及ボス影響}

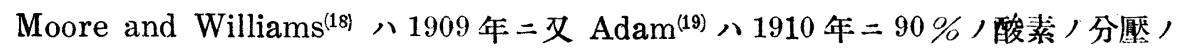
下二結核菌丹培養セントシテ失敗七ルニ反シ Novy 等ハ $98 \%$ /酸素ノ分壓ノ下 $=2$ 週乃至 3 週二シテ純白色二テ盛り上リテ發育セシムルコトニ成功セリ。Novy M Mo-

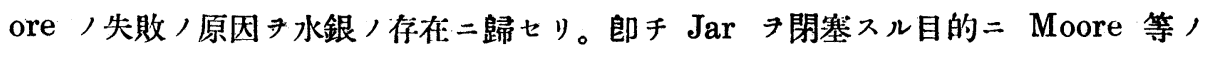
用ヒタル水銀封鎖ノ水銀ガ Jar / 中二過チテ漏洩シタル䉆メナラントノ異論キ唱フ。 
余八發育良好ノ牛型結核菌 No. 3 キ用七 $5 \%$ glycerol broth チ入レタル試驗管二移 植シ其ノ數き 1 本及ビ 5 本トシ Jar 中二密閉シテ大氣，酸素分涯，下二培養シ劣 Jar 八器底二水銀ノ 1 滴キ入レテ水銀蒸氣ノ結核菌ニ及ボス影響キ觀察セリ。ソノ實 驗成績ハ Table VII 二記載セリ。

Table VII.

Analyses of bovine tubercle bacilli (No. 3) grown on glycerol broth with a drop of mercury in the bottom of Jar.

\begin{tabular}{|c|c|c|c|c|}
\hline No. of experiment & \multicolumn{2}{|c|}{ I } & \multicolumn{2}{|c|}{ II } \\
\hline Experimental material & \multicolumn{2}{|c|}{ Bovine (No. 3) } & \multicolumn{2}{|c|}{ Bovine (No. 3) } \\
\hline No. of tubes & \multicolumn{2}{|c|}{1} & \multicolumn{2}{|c|}{5} \\
\hline Net volume of Jar & \multicolumn{2}{|c|}{3480} & \multicolumn{2}{|c|}{3400} \\
\hline $\begin{array}{r}7 \text { days } \\
14 \text { days } \\
21 \text { days } \\
26 \text { days } \\
\end{array}$ & $\begin{array}{l}\mathrm{CO}_{2} \\
0.47 \\
0.55 \\
0.588 \\
0.92\end{array}$ & $\begin{array}{r}\mathrm{O}_{2} \\
20.5 \\
20.3 \\
20.4 \\
19.8\end{array}$ & $\begin{array}{c}\mathrm{CO}_{2} \\
1.8 \\
2.9 \\
3.7 \\
3.1 \\
\end{array}$ & $\begin{array}{r}\mathrm{O}_{2} \\
19.3 \\
17.7 \\
17.1 \\
17.2 \\
\end{array}$ \\
\hline $\begin{array}{l}\text { Dry weight of bacilli } \\
\text { after } 4 \text { weeks. }\end{array}$ & \multicolumn{2}{|c|}{29} & \multicolumn{2}{|c|}{$\begin{array}{c}10.12 .10 .11 \\
8\end{array}$} \\
\hline
\end{tabular}

$$
\mathrm{CO}_{2}=0.03 \quad \mathrm{O}_{2}=20.93 \quad \mathrm{~N}_{2}=79.04
$$

Table VII 二見ル如 ク 1 本培養，モ，八 1 週間目 $=\mathrm{CO}_{2}=0.47$ $\%, \mathrm{O}_{2}=20.5 \%, 2$ 週 間目 $=\mathrm{CO}_{2}=0.55 \%$ ， $\mathrm{O}_{2}=20.3 \%, 3$ 週間目 $=\mathrm{CO}_{2}=0.588 \%, \mathrm{O}_{2}=$ $20.4 \%$ ニシテ 4 週間目 二至ルモ份 $\mathrm{CO}_{2}=0.92$ $\%, \mathrm{O}^{2}=19.8 \%$ ニシテ 第二項 實驗二於テ 3

週間目ニ $136 \mathrm{mg}$ ノ發有菌量キ得タルニ反シ本實驗ニ於テ 八發有菌量僅カニ $24 \mathrm{mg}=$ シテ酸素消費量 モ 前實驗二於テハ $273 \mathrm{ccc}$. ノモノガ本實驗ニテハ $47 \mathrm{ccc}$ ナリリ。 5 本ノ 培養，成績八 1 週間目 $=\mathrm{CO}^{2}=1.80 \%, \mathrm{O}_{2}=19.3 \%, 2$ 週間目 $=\mathrm{CO}_{2}=2.9 \%, \mathrm{O}_{2}=$ $17.7 \%, 3$ 週間目二至ルモ $\mathrm{CO}_{2}=3.7 \%, \mathrm{O}_{2}=17.1 \%$ リ。而シテ第二項，實驗二於テ 八 1 本本均,發育菌量ハ 3 週間目= $72 \mathrm{mg}$ アリタルモノガ本實驗ニテハ僅カニ $5 \mathrm{mg}$

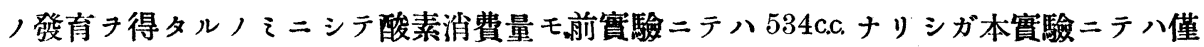
カニ138c.c. ナリ。加之本實驗ニテ八硫化水銀ノ形成ノ䉆メ二結核菌八黑褐色き呈ス。

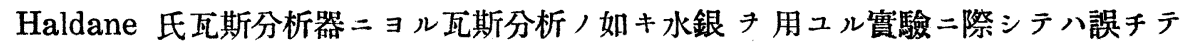
Jar 中二水銀キ漏洩スル事ナシトセズ。斯ノ如キ場合實驗ニ及ボス影㗽甚大ナルモノ ナレバ實驗二際シ水銀ノ取扱ヒニ細心ノ注意き要スルモノト思惟ス。

\section{第二節 種々ナル抗酸性菌ノ呼吸商二就テ}

實驗材料トシテ八人型結核菌 3 種 (青山 B. 上池 目. 松本)牛型結核菌五種(No. 3 , No. 6, No. 12, No. 14, 北研) 及ビ B.C.G., timothy 菌, 鳥型結核菌, 11 種キ選ビ $5 \%$ glycerol broth 二移植シテ大氧，酸素壓，下二Jar 中二培養シ前節，實驗二䖪 そ 容量 $3000 \mathrm{ccc}$. 乃至 $3500 \mathrm{ccc}$. J Jar キ用ヒタル時八試驗管ノ數 7.3 本乃至 5 本トシテ3 
週間目二, 又同樣容量, Jar $=10$ 本ノ試驗管タ用ヒタル時ハ 2 週間目二瓦斯分析タ 行七又容量 1000 c.c. 乃至 1500 c.c. J Jar キ用七タル時八試養管ノ數キ 2 本トシテ 3 週 間目二瓦斯分析キ行ヒテ呼吸商キ測定比較セリ。ソノ實驗成績ハ Table VIII 乃至 Table XI 二揭示セり。

Table VIII.

Analyses and quotients of human tubercle bacilli grown on glycerol broth.

\begin{tabular}{|c|c|c|c|}
\hline No. of experiment & I & II & III \\
\hline Experimental material & Aoyama B & Kamiike III & Matsumoto \\
\hline No. of days & 14 & 21 & 21 \\
\hline No. of tubes & 10 & 5 & 2 \\
\hline Net volume of Jar & 3400 & 3300 & 1960 \\
\hline Manometer & -1.0 & -60 & -55 \\
\hline $\begin{array}{cl}\text { Barometer } & \\
& \text { Initial } \\
& \text { Final } \\
\end{array}$ & $\begin{array}{l}757.6 \\
759.3 \\
\end{array}$ & $\begin{array}{l}757.6 \\
756\end{array}$ & $\begin{array}{l}747.3 \\
754\end{array}$ \\
\hline $\begin{array}{c}\text { Temperature } \\
\text { Initial } \\
\text { Final } \\
\end{array}$ & $\begin{array}{l}23 \\
28\end{array}$ & $\begin{array}{l}23 \\
29\end{array}$ & $\begin{array}{l}22.5 \\
25\end{array}$ \\
\hline $\begin{array}{ll}\text { Analyses } & \\
& \mathrm{CO}_{2} \\
& \mathrm{O}_{2} \\
& \mathrm{~N}_{2}\end{array}$ & $\begin{array}{r}13.998 \\
4.427 \\
81.575 \\
100.000 \\
\end{array}$ & $\begin{array}{r}14.645 \\
3.797 \\
81.558 \\
100.000\end{array}$ & $\begin{array}{r}18.380 \\
0.281 \\
81.339 \\
100.000\end{array}$ \\
\hline $\begin{array}{l}\text { Corr. analyses } \\
\qquad \begin{array}{r}\mathrm{CO}_{2} \\
\mathrm{O}_{2} \\
\mathrm{~N}_{2}\end{array}\end{array}$ & $\begin{array}{r}13.563 \\
4.288 \\
79.040 \\
96.891 \\
\end{array}$ & $\begin{array}{r}14.198 \\
3.681 \\
79.040 \\
96.919 \\
\end{array}$ & $\begin{array}{r}17.860 \\
0.273 \\
79.040 \\
97.173\end{array}$ \\
\hline $\begin{array}{cl}\text { Quotiens } & \\
& \text { Apparent resp. } \\
\text { Real resp. } \\
\mathrm{N}_{2} \\
\end{array}$ & $\begin{array}{l}0.8463 \\
0.8131 \\
0.9689 \\
\end{array}$ & $\begin{array}{l}0.8530 \\
0.8213 \\
0.9694 \\
\end{array}$ & $\begin{array}{l}0.8854 \\
0.8631 \\
0.9717 \\
\end{array}$ \\
\hline
\end{tabular}

Table VIII 八人型結核菌青山 B, 上池 III，松本ノ呼吸商キ示ス。Experiment I 八 青山 B. $尹 3400 \mathrm{ccc}$ ，容量，Jar 中二試驗管，數キ10 本トシテ培養シテ 2 週間目二瓦 斯分析チ行ヒタル成績ナリ。郎チ 2 週間目二 manometer ハー $10 \mathrm{~mm}$ キ示シ $\mathrm{CO}_{2}$ 量八 $13.998 \% ， \mathrm{O}_{2}$ 量ハ $4.427 \%$ シテ表面上儿呼吸商ハ 0.8463 ナリ。而シテ窒素係數八 $\frac{79.040}{81.575}=0.9689$ ナル故二分析ノ結果修正スル時ハ $\mathrm{CO}_{2}$ 量ハ $13.563 \%, \mathrm{O}_{2}$ 量八 $4.288 \%$ ニシテ真, 呼吸商ハ 0.8131 ナリ。

Experiment II 八上池 III $* 3300$ c.c. /容量/Jar 中二試驗管 / 數 5 本トシテ培 養 3 週間目二瓦斯分析き行ヒタル成績ニシテ 3 週間目二 manometer ハ $-60 \mathrm{~mm}$ ‡ 示シ $\mathrm{CO}_{2}$ 量八 $14.645 \%, \mathrm{O}_{2}$ 量ハ $3.797 \%$ ニテ表面上ノ呼吸商ハ 0.8530 ナリ。咥 
素係數ハ $\frac{79.040}{81.558}=0.9694$ ナルチ以テ修正スル時ハ $\mathrm{CO}_{2}$ 量ハ $14.198 \% ， \mathrm{O}_{2}$ 量 $3.681 \%$ \%キ以テ葚ノ呼吸商ハ 0.8213 ナリ。

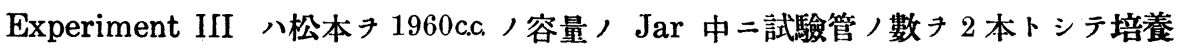
3 週間目二瓦斯分析キ行ヒタル成績ナリ。郎チ 3 週間目二 manometer ハ $-55 \mathrm{~mm}$ タ 示シ $\mathrm{CO}_{2}$ 量 $18.380 \%, \mathrm{O}_{2}$ 量ハ $0.281 \%$ シテ表面上ノ呼吸商ハ 0.8854 ナリ。而 テ窒素係數ハ $\frac{79.040}{81.339}=0.9717$ ナル故二分析ノ結果修正入ル時ハ $\mathrm{CO}_{2}$ 量ハ 17.860 $\%, \mathrm{O}_{2}$ 量ハ $0.273 \%$ ル故二畺, 呼吸商ハ 0.8631 ナリ。

Table IX.

Analyses and quotients of bovine tubercle bacilli grown on glycerol broth.

\begin{tabular}{|c|c|c|c|}
\hline No. of experiment & I & II & III \\
\hline Experimental material & Bovine (No. 3) & Bovine (No. 6) & Bovine (No. 12) \\
\hline No. of days & 14 & 14 & 21 \\
\hline No. of tubes & 10 & 10 & 2 \\
\hline Net volume of Jar & 3000 & 3000 & 1990 \\
\hline Manometer & -26 & -22 & -53 \\
\hline $\begin{array}{ll}\text { Barometer } & \\
& \text { Initial } \\
& \text { Final } \\
\end{array}$ & $\begin{array}{l}760 \\
755.1\end{array}$ & $\begin{array}{l}760.1 \\
759.1\end{array}$ & $\begin{array}{l}747.3 \\
754 \\
\end{array}$ \\
\hline $\begin{array}{l}\text { Temperature } \\
\qquad \begin{array}{l}\text { Initial } \\
\text { Final }\end{array}\end{array}$ & $\begin{array}{l}26 \\
30\end{array}$ & $\begin{array}{l}18.5 \\
22\end{array}$ & $\begin{array}{l}22.5 \\
25\end{array}$ \\
\hline $\begin{array}{ll}\text { Analyses } & \\
& \mathrm{CO}_{2} \\
& \mathrm{O}_{2} \\
& \mathrm{~N}_{2}\end{array}$ & $\begin{array}{r}17.256 \\
0.935 \\
81.819 \\
100.000\end{array}$ & $\begin{array}{r}17.569 \\
0.536 \\
81.905 \\
100.000\end{array}$ & $\begin{array}{r}16.228 \\
3.141 \\
80.631 \\
100.000 \\
\end{array}$ \\
\hline $\begin{array}{r}\text { Corr. analyses } \\
\mathrm{CO}_{2} \\
\mathrm{O}_{2} \\
\mathrm{~N}_{2}\end{array}$ & $\begin{array}{r}16.667 \\
0.904 \\
79.040 \\
96.611 \\
\end{array}$ & $\begin{array}{r}16.956 \\
0.517 \\
79.040 \\
96.513 \\
\end{array}$ & $\begin{array}{r}16.006 \\
3.078 \\
79.040 \\
98.124 \\
\end{array}$ \\
\hline $\begin{array}{l}\text { Quotients } \\
\text { Apparent resp. } \\
\text { Real resp. } \\
\mathrm{N}_{2} \\
\end{array}$ & $\begin{array}{l}0.8615 \\
0.8307 \\
0.9661 \\
\end{array}$ & $\begin{array}{l}0.8600 \\
0.8291 \\
0.9651 \\
\end{array}$ & $\begin{array}{l}0.9105 \\
0.8949 \\
0.9802 \\
\end{array}$ \\
\hline
\end{tabular}

Table IX, 八牛型結核菌 No. 3 , No. 6 , No. 12 ，呼吸商キ示ス。Experiment I 八牛型結核菌 No. 3 丹 3000 c.c. 容量, Jar 中二試驗管ノ數 10 本トシテ培養シ 2 週 間目二瓦斯分析キ行ヒタル成績ニシテ郎チ 2 䓢間目 = manometer $ハ-26 \mathrm{~mm}$ キ示 シ $\mathrm{CO}_{2}$ 量ハ $17.256 \%, \mathrm{O}_{2}$ 量 $0.935 \%$ ニテ表面上/呼吸商ハ 0.8615 ナリ。而シ テ窒素係數 $=\frac{79.040}{81.819}=0.9661$ ナルキ以テ分析ノ結果 修正 スル時ハ $\mathrm{CO}_{2}$ 量ハ $16.667 \%, \mathrm{O}_{2}$ 量ハ $0.904 \%$ ルキ以テ真/呼吸商ハ 0.8307 ナリ Experiment II ハ 
牛型結核菌 No. 6 キ容量 3000 c.c. J Jar 二試驗管 /數キ 10 本トシテ培養シ 2 週間目二 瓦斯分析キ行ヒタル成績ニシテ 2 週間目 $=$ manometer ハ $-22 \mathrm{~mm}$ チ示シ $\mathrm{CO}_{2}$ 量 八 $17.569 \%, \mathrm{O}_{2}$ 量八 $0.536 \%$ ニテ表面上ノ呼吸商ハ 0.8600 ナリ。而シテ窒素係 數 $=\frac{79.040}{81.905}=0.9651$ ナルキ以テ修正スル時ハ $\mathrm{CO}_{2}$ 量ハ $16.956 \%, \mathrm{O}_{2}$ 量ハ $0.517 \%$ ニシテ真八呼吸商ハ 0.8291 ナリ Experiment III 八牛型結核菌 No. 12 チ容量 1990 c.c.，Jar 中二試驗管ノ數み 2 本トシテ培養シ 3 週間目二瓦斯分析 タ行ヒタル成績二 シテ 3 週間目二 manometer ハ $-53 \mathrm{~mm}$ キ示シ $\mathrm{CO}^{2}$ 量ハ $16.228 \%, \mathrm{O}_{2}$ 量ハ 3.141

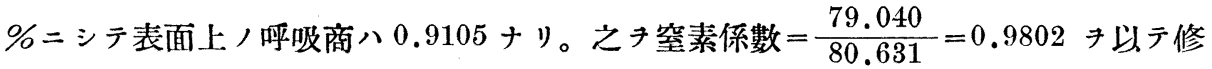
正スル時八 $\mathrm{CO} 2$ 量八 $16.006 \%, \mathrm{O}_{2}$ 量ハ $3.078 \%$ ニテ葚, 呼吸商八 0.8949 ナリ。

Table X.

Analyses and quotients of bovine tubercle becilli and B.C.G. grown on glycerol broth.

\begin{tabular}{|c|c|c|c|}
\hline No. of experiment & $\mathrm{I}$ & II & III \\
\hline Experimental material & Bovine (No. 14) & Bovine (Hokken $)$ & B.C.G. \\
\hline No. of days & 21 & 21 & 21 \\
\hline No. of tubes & 2 & 3 & 3 \\
\hline Net volume of Jar & 1590 & 3540 & 3340 \\
\hline Manometer & -52 & -52 & -48 \\
\hline $\begin{array}{ll}\text { Barometer } & \\
& \text { Initial } \\
& \text { Final }\end{array}$ & $\begin{array}{l}763.7 \\
759.4 \\
\end{array}$ & $\begin{array}{l}755.6^{\circ} \\
756.5\end{array}$ & $\begin{array}{l}756.2 \\
755.6\end{array}$ \\
\hline $\begin{array}{r}\text { Temperature } \\
\text { Initial } \\
\text { Final } \\
\end{array}$ & $\begin{array}{l}20 \\
24 \\
\end{array}$ & $\begin{array}{l}22 \\
19\end{array}$ & $\begin{array}{l}23 \\
22\end{array}$ \\
\hline $\begin{array}{lr}\text { Analyses } & \mathrm{CO}_{2} \\
& \mathrm{O}_{2} \\
& \mathrm{~N}_{2}\end{array}$ & $\begin{array}{r}16.896 \\
1.410 \\
81.694 \\
100.000\end{array}$ & $\begin{array}{r}17.757 \\
0.424 \\
81.819 \\
100.000\end{array}$ & $\begin{array}{r}17.627 \\
0.274 \\
82.099 \\
100.000\end{array}$ \\
\hline $\begin{array}{r}\text { Corr. analyses } \\
\mathrm{CO}_{2} \\
\mathrm{O}_{2} \\
\mathrm{~N}_{2}\end{array}$ & $\begin{array}{r}16.325 \\
1.361 \\
79.040 \\
96.726 \\
\end{array}$ & $\begin{array}{r}17.153 \\
0.254 \\
79.040 \\
96.447\end{array}$ & $\begin{array}{r}16.971 \\
0.263 \\
79.040 \\
96.274\end{array}$ \\
\hline $\begin{array}{l}\text { Quotients } \\
\text { Apparent resp. } \\
\text { Real resp. } \\
\mathrm{N}_{2} \\
\end{array}$ & $\begin{array}{l}0.8640 \\
0.8326 \\
0.9662 \\
\end{array}$ & $\begin{array}{l}0.8644 \\
0.8281 \\
0.9660 \\
\end{array}$ & $\begin{array}{l}0.8519 \\
0.8197 \\
0.9628 \\
\end{array}$ \\
\hline
\end{tabular}

Table X. 八牛型結核菌 No. 14 及ビ北研及ピ B.C.G /呼吸商キ示ス。 Experiment I 八牛型結核菌 No. 14 丹 1590 c.c. / 容量/Jar 中二試驗管/數き 2 本トシテ培 養 3 週間目二瓦斯分析 行ヒタル成績ニシテ 3 週間目二 manometer ハ $-52 \mathrm{~mm}$ \% 示シ $\mathrm{CO}_{2}$ 量ハ $16.896 \%, \mathrm{O}_{2}$ 量ハ $1.410 \%$ シテ表面上，呼呢商ハ 0.8640 ナリ。窒 
素係數 $=\frac{79.040}{81.694}=0.9662$ ナルキ以テ分析ノ結果キ修正スル時ハ $\mathrm{CO}_{2}$ 量ハ 16.325 $\%, \mathrm{O}_{2}$ 量八 $1.361 \%$ ニテ真，呼吸商八 0.8326 ナリ。

Experiment II 八北研牛型菌尹 3540 c.c. /容量ノJar 中二試驗管 數キ 3 本トシ テ培養シ 3 週間目二瓦斯分析テ行ヒタル成績ニシテ 3 週間目二 manometer ハー52 $\mathrm{mm}$ チ示シ $\mathrm{CO}_{2}$ 量八 $17.757 \%, \mathrm{O}_{2}$ 量ハ $0.424 \%$ シテ表面上/呼吸商ハ 0.8644 ナリ。而シテ窒素係數 $=\frac{79.040}{81.819}=0.9660$ キ以テ修正スル時ハ $\mathrm{CO}_{2}$ 量ハ $17.153 \%$, $\mathrm{O}_{2}$ 量ハ $0.254 \%$ ニテ宍, 呼吸商ハ 0.8281 ナリ。

Experiment III ハ B.C.G. $尹 3340$ c.c. ノ容量ノJar 中二試驗管ノ數 33 本トシテ 培養シ 3 週間目二瓦斯分析チ行ヒタル成績ニシテ 3 週間目二 manometer チ示シ $\mathrm{CO}_{2}$ 量ハ $17.627 \%, \mathrm{O}_{2}$ 量ハ $0.274 \%$ ニテ表面上/呼吸商ハ 0.8519 ナリ。 而シテ窒素係數 $=\frac{79.040}{82.099}=0.9628$ ナルキ以テ修正スル時ハ $\mathrm{CO}_{2}$ 量ハ $16.971 \%$, 量ハ $0.263 \%$ シテ眞ノ呼吸商ハ 0.8197 ナリ。

Table XI.

Analyses and quotients of avian tubercle bacilli and timothy bacilli grown on glycerol brath.

\begin{tabular}{|c|c|c|}
\hline No. of experiment & I & II \\
\hline Experimental material & avian type & timothy \\
\hline No. of days & 21 & 21 \\
\hline No. of tubes & 2 & 3 \\
\hline Net volume of Jar & 1590 & 3540 \\
\hline Manometer & -47 & -48 \\
\hline $\begin{array}{ll}\text { Barometer } & \\
& \begin{array}{l}\text { Initial } \\
\text { Final }\end{array} \\
\end{array}$ & $\begin{array}{l}745.8 \\
749.5 \\
\end{array}$ & $\begin{array}{l}756.2 \\
755.6 \\
\end{array}$ \\
\hline $\begin{array}{r}\text { Temperature } \\
\text { Initial } \\
\text { Final }\end{array}$ & $\begin{array}{l}23 \\
25\end{array}$ & $\begin{array}{l}23 \\
22\end{array}$ \\
\hline $\begin{array}{lc}\text { Analyses } & \\
& \mathrm{CO}_{2} \\
& \mathrm{O}_{2} \\
& \mathrm{~N}_{2}\end{array}$ & $\begin{array}{c}18.036 \\
0.0 \\
81.964 \\
100.000 \\
\end{array}$ & $\begin{array}{r}17.924 \\
0.719 \\
81.357 \\
100.000 \\
\end{array}$ \\
\hline $\begin{array}{r}\text { Corr. analyses } \\
\qquad \mathrm{CO}_{2} \\
\mathrm{O}_{2} \\
\mathrm{~N}_{2}\end{array}$ & $\begin{array}{c}17.392 \\
0.0 \\
79.040 \\
96.432 \\
\end{array}$ & $\begin{array}{r}17.413 \\
0.698 \\
79.040 \\
97.151 \\
\end{array}$ \\
\hline $\begin{array}{l}\text { Quotients } \\
\text { Apparent resp. } \\
\text { Real resp. } \\
\mathrm{N}_{2} \\
\end{array}$ & $\begin{array}{l}0.8602 \\
0.8295 \\
0.9643 \\
\end{array}$ & $\begin{array}{l}0.8853 \\
0.8591 \\
0.9715 \\
\end{array}$ \\
\hline
\end{tabular}

Table XI i timothy 菌卜 鳥型結核菌，呼吸商 Experiment I 八鳥型結核菌 1590c.c.容量，Jar 中二試驗管， 數き 2 本トシテ培養シタル成績 ニシテ 3 週間目二 manometer 八 $-47 \mathrm{~mm}$ キ示シ $\mathrm{CO}_{2}$ 量ハ $18.036 \%, \mathrm{O}_{2}$ 量ハ $0 \%$ ニテ表 面上, 呼吸商八 0.8602 ナリ。 窒素係數 $=\frac{79.040}{81.964}=0.9643$ ヲ以テ修正ス儿時八 $\mathrm{CO}_{2}$ 量八 $17.392 \%, \mathrm{O}_{2}$ 量ハ $0 \%$ ル故二 眞, 呼吸商ハ 0.8295 ナリ。

Experiment II 八 timothy 菌尹 3540 c.c. ノ容量, Jar 中二 試驗管ノ數き 3 本トシテ培養セ ル成績ニシテ 3 週間目 ニシテ. manometer ハ $-48 \mathrm{~mm}$ キ示シ $\mathrm{CO}_{2}$ 量八 $17.924 \%, \mathrm{O}_{2}$ 量八 
$0.719 \%$ ニテ表面上ノ呼吸商ハ $0.8853+リ 。$

窒素係數 $=\frac{79.040}{81.357}=0.9715$ ナルキ以テ修正スル時ハ $\mathrm{CO}_{2}$ 量 $17.413 \%, \mathrm{O}_{2}$ 量八 $0.698 \%$ ル故二畺ノ呼吸商ハ0.8591ナリ。

以上各種，抗酸性菌ノ真ノ呼吸商キ一括シテ表示スレバ Table XII ノ如シ。

Table XII.

Quotients of the different kind of acid-fast bacilli grown on glycerol broth.

\begin{tabular}{|l|c|c|}
\hline \multicolumn{1}{|c|}{ Experimental material } & $\begin{array}{c}\text { Real respiratory } \\
\text { quotients }\end{array}$ & Average \\
\hline Huhman tubercle bacilli(Aoyama B.) & 0.8183 \\
\hline Huhman tubercle bacilli(Kamiike III) & 0.8213 \\
\hline Huhman tubercle bacilli(Matsumoto) & 0.8631 \\
\hline Bovine tubercle bacilli(No. 3) & 0.8307 \\
\hline Bovine tubercle bacilli(No. 6) & 0.8291 \\
\hline Bovine tubercle bacilli(No. 12) & 0.8949 \\
\hline Bovine tubercle bacilli(No. 14) & 0.8326 \\
\hline Bovine tubercle bacilli(Hokken) & 0.8281 \\
\hline B.C.G. & 0.8197 & 0.8431 \\
\hline Avian tubercle bacilli & 0.8295 & 0.8197 \\
\hline Timothy bacilli & 0.8591 & 0.8295 \\
\hline
\end{tabular}

Table XII 二見ル如ク人型結核菌/呼吸商ハ 0.8131 乃至 0.8631 ニシテ平均 0.8342 ナリ。牛型結核菌/呼吸商八 0.8281 乃至 0.8949 ニシテ本均 0.8431 ナリ。B.C.G.， 呼吸商八 0.8197 , 鳥型結核菌八 0.8295 , timothy 菌ハ 0.8591 二シテ各種/菌種ノ間 二大ナル差異キ認メズ。人型菌, 牛型菌, 鳥型菌各種ノ結核菌/真ノ呼吸商,本均値 キ求ムレバ 0.8356 ナリ。今 100 c.c., $\mathrm{CO}_{2}$ ガ生ジタト假定シ 0.8356 八呼吸商子與つ ル䉆メニハ $\mathrm{O}_{2} \neq \frac{100 \text { c.c. }}{0.8356}=119$ c.c. 消費セザル可カラズ。又 100 c.c. ., $\mathrm{CO}_{2}$ ガ生ジタト 假定シ呼吸商ノ理論的數値 0.857 ナル數キ與フル篇メニハ $\mathrm{O}_{2} \neq \frac{100 \mathrm{ccc}}{0.857}=116 \mathrm{c.c}$. 消費セザル可カラズ。而シテソノ差ハ 11.9c.c.-116c.c. =3c.c. ニシテ Jar /容量キ1000c.c. トシテモソノ誤差ハ $0.3 \%$ 故二 0.8356 ナル數ハ正確ナル數ト見テ差支へナシ。而 シテ Novy ガ glycerol agar キ以テ人型結核菌ノ呼吸商キ測定シタル値ハ $0.836=$ テ大體合致ス。

\section{第三節 種々ナル抗酸性菌ノ發育菌量及ビ酸素消費量二就テ}

\section{第一項 酸素ノ高分厔二於ケル實驗}

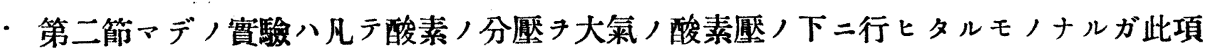
ニテハ酸素ノ分厚き增加シ $40 \%, 60 \%, 80 \%$ トシテ種々ナル抗酸性菌ノ酸素ノ需要量 及ビ發有菌量き測定セリ。而シテ Jar ノ中二酸素タ滿タス方法ハJar キ一度真空卜 
ナシタル後水槽ニ取リ入レタル酸素き逆二吸引シテ所胵ノ濃度二相當スル酸素量き 入レタル後 manometer , zero ニナルマデ窒素 ほ以テ滿タセリ。ソノ實驗成績ハ

\section{Table XIII.}

Analyses and oxygen requirement of human tubercle bacilli (Aoyama B.) grown on glycerol broth in the increased oxygen tension.

\begin{tabular}{|c|c|c|c|c|}
\hline No. of experiment & $\mathbf{I}$ & II & III & IV \\
\hline Planned percent. of oxygen & 20 & 40 & 60 & 80 \\
\hline Experimental material & Aoyama B. & Aoyama B. & Aoyama B. & Aoyama B. \\
\hline No. of days & 21 & 21 & 21 & 21 \\
\hline No. of tubes & 1 & 1 & 1 & 1 \\
\hline Net volume of Jar & 1610 & 3480 & 3580 & 3580 \\
\hline Manometer & -68 & -22 & -54 & -50 \\
\hline $\begin{array}{ll}\text { Barometer } & \\
& \begin{array}{l}\text { Initial } \\
\text { Final }\end{array}\end{array}$ & $\begin{array}{l}761.1 \\
760.7\end{array}$ & $\begin{array}{l}760 \\
762.6\end{array}$ & $\begin{array}{l}759 \\
765.6\end{array}$ & $\begin{array}{l}747.4 \\
751.4 \\
\end{array}$ \\
\hline $\begin{array}{c}\text { Temperature } \\
\text { Initial } \\
\text { Final } \\
\end{array}$ & $\begin{array}{l}21 \\
20\end{array}$ & $\begin{array}{l}17.5 \\
20\end{array}$ & $\begin{array}{l}25 \\
20\end{array}$ & $\begin{array}{l}22 \\
18\end{array}$ \\
\hline $\begin{array}{ll}\text { Analyses } & \\
& \text { Initial } \mathrm{O}_{2} \\
& \text { Final } \mathrm{O}_{2} \\
\end{array}$ & $\begin{array}{r}20.930 \\
6.283\end{array}$ & $\begin{array}{l}44.300 \\
40.055\end{array}$ & $\begin{array}{l}65.681 \\
59.337\end{array}$ & $\begin{array}{l}83.840 \\
83.251\end{array}$ \\
\hline $\begin{array}{ll}\text { C.c. } \mathrm{O}_{2} \text { at } & \mathrm{O} \text { degree, } \\
760 \mathrm{~mm} & \\
& \text { Initial } \\
& \text { Final }\end{array}$ & $\begin{array}{r}309 \\
84\end{array}$ & $\begin{array}{l}1366 \\
1231\end{array}$ & $\begin{array}{l}2073 \\
1784 \\
\end{array}$ & $\begin{array}{l}2658 \\
2512 \\
\end{array}$ \\
\hline $\mathrm{O}_{2}$ loss & 225 & 135 & 289 & 146 \\
\hline $\begin{array}{l}\text { Dry weight of bacilli in } \\
\text { mgs }\end{array}$ & 145 & 149 & 108 & 55 \\
\hline$\frac{\text { Consumed } \mathrm{O}_{2}}{\text { Dry weight of bacilli }}$ & 1.6 & 0.9 & 2.7 & 2.9 \\
\hline
\end{tabular}

Chart 5.

The growth and consumed oxygen curve of human tubercle bacilli(Aoyama B.)grown on glycerol broth in increased oxygen tension.

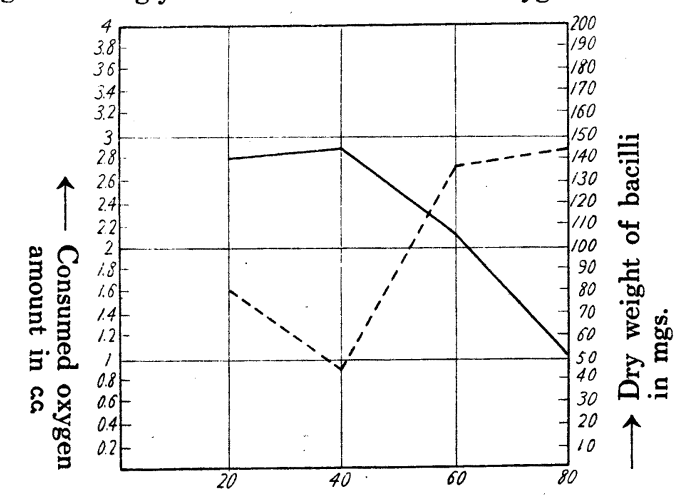

$\longrightarrow$ Percentage of oxygen.

Growth curve. 
Table XIII 乃至 Table XXIII 二揭示セリ。

Table XIII 八人型結核菌青山B. $940 \%$ 乃至 $80 \%$ 酸素分厘ノ下二培養シタル成 績ニシテ便宜上 $20 \%$ /酸素分壓ノ下ニナシタル實驗モ揭示七リ。

Experiment I ハ1610c.c. ノ容量ノJar キ用七 glycerol broth /試驗管ノ數 1 本トシテ 3 週間培養セル成績ニシテ最後二 manometer ハ $-68 \mathrm{~mm}$ キ示シ最初 20.93 \%郋チ 309 c.c. アリタル酸素ハ最後二6.283\%郎チ 84 c.c. トナリ酸素ノ消費量ハ 225 c.c. ニシテ 3 週間後, 藏量ハ $140 \mathrm{mg}$. ナル故 $=1 \mathrm{mg}$. 發育二要 スル酸素消費量ハ $1.6 \mathrm{ccc}$. ナリ。

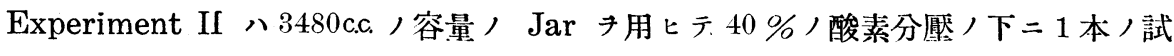
驗管き 3 週間培養セル成績ニシテ最後二 manometer ハ $-22 \mathrm{~mm}$ キ示シ最初 $44.3 \%$ 郎チ 1366 c.c. アリタル酸素ハ最後二 $40.055 \%$ 郎チ 1231 c.c. トナリ消費量ハ $135 c .6$ ニ テ菌量ハ $144 \mathrm{mg}$ ナル故 $=1 \mathrm{mg}$ 發育二要スル酸素量ハ $0.9 \mathrm{ccc}$. リ。

Experiment III. ハ 3580 c.c. ノ容量, Jar キ用七 $60 \%$ /酸素分厴ノ下二 1 本ノ試驗 管キ 3 週間培養七ル成績ニシテ最後ニ manometer ハ $-54 \mathrm{~mm}$ キ示シ最初 $65.681 \%$ 郎チ 2073 c.c. アリタル酸素 ハ最後二 $59.337 \%$ 郎チ 1784 c.c.トナリ消費量ハ 289 c.c. ニシ テ發育菌量ハ $103 \mathrm{mg}$ ナル故二 $1 \mathrm{mg}$ 發育二要スル酸素量ハ 2.7 c.c.ナリ。

Experiment IV ハ $3580 \mathrm{ccc}$ ，容量 ノJar 用七 $80 \%$ /酸素分壓ノ下二 1 本ノ試驗 管き培養セル成績ニシテ 3 週後 manometer 八 $-50 \mathrm{~mm}$ キ示シ最初 $83.84 \%$ 郎チ 2658 c.c. アリタル酸素八最後二 $83.251 \%$ 郎チ 2512 c.c. トナリ消費量ハ 146 c.c.ナリ。而シ テ發有菌量ハ $50 \mathrm{mg}$ ナル故二 $1 \mathrm{mg}$ 發育二要スル酸素量ハ $2.9 \mathrm{ccc}$. リ 。

今コノ發有菌量及ビ酸素消費量ノ關係き curve ニテ表ハス時ハ Chart 5 /如シ。 實線八菌量ノ發有チ示シタル curve ニシテ右側ニ mg. キ以テソ/數キ表ハ七リ。 又點線ハ菌量き以テ酸素消費量き除シタル數郎チ $1 \mathrm{mg}$.發育二要スル酸素量キ示シタ ル curve ニシテ左側ニc.c.キ以テソノ數キ表ハセリ。

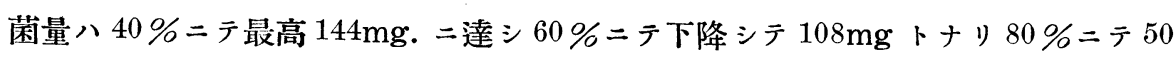
mg. =低下ス。但シコレ等ノ數八最初ノ移植菌量 $5 \mathrm{mg}$ キ減ジタル數ナリ。又酸素消 費量, curve八菌量ノ發育キ示入 curve 卜正反對ノ動キキ示シ $40 \%$ ニテ低下シ 0.9 c.c. トナリ $60 \%$ 二テ上昇シテ 2.7 c.c.トナリ $80 \%$ ニ最高 2.9 c.c. 二達ス。

Table XIV 八人型結核菌上池田 $40 \%$ 乃至 $80 \%$ 酸素分壓,下二培養七ル成績ナ リ。Experiment I ハ3600c.c. 八容量, Jar キ用七 $20 \%$ / 酸素分壓,下 $=$ glycerol broth，試驗管き 1 本培養セル成績ニシテ 3 週後 manometer ハ $-50 \mathrm{~mm}$ キ示シ最 
Table XIV.

Analyses and oxygen requirement of human tubercle bacilli (Kamiike III) grown on glycerol broth in increased oxygen tension.

\begin{tabular}{|c|c|c|c|c|}
\hline No. of experiment & $\mathbf{I}$ & II & III & IV \\
\hline Planned percent. of oxygen & 20 & 40 & 60 & 80 \\
\hline Experimental material & Kamiike III & Kamiike III & Kamiike III & Kamiike III \\
\hline No. of days & 21 & 21 & 21 & 21 \\
\hline No. of tubes & 1 & 2 & 1 & 1 \\
\hline Net volume of Jar & 3600 & 3580 & 3580 & 3480 \\
\hline Manometer & -50 & -8 & -40 & -21 \\
\hline $\begin{array}{ll}\text { Barometer } & \\
& \text { Initial } \\
& \text { Final }\end{array}$ & $\begin{array}{l}762 \\
760.8\end{array}$ & $\begin{array}{l}759.6 \\
755.2\end{array}$ & $\begin{array}{l}759.1 \\
752.9\end{array}$ & $\begin{array}{l}752.7 \\
758\end{array}$ \\
\hline $\begin{array}{r}\text { Temperature } \\
\text { Initial } \\
\text { Final }\end{array}$ & $\begin{array}{l}18 \\
20\end{array}$ & $\begin{array}{l}22 \\
22\end{array}$ & $\begin{array}{l}21 \\
23\end{array}$ & $\begin{array}{l}30 \\
31\end{array}$ \\
\hline $\begin{array}{ll}\text { Analyses } & \\
& \text { Initial } \mathrm{O}_{2} \\
& \text { Final } \mathrm{O}_{2} \\
\end{array}$ & $\begin{array}{l}20.930 \\
18.127\end{array}$ & $\begin{array}{l}41.800 \\
38.070\end{array}$ & $\begin{array}{l}61.329 \\
59.000\end{array}$ & $\begin{array}{l}75.273 \\
74.564\end{array}$ \\
\hline $\begin{array}{ll}\begin{array}{l}\text { C.c. } \mathrm{O}_{2} \\
760 \mathrm{~mm} .\end{array} & \text { at } \mathrm{O} \text { degree, } \\
& \text { Initial } \\
& \text { Final }\end{array}$ & $\begin{array}{l}693 \\
556\end{array}$ & $\begin{array}{l}1355 \\
1090\end{array}$ & $\begin{array}{l}1985 \\
1766\end{array}$ & $\begin{array}{l}2234 \\
2154\end{array}$ \\
\hline $\mathrm{O}_{2}$ loss & 137 & 265 & 219 & 80 \\
\hline $\begin{array}{l}\text { Dry weight of bacilli in } \\
\text { mgs }\end{array}$ & 80 & 85.95 & 80 & 30 \\
\hline Average & 80 & 90 & 80 & 30 \\
\hline$\frac{\text { Consumed } \mathrm{O}_{2}}{\text { Dry weight of bacilli }}$ & 1.8 & 1.5 & 2.9 & 3.2 \\
\hline
\end{tabular}

Chart 6

The growth and consumed oxygen curve of human tubercle bacilli(Kamiike III.) grown on glycerol broth in increased oxygen tension.

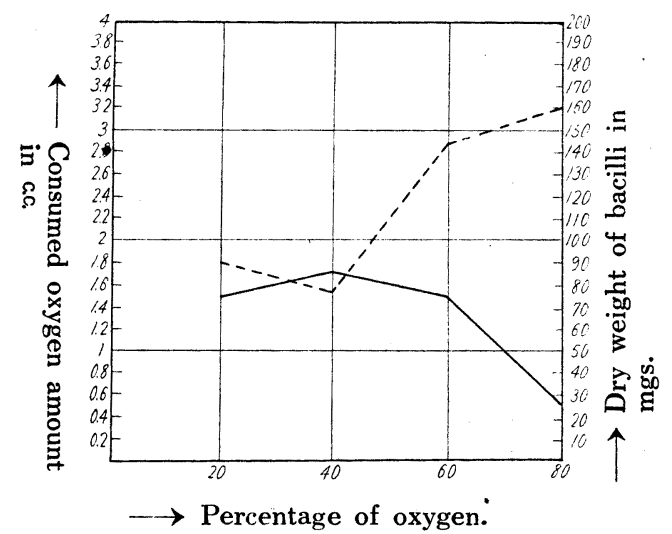

Growth curve.

Consumed oxygen curve. 
初 20.93 郎チ 693 c.c. アリタル酸素ハ最後 $=18.12 \%$ 郎チ 556 c.c. トナリ消費量ハ 137 c.c.

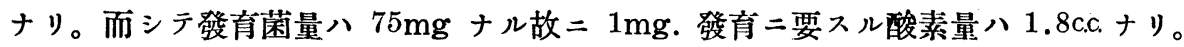
Experiment II ハ3580c.c. ノ容量ノJar チ用七 $40 \%$ /酸素分涯ノ下二試驗管 2 本き培 養セル成績ニシテ 3 週後 manometer ハー8 $\mathrm{mm}$ キ示シ最初 $41.8 \%$ 郎チ 1355 c.c. アリ タル酸素八最後 $=38.07 \%$ 郎チ 1090 c.c. トナリ消費量ハ 265 c.c. ニシテ發有菌量 ハ合計 $170 \mathrm{mg}$ ナル故 $=1 \mathrm{mg}$ 發育二要スル酸素量ハ1.5c.c.ナリ。Experiment III ハ3580c.c. ノ容量, Jar キ用七 $60 \%$ 酸素分厭ノ下二試驗管キ 1 本培養七ル成績ニシテ 3 週後 manometer ハー40mm キ示シ最初 $61.329 \%$ 節チ 1985 c.c. アリタル酸素ハ最後ニハ 59 \%師チ 1766 c.c. トナリ消費量ハ 219 c.c.ニシテ發有菌量ハ $75 \mathrm{mg}$.ナル故二 $1 \mathrm{mg}$. 發有二要 スル酸素量ハ2.9c.c.ナリ。Experiment IV ハ3480c.c.ノ容量ノJar チ用ヒ $80 \%$ ノ酸 素分壓ノ下二試驗管 1 本き培養セル成績ニシテ 3 週間目二 manometer ハ $-21 \mathrm{~mm}$ キ示シ最初 $75.273 \%$ 郎チ 2234 c.c.アリタルモノガ最後二 $74.564 \%$ 郎チ 2154 c.c. トナリ 消費ハ $80 \mathrm{ccc}$.ナリ。而シテ發有菌量ハ $25 \mathrm{mg}$.ナル故 $=1 \mathrm{mg}$.發有二要スル酸素量ハ $3.2 \mathrm{ccc}$. ナリ。以上ノ關係き curve ニテ表ハス時ハ Chart 6 ，如シ。郎チ菌量ハ $40 \%$ \% 最高 $85 \mathrm{mg}$.二達シ $60 \%$ ニテ $75 \mathrm{mg}$.二下降シ $80 \%$ テ $25 \mathrm{mg}$.二低下ス。酸素消費量， curve 八菌量ノ發有キ示ス curve ト正反對ノ動キキ示シ $40 \%$ ニテ低下シテ 1.5 c.c. ト

Table XV.

Analyses and oxygen requirement of human tubercle bacilli (Matsumoto) grown on glycerol broth in increased oxygen tension.

\begin{tabular}{|c|c|c|c|c|}
\hline No. of experiment & I & II & III & IV \\
\hline Planned percent. of oxygen & 20 & 40 & 60 & 80 \\
\hline Experimental material & Matsumoto & Matsumoto & Matsumoto & Matsumoto \\
\hline No. of days & 21 & 21 & 21 & 21 \\
\hline No. of tubes & 2 & 5 & 2 & 1 \\
\hline Net volume of Jar & 3560 & 3500 & $35 \overline{60}$ & 2080 \\
\hline Manometer & -44 & -43 & -60 & -60 \\
\hline $\begin{array}{ll}\text { Barometer } & \\
& \text { Initial } \\
& \text { Final } \\
\end{array}$ & $\begin{array}{l}760 \\
762.3 \\
\end{array}$ & $\begin{array}{l}738.2 \\
753 \\
\end{array}$ & $\begin{array}{l}758.1 \\
759 \\
\end{array}$ & $\begin{array}{l}746.9 \\
764 \\
\end{array}$ \\
\hline $\begin{array}{r}\text { Temperature } \\
\text { Initial } \\
\text { Final } \\
\end{array}$ & $\begin{array}{l}20 \\
20 \\
\end{array}$ & $\begin{array}{l}16 \\
21 \\
\end{array}$ & $\begin{array}{l}17 \\
20 \\
\end{array}$ & $\begin{array}{l}30 \\
\mathbf{2 3}\end{array}$ \\
\hline $\begin{array}{ll}\text { Analyses } & \\
& \text { Initial } \mathrm{O}_{2} \\
& \text { Final } \mathrm{O}_{2} \\
\end{array}$ & $\begin{array}{l}20.930 \\
15.536 \\
\end{array}$ & $\begin{array}{l}42.747 \\
28.402 \\
\end{array}$ & $\begin{array}{l}62.500 \\
60.567 \\
\end{array}$ & $\begin{array}{l}83.795 \\
81.400 \\
\end{array}$ \\
\hline 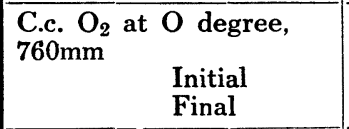 & $\begin{array}{l}678 \\
473\end{array}$ & $\begin{array}{r}1349 \\
839 \\
\end{array}$ & $\begin{array}{l}2049 \\
1802\end{array}$ & $\begin{array}{l}1477 \\
1403 \\
\end{array}$ \\
\hline $\mathrm{O}_{2}$ loss & $\overline{205}$ & 510 & 247 & 74 \\
\hline
\end{tabular}




\begin{tabular}{|l|c|c|c|c|}
\hline $\begin{array}{l}\text { Dry weight of bacilli in } \\
\text { mgs }\end{array}$ & 84.70 & $\begin{array}{l}105.85 .111 . \\
95.84\end{array}$ & 57.53 & 35 \\
\hline Average & 77 & 96 & 55 & 35 \\
\hline \begin{tabular}{c} 
Consumed $\mathrm{O}_{2}$ \\
\hline Dry weight of bacilli
\end{tabular} & 1.4 & 1.1 & 2.4 & 2.5 \\
\hline
\end{tabular}

Chart 7.

The growth and consumed oxygen curve of human tubercle bacilli (Matsumoto) grown on glycerol broth in increased oxygen tension.

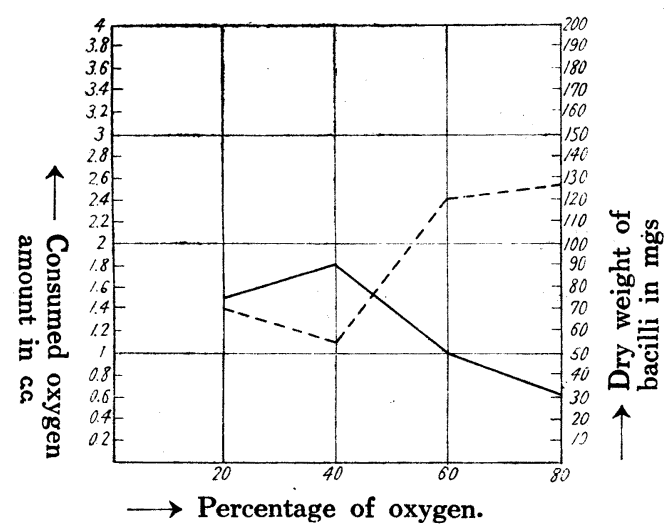

Growth curve.

Consumed oxygen curve.

ナリ $60 \%$ テテ昇 2.9 c.c.トナリ $80 \%$ テテ最高 3.2 c.c. トナル。

Table XV ハ人型結核菌松本き $40 \%$ 乃至 $80 \%$ ノ酸素厚ノ下二培養シタル成績ニシ テ Experiment I ハ3560c.c. ノ容量ノ Jar キ用七 $20 \%$ ノ酸素分壓ノ下二試驗管 2 本 キ培養セル成績ナリ。 3 週間後 manometer ハ $-44 \mathrm{~mm}$ チ示シ最初 $20.93 \%$ 郎チ 678 c.c.アリタルモノガ最後ニハ $15.536 \%$ 郎チ 473 c.c. トナリ消費量ハ 205 c.c. ニ シテ發育菌 量ハ合計 $144 \mathrm{mg}$. ナル故 $=1 \mathrm{mg}$. 發育二要スル酸素量ハ1.4c.c.ナリ。Experiment II ハ3500c.c. /容量ノ Jar キ用七 $40 \%$ /酸素分厴ノ下二試驗管 5 本 キ培養セル成績二 シテ 3 週後 manometer ハ $-43 \mathrm{~mm}$ キ示シ最初酸素 $42.747 \%$ 郎チ 1349 c.c.アリタル モノガ最後二 $28.402 \%$ 郎チ 839 c.c. トナリ消費量ハ 510 c.c. ニ シテ發育菌量ハ合計 455 mg. ナル故 $=1 \mathrm{mg}$. 發有二要スル酸素量ハ1.1c.c.ナリ。Experiment III ハ3560c.c. ， 容量ノJar キ用ヒ $60 \%$ 酸素分壓ノ下二試驗管 2 本キ培養セル成績ニシテ 3 週後 manometer ハ $-60 \mathrm{~mm}$ キ示 シ最初酸素 $62.5 \%$ 郎チ 2049 c.c. アリタルモノガ最後二 $60.567 \%$ 郎チ 1802 c.c.トナリ消費量ハ 247 c.c. ニシテ發育菌量ハ合計 $100 \mathrm{mg}$. ナル故二 $1 \mathrm{mg}$. 發育二要スル酸素量ハ2,4c.c.ナリ。

Experiment IV ハ2080c.c. ノ容量ノJar キ用七 $80 \%$ 酸素分厭ノ下二試驗管 1 本 キ培養セル成績ニシテ 3 週後 manometer ハ $-60 \mathrm{~mm}$ チ示シ最初酸素 $83.795 \%$ 郎チ 
.1477 c.c. アリタルモノガ最後二 $81.4 \%$ 郎チ 1403 c.c. トナリ消費量ハ 74 c.c. ニシテ發有菌 量ハ $30 \mathrm{mg}$.ナル故 $=1 \mathrm{mg}$.發育二要スル酸素量ハ 2 5c.c.ナリ。以上ノ關係子 curve 二 テ表ハス時ハ Chart 7 ノ如シ。郎チ菌量ハ $40 \%$ ニテ最高 $90 \mathrm{mg}$. 二達シ $60 \%$ ニテ 降シテ 50mg.トナリ $80 \%$ ニテ $30 \mathrm{mg}$.二低下ス。之二反シテ酸素消費量ハ $40 \%$ ニテ $1.1 \mathrm{ccc}$ 二低下 $=60 \%=$ テ $2.4 \mathrm{ccc}$ 二 二上昇シ $80 \%$ ニテ最高 $2.5 \mathrm{ccc}$ トナル。

Table.XVI 八牛型結核菌 No. 3 チ $40 \%$ 乃至 $80 \%$ /酸素分厭ノ下二培養シタル成 績ナリ。Experiment I ハ3580c.c. ノ容量ノJar キ用ヒ $20 \%$ ノ酸素分是ノ下二試驗管 1 本フ培養セル成績ニシテ 3 週後 manometer ハ $-30 \mathrm{~mm}$ キ示ス。最初酸素 $20.93 \%$ 即チ 653 c.c. アリタルモノガ最後 $=12.944 \%$ 郎チ 380 c.c. トナリ消費量ハ 273 c.c. ニシテ 發育菌量ハ $136 \mathrm{mg}$.ナル故二 $1 \mathrm{mg}$. 發有二要スル酸素量ハ1.9c.c.ナリ。Experiment II 八 3580 c.c. ノ容量, Jar キ用七 $40 \%$ /酸素分厘ノ下二試驗管 1 本 尹培養セル成績二 シテ 3 週後 manometer ハ-35mm タ示シ最初酸素 $40.816 \%$ 郎チ 1276 c.c.アリタル モノガ最後二 $32.655 \%$ 郎チ 985 c.c. トナリ消費量ハ 291 c.c.ナリ。而シテ發有菌量ハ 152

Table XVI.

Analyses and oxygen requirement of bovine tubercle bacilli (No. 3) grown on glycerol broth in increased oxygen tension.

\begin{tabular}{|c|c|c|c|c|}
\hline No. of experiment & I & II & III & IV \\
\hline Planned percent. of oxygen & 20 & 40 & 60 & 80 \\
\hline Experimental material & Bovine(No. 3) & Bovine(No. 3) & Bovine(No. 3) & Bovine (No. 3) \\
\hline No. of days & 21 & 21 & 21 & 21 \\
\hline No. of tubes & 1 & 1 & 2 & 1 \\
\hline Net volume of Jar & 3580 & 3580 & 3560 & 3385 \\
\hline Manometer & -30 & -35 & -50 & -18 \\
\hline $\begin{array}{cc}\text { Barometer } & \\
& \text { Initial } \\
& \text { Final } \\
\end{array}$ & $\begin{array}{l}759.1 \\
754.6 \\
\end{array}$ & $\begin{array}{l}761 \\
759 \\
\end{array}$ & $\begin{array}{l}749.8 \\
756.8 \\
\end{array}$ & $\begin{array}{l}759.1 \\
753.8 \\
\end{array}$ \\
\hline $\begin{array}{l}\text { Temperature } \\
\text { Initial } \\
\text { Final }\end{array}$ & $\begin{array}{c}28.5 \\
30\end{array}$ & $\begin{array}{l}28 \\
25 \\
\end{array}$ & $\begin{array}{r}23 \\
24 \\
\end{array}$ & $\begin{array}{l}28.5 \\
31 \\
\end{array}$ \\
\hline $\begin{array}{ll}\text { Analyses } & \text { Initial } \mathrm{O}_{2} \\
& \text { Final } \mathrm{O}_{2}\end{array}$ & $\begin{array}{l}20.930 \\
12.944 \\
\end{array}$ & $\begin{array}{l}40.816 \\
32.655 \\
\end{array}$ & $\begin{array}{l}65.971 \\
60.150 \\
\end{array}$ & $\begin{array}{l}79.789 \\
77.525 \\
\end{array}$ \\
\hline $\begin{array}{ll}\begin{array}{l}\text { C.c. } \mathrm{O}_{2} \\
\text { 760mm }\end{array} & \mathrm{O} \text { dagree, } \\
& \text { Initial } \\
& \text { Final }\end{array}$ & $\begin{array}{l}653 \\
380\end{array}$ & $\begin{array}{r}1276 \\
985 \\
\end{array}$ & $\begin{array}{l}2007 \\
1772\end{array}$ & $\begin{array}{l}2366 \\
2183\end{array}$ \\
\hline $\mathrm{O}_{2}$ loss & 273 & 291 & 255 & 183 \\
\hline $\begin{array}{l}\text { Dry weight of bacilli in } \\
\text { mgs }\end{array}$ & 141 & 157 & 94. 99 & 80 \\
\hline Average & 141 & 157 & 96 & 80 \\
\hline $\begin{array}{c}\text { Consumed } \mathrm{O}_{2} \\
\text { Dry weight of bacilli }\end{array}$ & 1.9 & 1.2 & 1.3 & 2.4 \\
\hline
\end{tabular}




\section{Chart 8.}

The growth and consumed oxygen curve of bovine tubercle bacilli (No. 3) grown on glycerol broth in increased oxygen tension.

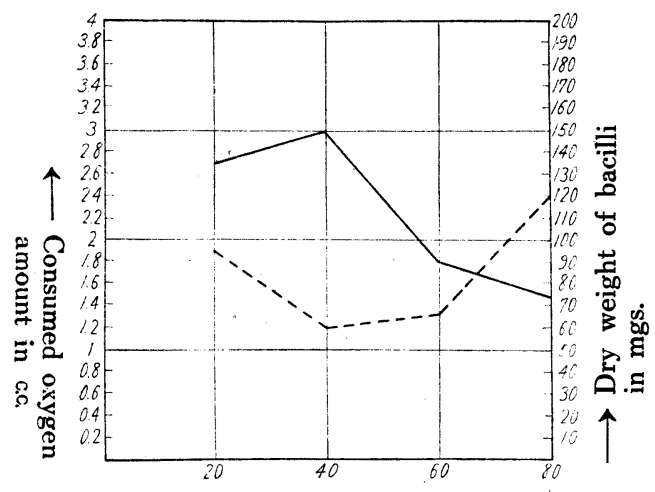

$\longrightarrow$ Percentage of oxygen.

Growth curve.

Consumed oxygen curve.

mg.ナル故 $=1 \mathrm{mg}$. 發有二要スル酸素量ハ $1.2 c . c$ ナリ。Experiment III ハ $3560 \mathrm{ccc}$ : ，

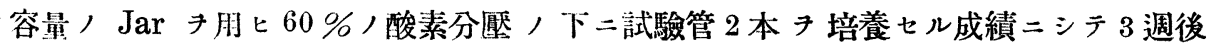
manometer ハ $-50 \mathrm{mg}$ タ示シ最初酸素 $65.971 \%$ 郎チ 2007 c.c.アリタルモノ最後二 $60.150 \%$ 郎チ 1772 c.c. トナリ消費量ハ 255 c.c. ニシテ發有菌量ハ $182 \mathrm{mg}$.ナル故 $=1 \mathrm{mg}$. 弡有二要スル酸素量ハ1.3c.c.ナリ。Experiment IV ハ 3385 c.c. ，容量，Jar キ用七 試驗管 1 本き $80 \%$ / 酸素分壓ノ下二培養セル成績ニシテ 3 週後 manometer $-18 \mathrm{~mm}$. キ示シ最初 $79.789 \%$ 郎チ 2366 c.c. アリタル酸素ハ最後二 $77.525 \%$ 郎チ 2183 c.c. トナリ 消費量ハ $183 \mathrm{ccc}$. ニシテ發有菌量ハ $75 \mathrm{mg}$. ナル故 $=1 \mathrm{mg}$. 發有二要スル酸素量ハ $2.4 \mathrm{ccc}$. ナリ。以上ノ關係キ curve ニテ表ハス時ハ Chart 8 ノ如シ。

荣量ハ $40 \%$ ニテ最高 $152 \mathrm{mg}$.二達シ $60 \%$ ニテ下降シテ $91 \mathrm{mg}$.トナリ $80 \%$ ニテ 59 mg.二低下ス。

酸素消費量ハ $40 \%$ ニテ $1.2 \mathrm{ccc}$ 二低下 $60 \%$ 二テ $1.3 \mathrm{ccc}$ 二上昇 $80 \%$ 二テ最高 $2.4 \mathrm{ccc}$. トナル。

Table XVII 八牛型結核菌 No. 6 丹 $20 \%$ 乃至 $80 \%$ ，酸素分涯，下二培養七ル成 績ニシテ Experiment I ハ3480c.c。，容量，Jar キ用七 $20 \%$ ）酸素分壓ノ下二試驗 管 1 本丹培養セル成績ニシテ 3 週後 manometer ハ $-1.5 \mathrm{~mm}$. キ示シ最初酸素 20.93 \%郎テ 624c.c. アリタルモノガ最後二 $18.521 \%$ 郎チ 562 c.c. トナリ消費量ハ 62 c.c. ニシテ 發有菌量ハ $50 \mathrm{mg}$ ナル故二 $1 \mathrm{mg}$.發有二要スル酸素量ハ $1.2 \mathrm{ccc}$. リ。Experiment II 八 3480 c.c. ，Jar 用七 $40 \%$ /酸素分壓ノ下二試驗管 1 本 培養セル成績ニシテ 3 
Table XVII.

Analyses and oxygen requirement of bovine tubercle bacilli (No. 6) grown on glycerol broth in increased oxygen tension.

\begin{tabular}{|c|c|c|c|c|}
\hline No. of experiment & I & II & III & IV \\
\hline Planned percent. of oxygen & 20 & 40 & 60 & 80 \\
\hline Experimental material & Bovine(No.6) & Bovine (No. 6) & Bovine (No.6) & Bovine(No. 6) \\
\hline No. of days & 21 & 21 & 21 & 21 \\
\hline No. of tubes & 1 & 1 & 1 & 1 \\
\hline Net volume of Jar & 3480 & 3480 & 3580 & 3580 \\
\hline Manometer & -15 & -33 & -24 & -37 \\
\hline $\begin{array}{ll}\text { Barometer } & \\
& \text { Initial } \\
& \text { Final } \\
\end{array}$ & $\begin{array}{l}759.2 \\
752.4\end{array}$ & $\begin{array}{r}752.6 \\
766\end{array}$ & $\begin{array}{l}759 \\
764.3\end{array}$ & $\begin{array}{l}747.4 \\
769.7\end{array}$ \\
\hline $\begin{array}{r}\text { Temperature } \\
\text { Initial } \\
\text { Final }\end{array}$ & $\begin{array}{l}32 \\
23\end{array}$ & $\begin{array}{l}25 \\
18\end{array}$ & $\begin{array}{l}25 \\
20 \\
\end{array}$ & $\begin{array}{l}22 \\
19 \\
\end{array}$ \\
\hline $\begin{array}{ll}\text { Analyses } & \\
& \text { Initial } \mathrm{O}_{2} \\
& \text { Final } \mathrm{O}_{2}\end{array}$ & $\begin{array}{l}20.930 \\
18.521\end{array}$ & $\begin{array}{l}42.448 \\
40.731\end{array}$ & $\begin{array}{l}62.112 \\
59.919\end{array}$ & $\begin{array}{l}81.703 \\
80.740 \\
\end{array}$ \\
\hline $\begin{array}{ll}\text { C.c. } \mathrm{O}_{2} & \text { at } \mathrm{O} \text { degree, } \\
760 \mathrm{~mm} & \text { Initial } \\
& \text { Final }\end{array}$ & $\begin{array}{l}624 \\
562\end{array}$ & $\begin{array}{l}1311 \\
1261\end{array}$ & $\begin{array}{l}1969 \\
1910\end{array}$ & $\begin{array}{l}2605 \\
2552 \\
\end{array}$ \\
\hline $\mathrm{O}_{2}$ loss & 62 & 50 & 59 & 53 \\
\hline $\begin{array}{l}\text { Dry weight of bacilli in } \\
\text { mgs }\end{array}$ & 55 & 63 & 45 & 30 \\
\hline$\frac{\text { Consumed } \mathrm{O}_{2}}{\text { Dry weight of bacilli }}$ & 1.2 & 0.8 & 1.4 & 2 \\
\hline
\end{tabular}

Chart 9.

The growth and consumed oxygen curve of bovine tubercle bacilli (No. 6) grown on glycerol broth in increased oxygen tension.

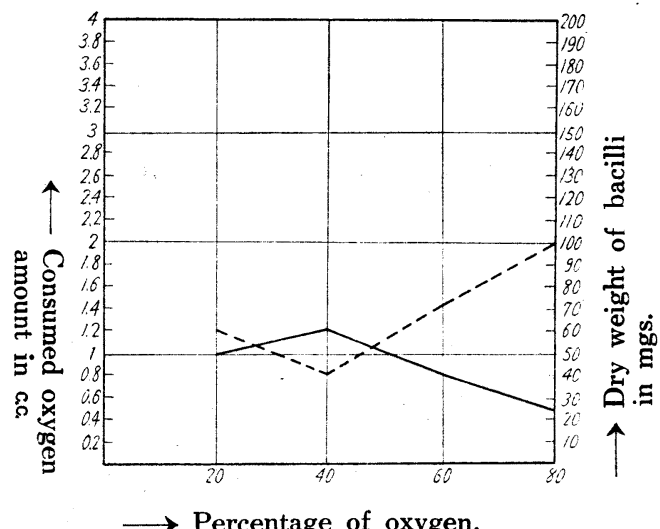

Growth curve.

Consumed oxygen curve. 
週後 manometer ハー $33 \mathrm{~mm}$. ヨ示シ最初 $42.448 \%$ 郎チ 1311 c.c. アリタル酸素八最後 $=40.731 \%$ 郎チ 1261 c.c. トナリ消費量ハ 50 c.c. ナリ。而シテ發有菌量ハ $58 \mathrm{mg}$.ナル故二 1 mg. 發有二要スル酸素量ハ0.8c.c.ナリ。Experiment III ハ3580c.c，容量ノJar キ用 ヒ $60 \%$ /酸素分壓ノ下二試驗管き 1 本培飬七ル成績ニシテ 3 週後 manometer ハ$24 \mathrm{~mm}$. 示シ最初 $62.112 \%$ 郎チ $1969 \mathrm{ccc}$ アリタル酸素八最後 $=59.919 \%$ 郎チ $1910 \mathrm{ccc}$. トナリ消費量ハ $59 \mathrm{ccc}$. ニシテ發育菌量ハ $40 \mathrm{mg}$.ナル故 $=1 \mathrm{mg}$.發有二要スル酸素量八

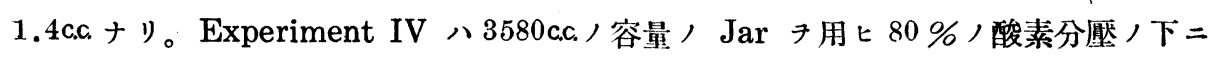
試驗管 1 本 培養七ル成績ニシテ 3 週後二ハ manometer ハ $-37 \mathrm{~mm}$ キ示シ最初 $81.703 \%$ 郎チ 2605 c.a アリタル酸素ハ最後 $=80.740 \%$ 郎チ 2552 c.c.トナリ消費量ハ 53 c.c. ニシテ發有菌量ハ $25 \mathrm{mg}$. ナル故 $=1 \mathrm{mg}$. 發育二要スル酸素量ハ $2 \mathrm{cc}$. ナリ。以上， 關係子 curve ニテ表ハス時ハ Chart 9 ，阴シ。

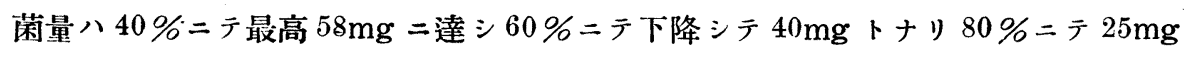
二低下ス。

Table XVIII.

Analyses and oxygen requiement of bovine tubercle bacilli (No. 2) grown on glycerol broth in increased oxygen tension.

\begin{tabular}{|c|c|c|c|c|}
\hline No. of experiment & $\mathbf{I}$ & II & III & IV \\
\hline Planned percent. of oxygen & 20 & 40 & 60 & 80 \\
\hline Experimental material & Bovine(No. 12) & $\operatorname{Bovine}($ No. 12) & Bovine $($ No.12) & Bovine(No.12) \\
\hline No. of days & 21 & 21 & 21 & 21 \\
\hline No. of tubes & 1 & 1 & 2 & 1 \\
\hline Net volume of Jar & 1610 & 2010 & 1990 & 1610 \\
\hline Manometer & -65 & -39 & -1 & -33 \\
\hline $\begin{array}{ll}\text { Barometer } & \\
& \begin{array}{l}\text { Initial } \\
\text { Final }\end{array} \\
\end{array}$ & $\begin{array}{l}759.4 \\
759.9\end{array}$ & $\begin{array}{l}758.3 \\
762.6\end{array}$ & $\begin{array}{l}751.5 \\
756.6\end{array}$ & $\begin{array}{l}757.4 \\
758.1\end{array}$ \\
\hline $\begin{array}{c}\text { Temperature } \\
\text { Initial } \\
\text { Final }\end{array}$ & $\begin{array}{l}24 \\
21\end{array}$ & $\begin{array}{l}25 \\
32 \\
\end{array}$ & $\begin{array}{l}27.5 \\
26\end{array}$ & $\begin{array}{l}27.5 \\
29\end{array}$ \\
\hline $\begin{array}{cc}\text { Analyses } & \\
& \text { Initial } \mathrm{O}_{2} \\
& \text { Final } \mathrm{O}_{2} \\
\end{array}$ & $\begin{array}{l}20.930 \\
11.400\end{array}$ & $\begin{array}{l}46.231 \\
40.310\end{array}$ & $\begin{array}{l}62.311 \\
53.409\end{array}$ & $\begin{array}{l}89.843 \\
88.428\end{array}$ \\
\hline $\begin{array}{ll}\begin{array}{l}\text { C.c. } \mathrm{O}_{2} \\
760 \mathrm{~mm}\end{array} & \text { at } \mathrm{O} \text { degree, } \\
& \text { Initial } \\
& \text { Final }\end{array}$ & $\begin{array}{l}306 \\
155\end{array}$ & $\begin{array}{l}717^{\circ} \\
594\end{array}$ & $\begin{array}{r}1076 \\
933\end{array}$ & $\begin{array}{l}1257 \\
1176\end{array}$ \\
\hline $\mathrm{O}_{2}$ loss & 151 & 123 & 143 & 81 \\
\hline $\begin{array}{l}\text { Dry weight of bacilli in } \\
\text { mgs }\end{array}$ & 131 & 140 & 70.80 & 55 \\
\hline Average & 131 & 140 & 75 & 55 \\
\hline $\begin{array}{c}\text { Consumed } \mathrm{O}_{2} \\
\text { Dry weight of cacilli }\end{array}$ & 1.2 & 0.9 & 1.0 & 1.6 \\
\hline
\end{tabular}


Chart 10.

The grown and consumed oxygen curve of bovine tubercle bacilli (No. 2) grown on glycerol broth in increased oxygen tension.

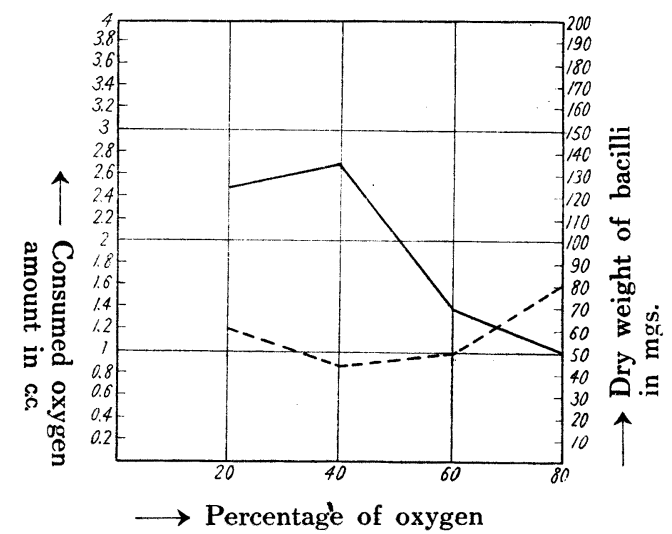

Growth curve. $\quad$-...... Consumed oxygen curve.

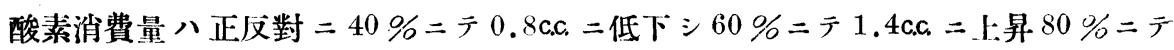
2c.c. 二達入。

Table XVIII 八牛型結核菌 No. 12 于 $20 \%$ 乃至 $80 \%$ ，酸素分壓 下二培養七ル䐝 驗ナリ。Experiment I ハ1610c.c.，容量，Jar チ用七 $20 \%$ ／酸素分是，下二試驗 管 1 本丹培養セル成績ニシテ 3 週後 manomenter ハ $-65 \mathrm{~mm}$ キ示シ最初酸素 20.93 \%郎チ 306 c.c. アリタルモノガ最後ニハ 11.4\%郎チ 155 c.c. トナリ消費量ハ 151c.c. ニ テ發有菌量ハ $126 \mathrm{mg}$.ナル故二 $1 \mathrm{mg}$.發有二要スル酸素量ハ $1.2 \mathrm{ccc}$.ナリ。Experiment

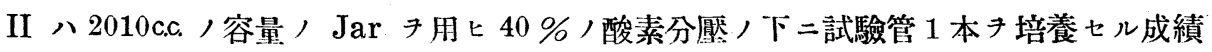
ニシテ 3 週後 manometer ハ $-39 \mathrm{~mm}$ チ示シ最初 $46.231 \%$ 郎チ 717 c.c. アリタル酸素 八最後 $=40.310 \%$ 師于 594 c.c. トナリ消費量ハ 123 c.c. ニシテ發有菌量ハ $135 \mathrm{mg}$.ナル故 $=1 \mathrm{mg}$. 發育二要スル酸素量ハ0.9c.c.ナリ。Experiment III ハ1990c.c. ，容量，Jar 尹用七 $60 \%$ /酸素分厭,下二試驗管 2 本丹培養セル成績ニシテ 3 週後 manometer ハー $1 \mathrm{~mm}$ キ示シ最初酸素 $62.311 \%$ 郎チ $1076 \mathrm{ccc}$ アリタルモノガ最後 $=53.409 \%$ 郎 チ 933c.c. トナリ消費量ハ 143c.c.ナリ。而シテ發有菌量八合計 $140 \mathrm{mg}$.ナル故 $=1 \mathrm{mg}$.發 育二要スル酸素量ハ1.0c.c。ナリExperiment IV ハ1610c.c.；容量ノJar キ用七 80 $\%$ /酸素分栥ノ下二試驗管 1 本子培養七ル成績ニシテ 3 週後 manometer ハ $-33 \mathrm{~mm}$ キ示シ最初酸素 $89.843 \%$ 郎チ 1257 c.c. アリタルモノガ最後= $88.428 \%$ 郎チ 1176 c.c. 卜 ナリ消費量ハ $81 \mathrm{ccc}$.ニシテ發有菌量ハ $50 \mathrm{mg}$.ナル故二 $1 \mathrm{mg}$. 發有二要スル酸素量ハ 1.6 c.c.ナリ。 
以上ノ關係 7 curve ニテ表ハス時ハ Chart 10 ノ如シ。菌量ハ $40 \%$ テ最高 135 $\mathrm{mg}$ 。二達シ $60 \%$ 二 $70 \mathrm{mg}$.二下降シ $80 \%$ ニテ最低 $50 \mathrm{mg}$.二低下゙ス。

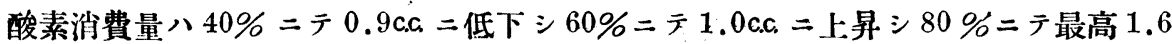
c.c. $=$ 達 ス。

Table XIX 八牛型結核菌 No. 14 丹 $20 \%$ 乃至 $80 \%$ 八酸素分是，下二培養シタル 實驗ニシテ Experiment I ハ1590c.c.，容量，Jar チ用ヒ $20 \%$ 酸素分厭ノ下二試 驗管 2 本み培養セル成績ニシテ 3 週後 manometer ハー52mm キ示シ最初酸素 20.93 \%郎チ 311 c.c. アリタルモノガ最後二 $1.361 \%$ 郎チ 21 c.c. トナリ消費量ハ 290 c.c. ニシテ 發有菌量八合計 $230 \mathrm{mg}$.ナル故二 $1 \mathrm{mg}$.發有二要スル酸素量ハ1.2c.c。ナリ。Experiment II ハ 3560 c.c. ，容量ノJar キ用七 $40 \%$ /酸素分厴二下二試驗管 2 本き培養シタル成 績ニシテ 3 週後 manometer ハ $-2 \mathrm{~mm}$. キ示シ最初酸素 $40.702 \%$ 郎チ $1315 \mathrm{ccc}$. アリタ ルモノガ最後 $=32.96 \%$ 郎チ 1054 c.c. トナリ消費量ハ 261 c.c. ニシテ發育菌量ハ合計 278 $\mathrm{mg}$.ナル故 $=1 \mathrm{mg}$.發育二要スル酸素量ハ $0.9 \mathrm{ccc}$ ナリ。Experiment III ハ 3560 ，容

Table XIX.

Analyses and oxygen requirement of bovine tubercle bacilli (No. 14) grown on glycerol broth in increased oxygen tension.

\begin{tabular}{|c|c|c|c|c|}
\hline No. of experiment & I & II & III & IV \\
\hline Planned percent. of oxygen & 20 & 40 & 60 & 80 \\
\hline Experimental material & Bovine $($ No.14) & Bovine $($ No.14) & Bovino(No.14) & Bovine(No.14) \\
\hline No. of days & 21 & 21 & 21 & 21 \\
\hline No. of tubes & 2 & 2 & 2 & 1 \\
\hline Net volume of Jar & 1590 & 3560 & 3560 & 2000 \\
\hline Manometer & -52 & -2 & -26 & -70 \\
\hline $\begin{array}{ll}\text { Barometer } & \\
& \text { Initial } \\
& \text { Final } \\
\end{array}$ & $\begin{array}{l}760.7 \\
759.4\end{array}$ & $\begin{array}{l}754 \\
756.2 \\
\end{array}$ & $\begin{array}{l}762.8 \\
767.7\end{array}$ & $\begin{array}{l}746.9 \\
764\end{array}$ \\
\hline $\begin{array}{c}\text { Temperature } \\
\text { Initial } \\
\text { Final }\end{array}$ & $\begin{array}{l}20 \\
24\end{array}$ & $\begin{array}{l}20 \\
22\end{array}$ & $\begin{array}{l}18 \\
22\end{array}$ & $\begin{array}{l}30 \\
23\end{array}$ \\
\hline $\begin{array}{ll}\text { Analyses } & \text { Initial } \mathrm{O}_{2} \\
& \text { Final } \mathrm{O}_{2}\end{array}$ & $\begin{array}{r}20.930 \\
1.361\end{array}$ & $\begin{array}{l}40.702 \\
32.960\end{array}$ & $\begin{array}{l}58.502 \\
55.324\end{array}$ & $\begin{array}{l}81.437 \\
76.847\end{array}$ \\
\hline $\begin{array}{ll}\begin{array}{l}\text { C.c. } \mathrm{O}_{2} \\
760 \mathrm{~mm}\end{array} & \text { at } \mathrm{O} \text { degree, } \\
& \text { Initial } \\
& \text { Final }\end{array}$ & $\begin{array}{r}311 \\
21\end{array}$ & $\begin{array}{l}1315 \\
1054\end{array}$ & $\begin{array}{r}1928 \\
1730\end{array}$ & $\begin{array}{l}1355 \\
1224 \\
\end{array}$ \\
\hline $\mathrm{O}_{2}$ loss & 290 & 261 & 198 & 131 \\
\hline $\begin{array}{l}\text { Dry weight of bacilli in } \\
\text { mgs }\end{array}$ & 123. 117 & 166. 122 & 71. 74 & 60 \\
\hline Average & 120 & 144 & 72 & 60 \\
\hline $\begin{array}{c}\text { Consumed } \mathrm{O}_{2} \\
\text { Dry weight of bacilli }\end{array}$ & 1.2 & 0.9 & 1.4 & . 2 \\
\hline
\end{tabular}


Chart 11.

The growth and consumed oxygen curve of bovine tubercle bacilli (No. 14) grown on glycerol broth in increased oxygen tension.

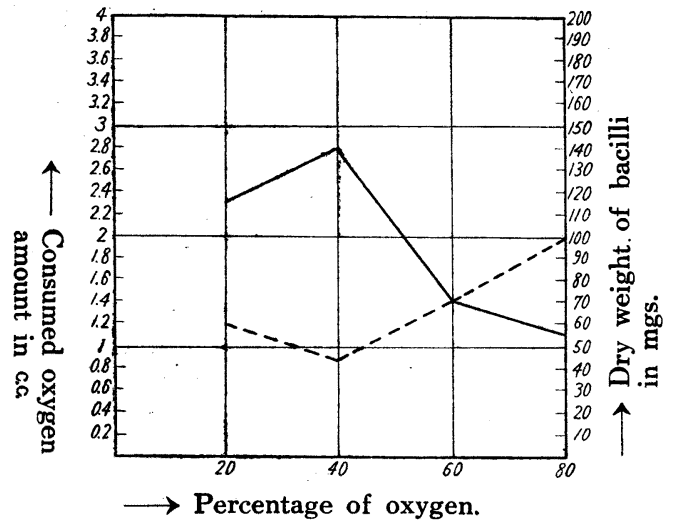

Growth curve.

Consumed oxygen curve.

量, Jar キ用ヒ $60 \%$ 酸素分涯ノ下二試驗管 2 本キ培養シタル成績ニシテ 3 週後 manometer ハ $-26 \mathrm{~mm}$. キ示シ最初酸素 $58.502 \%$ 郎チ 1928 c.c.アリタルモノガ最後二 $55.324 \%$ 郎チ $1730 \mathrm{ccc}$ トナリ消費量ハ 198c.c. シテ發有菌量 ハ合計 $135 \mathrm{mg}$ ナル故二 1mg.發育二要スル酸素量ハ1.4c.aナリ。Experiment IVハ2000c.c。容量，Jar キ 用七 $80 \%$ /酸素分壓ノ下二試驗管 1 本き培養七ル成績ニシテ 3 週後二 manometer ハー70 mm. キ示シ最初酸素 $81.437 \%$ 郎チ $1355 \mathrm{ccc}$ アリタルモノガ最後 $=76.847 \%$ 郎

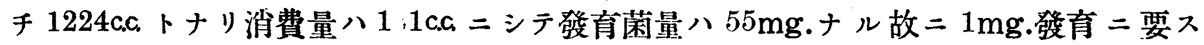
ル酸素量ハ 2c.c.ナリ。以上ノ關係子 curve ニテ表ハス時ハ Chart 11 /如シ。

菌量ハ $40 \%$ ニテ最高 $139 \mathrm{mg}$.二達シ $60 \%$ ニテ $67 \mathrm{mg}$.二下降シ $80 \%$ ニテ $55 \mathrm{mg}$.二低 下ス。

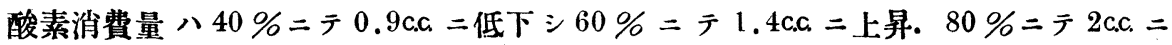
達ス。

Table XX ハ牛型結核菌北研チ $20 \%$ 乃至 $80 \%$ /酸素分厚，下二培養セル實驗ナ リ。Experiment I ハ3540c.c，容量，Jar キ用七 $20 \%$ /酸素分厘，下二試驗管 3 本ヲ培養七ル成績ニシテ 3 週後 manometer ハー52mm. チ示シ最初酸素量 $20.93 \%$ 郎チ 663c.c. アリタルモノガ最後二 $0.424 \%$ 郎チ 12 c.c. トナリ消費量八 651 c.c. ニシテ發 有菌量八合計 $384 \mathrm{mg}$.ナル故 $=1 \mathrm{mg}$.發有二要スル酸素量ハ1.6c.a ナリ。Experiment II ハ 2060 c.c. ノ容量ノJar キ用七 $40 \%$ 酸素分厘ノ下二試驗管 2 本キ培養セル成績 ニシテ 3 週後 manometer ハー63mm チ示シ最初酸素 $38.271 \%$ 郎チ $688 \mathrm{c} \cdot \mathrm{c} \cdot$ ソリル 
Table XX.

Analyses and oxygen requirement of bovine tubercle bacilli (Hokken) grown on glycerol broth in increased oxygen tension.

\begin{tabular}{|c|c|c|c|c|}
\hline No. of experiment & $\mathbf{I}$ & II & III & IV \\
\hline Planned percent. of oxygen & 20 & 40 & 60 & 80 \\
\hline Experimental material & $\begin{array}{c}\text { Bovine } \\
\text { (Hokken) }\end{array}$ & $\begin{array}{c}\text { Bovine } \\
\text { (Hokken) }\end{array}$ & $\begin{array}{c}\text { Bovine } \\
\text { (Hokken) }\end{array}$ & $\begin{array}{c}\text { Bovine } \\
\text { (Hokken) }\end{array}$ \\
\hline No. of days & 21 & 21 & 21 & 21 \\
\hline No. of tubes & 3 & 2 & 5 & 2 \\
\hline Net volume of Jar & 3540 & 2060 & 3500 & 3420 \\
\hline Manometer & -52 & -63 & -77 & -50 \\
\hline $\begin{aligned} \text { Barometer } & \\
& \text { Initial } \\
& \text { Final }\end{aligned}$ & $\begin{array}{l}755.6 \\
756.5\end{array}$ & $\begin{array}{l}743.5 \\
758.9\end{array}$ & $\begin{array}{l}755.5 \\
764.6\end{array}$ & $\begin{array}{l}746.9 \\
764\end{array}$ \\
\hline $\begin{array}{c}\text { Temperature } \\
\text { Initial } \\
\text { Final }\end{array}$ & $\begin{array}{l}22 \\
19\end{array}$ & $\begin{array}{l}21 \\
26\end{array}$ & $\begin{array}{l}16 \\
21\end{array}$ & $\begin{array}{l}30 \\
23\end{array}$ \\
\hline $\begin{array}{ll}\text { Analyses } & \text { Initial } \mathrm{O}_{2} \\
& \text { Final } \mathrm{O}_{2} \\
\end{array}$ & $\begin{array}{r}20.930 \\
0.424 \\
\end{array}$ & $\begin{array}{l}38.271 \\
17.628\end{array}$ & $\begin{array}{l}61.180 \\
33.505\end{array}$ & $\begin{array}{l}84.649 \\
72.289\end{array}$ \\
\hline $\begin{array}{ll}\begin{array}{l}\text { C.c. } \mathrm{O}_{2} \\
760 \mathrm{~mm}\end{array} & \mathrm{O} \text { degree, } \\
& \text { Initial } \\
& \text { Final }\end{array}$ & $\begin{array}{r}663 \\
12\end{array}$ & $\begin{array}{l}688 \\
329\end{array}$ & $\begin{array}{r}1974 \\
957\end{array}$ & $\begin{array}{l}2446 \\
2074\end{array}$ \\
\hline $\mathrm{O}_{2}$ loss & 651 & 359 & 1017 & 372 \\
\hline $\begin{array}{l}\text { Dry weight of bacilli in } \\
\text { mgs. }\end{array}$ & 144.130 .125 & 135. 137 & $\begin{array}{l}132.127 .130 \\
127.110\end{array}$ & 106. 92 \\
\hline Average & 133 & 136 & 125 & 99 \\
\hline$\frac{\text { Consumed } \mathrm{O}_{2}}{\text { Dry weight of bacilli }}$ & 1.6 & 1.3 & 1.7 & 2.0 \\
\hline
\end{tabular}

Chart 12.

The growth and consumed oxygen curve of bovine tubercle bacilli (Hokken) grown on glycerol broth in increased oxygen tension.

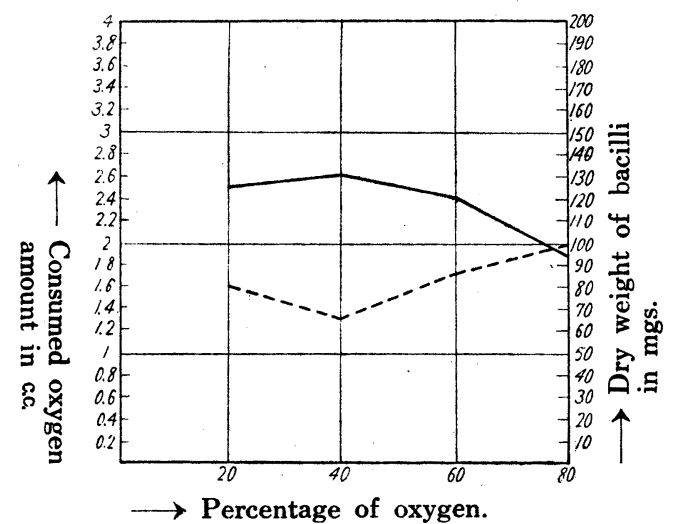

Growth curve. Consumed oxygen curve. 
モノガ最後 $=17.628 \%$ 郎チ 329 c.c. トナリ消費量ハ 359 c.c. ニ シテ發育菌量ハ合計 262 $\mathrm{mg}$.ナル故 $=1 \mathrm{mg}$.發有二要スル酸素量ハ1.3c.c.ナリ。Experiment III ハ 3500 c.c. ， 容量ノJar キ用七 $60 \%$ /酸素分㕓,下二試驗管 5 本 培養七ル成績ニシテ 3 週後 manometer ハ $-77 \mathrm{~mm}$ キ示シ最初酸素 $61.180 \%$ 郎チ1974c.. アリタルモノガ最後 $=33.50 ％$ 郎チ 957 c.c. トナリ消費量ハ 1017 c.c. ニシテ發育菌量八合計 $600 \mathrm{mg}$.ナル故 $=1 \mathrm{mg}$.發育二要スル酸素量ハ 1.7 c.c. ナリ。Experiment IV， $3420 \mathrm{c.cc}$ ，容量，Jar

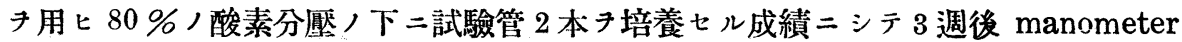
八 $-50 \mathrm{~mm}$. キ示シ最初酸素量 $84.649 \%$ 郎チ 2446 c.c. アリタルモノガ最後 $=72.289 \%$ 師チ 2074 c.c. トナリ消費量ハ 372 c.c. ニシテ發育菌量ハ合計 $188 \mathrm{mg}$.ナル故 $=1 \mathrm{mg}$.發育 二要スル酸素量ハ2.0c.c.ナリ。以上ノ關係き curve ニテ表ハス時ハ Chart 12 ，如シ。 菌量ハ $40 \%$ ニテ最高 $131 \mathrm{mg}$.二達シ $60 \%$ ニテ $20 \mathrm{mg}$.二低下シ $80 \%$ ニテ最低 $94 \mathrm{mg}$. 二達ス。

酸素消費量ハ $40 \%$ 二テ 1.3 二低下シ $60 \%$ ニテ $1.7 \mathrm{ccc}$ 二 二上昇 $80 \%$ 二テ最高 $2.0 \mathrm{ccc}$.

Table XXI.

Analyses and oxygen requirement of B.C.G. grown on glycerol broth in increased oxygen tension.

\begin{tabular}{|c|c|c|c|c|}
\hline No. of experiment & I & II & III & IV \\
\hline Planned percent. of oxygen & 20 & 40 & 60 & 80 \\
\hline Experimental material & B.C.G. & B.C.G.! & B.C.G. & B.C.G. \\
\hline No. of days & 21 & 21 & 21 & 21 \\
\hline No. of tubes & 3 & 3 & 1 & 1 \\
\hline Net volume of Jar & 3340 & 3540 & 1980 & 1980 \\
\hline Manometer & -48 & $-4 \overline{4}$ & -34 & -3 \\
\hline \begin{tabular}{|l} 
Barometer \\
\\
\\
Initial \\
Final \\
\end{tabular} & $\begin{array}{r}756.2 \\
755.6 \\
\end{array}$ & $\begin{array}{r}755.2 \\
760.2 \\
\end{array}$ & $\begin{array}{l}757.4 \\
758.1 \\
\end{array}$ & $\begin{array}{l}757.4 \\
758.1\end{array}$ \\
\hline $\begin{array}{c}\text { Temperature } \\
\text { Initial } \\
\text { Final }\end{array}$ & $\begin{array}{l}23 \\
22\end{array}$ & $\begin{array}{l}21 \\
23\end{array}$ & $\begin{array}{c}27.5 \\
29\end{array}$ & $\begin{array}{c}27.5 \\
29\end{array}$ \\
\hline $\begin{array}{ll}\text { Analyses } & \text { Initial } \mathrm{O}_{2} \\
& \text { Final } \mathrm{O}_{2} \\
\end{array}$ & $\begin{array}{r}20.930 \\
0.274\end{array}$ & $\begin{array}{l}43.686 \\
32.267\end{array}$ & $\begin{array}{l}63.596 \\
60.091 \\
\end{array}$ & $\begin{array}{l}87.058 \\
82.713\end{array}$ \\
\hline $\begin{array}{ll}\text { C.c. } \mathrm{O}_{2} \text { at } & \mathrm{O} \text { degree, } \\
760 \mathrm{~mm} & \text { Initial } \\
& \text { Final }\end{array}$ & $\begin{array}{r}623 \\
8\end{array}$ & $\begin{array}{r}1391 \\
936\end{array}$ & $\begin{array}{r}1095 \\
980\end{array}$ & $\begin{array}{l}1500 \\
1412\end{array}$ \\
\hline $\mathrm{O}_{2}$ loss & 615 & 455 & 115 & 88 \\
\hline $\begin{array}{l}\text { Dry weight of bacilli in } \\
\text { mgs. }\end{array}$ & 76.67 .78 & 55.55 .56 & 41 & 31 \\
\hline Average & 77 & 55 & 41 & 31 \\
\hline $\begin{array}{c}\text { Consumed } \mathrm{O}_{2} \\
\text { Dry weight of bacilli }\end{array}$ & 3 & 3 & 3.2 & 3.4 \\
\hline
\end{tabular}


Chart 13.

The growth and consumed oxygen curve of B.C.G. grown on glycerol broth in increased oxygen tension.

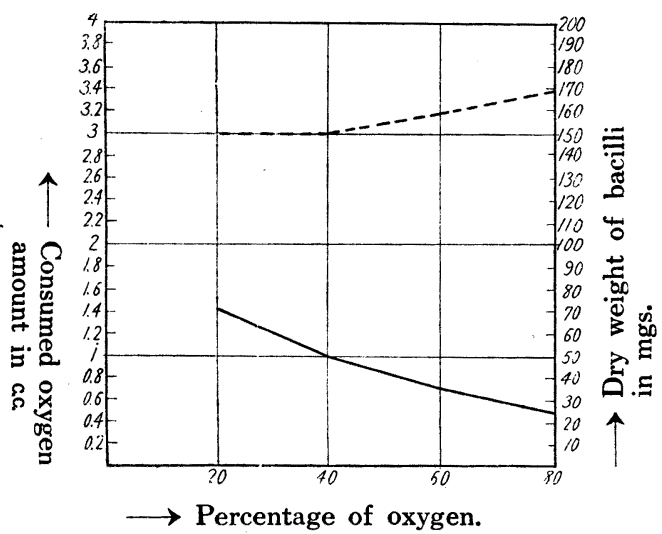

Growth curve.

Consumed oxygen curve.

二達入。

Table XXI ハ B.C.G 菌キ $20 \%$ 乃至 $80 \%$ /酸素分磨ノ下二培養七ル實驗ニシテ

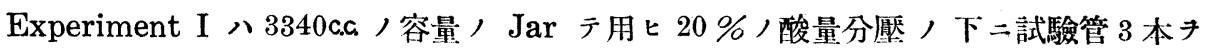
培養セル成績ニシテ 3 週後 manometer $-48 \mathrm{~mm}$ キ示 シ最初 $20.93 \%$ 郎チ $623 \mathrm{cccc}$ ○ リタル酸素 ハ最後 $=0.274 \%$ 郎チ 8 c.c. トナリ消費量ハ $615 \mathrm{ccc}$. ニシテ發有菌量 八合計 $206 \mathrm{mg}$.ナル故 $=1 \mathrm{mg}$.發育二要スル酸素量ハ3c.c.ナリ。Experiment II ハ 3540 c.c. ， 容量ノJar キ用七 $40 \%$ /酸素分厴，下二試驗管 3 本 $テ$ 培養七ル成績二シテ 3 週 後 manometer ハ $44 \mathrm{~mm}$. キ示シ最初 $43.686 \%$ 郎チ 1391 c.c. アリタル酸素八最後二 $32.267 \%$ 師チ 936 c.c. トナリ消費量ハ 455 c.c. ニシテ發育菌量 ハ合計 $151 \mathrm{mg}$.ナル故二 $1 \mathrm{mg}$. 發有二要スル酸素量ハ 3c.c.ナリ。Experiment III ハ1980c.c.，容量，Jar 尹用 ヒ $60 \%$ /酸素分厚ノ下二試驗管 1 本チ培養七ル成績ニシテ 3 週後二 manometer 八 -34mm. キ示 シ最初 $63.596 \%$ 郎チ 1095 c.c. アリタル酸素ハ最後二 $60.091 \%$ 郎チ 980 c.c. トナリ消費量ハ $115 \mathrm{ccc}$. ニシテ發有菌量ハ $36 \mathrm{mg}$ ナル故 $=1 \mathrm{mg}$ 發有二要スル酸素量 ハ 3.2 c.c.ナリ。Experiment IV ハ1980c.c. /容量, Jar キ用七 $80 \%$ /酸素分壓ノ下 二試驗管 1 本丹培養セル成績ニシテ 3 週後 manometer ハー3mm. キ示シ最初 87.058 \%郎チ 1500 c.c. アリタル酸素八最後二 $82.713 \%$ 郎チ 1412 c.c. トナリ消費量ハ 88 c.c. ニシ テ發有菌量ハ $26 \mathrm{mg}$.ナル故 $=1 \mathrm{mg}$.發有二要スル酸素量ハ $3.4 \mathrm{ccc}$. リ。

以上ノ關係尹 curve ニテ表ハス㭙ハ Chart 13 ノ如シ。

B.C.G. 八他ノ結核菌ト異ナリ菌量八酸素ノ濃度,增加卜共二減少シ結核菌ノ如ク。 
$40 \%$ テ上开スル事ナシ。郎チ $40 \%$ ニテ $50 \mathrm{mg}$.二低下 シ $60 \%$ ニテハ更 $=36 \mathrm{mg}$. = 又8 $80 \%$ ニテ最低 $25 \mathrm{mg}$. ニ下降ス。

Table XXII.

Analyses and oxygen requirement of avian tubercle bacilli grown on glycerol broth in increased oxygen tension.

\begin{tabular}{|c|c|c|c|c|}
\hline No. of experiment & I & II & III & IV \\
\hline Planned percent. of oxygen & 20 & 40 & 60 & 80 \\
\hline Experimental material & Avian type & Avian type & Avian type & Avian type \\
\hline No. of days & 21 & 21 & 21 & 21 \\
\hline No. of tubes & 1 & 1 & 1 & 1 \\
\hline Net volume of Jar & 1610 & 3580 & 3480 & 3580 \\
\hline Manometer & -47 & -1 & -1 & -60 \\
\hline $\begin{array}{ll}\text { Barometer } & \\
& \begin{array}{l}\text { Initial } \\
\text { Final }\end{array}\end{array}$ & $\begin{array}{l}745.8 \\
749.5\end{array}$ & $\begin{array}{l}762 \\
762.7\end{array}$ & $\begin{array}{l}762 \\
762.7\end{array}$ & $\begin{array}{l}757.7 \\
764\end{array}$ \\
\hline $\begin{array}{ll}\text { Temperatur } & \\
& \text { Initial } \\
& \text { Final }\end{array}$ & $\begin{array}{l}23 \\
25\end{array}$ & $\begin{array}{l}24 \\
29.5\end{array}$ & $\begin{array}{l}24 \\
29.5\end{array}$ & $\begin{array}{l}29 \\
23\end{array}$ \\
\hline $\begin{array}{ll}\text { Analyses } & \\
& \text { Initial } \mathrm{O}_{2} \\
& \text { Final } \mathrm{O}_{2}\end{array}$ & $\begin{array}{c}20.93 \\
0.0\end{array}$ & $\begin{array}{l}46.700 \\
38.797\end{array}$ & $\begin{array}{l}67.513 \\
63.027\end{array}$ & $\begin{array}{l}86.302 \\
83.357\end{array}$ \\
\hline $\begin{array}{ll}\begin{array}{l}\text { C.c. } \mathrm{O}_{2} \\
760 \mathrm{~mm}\end{array} & \text { at } \mathrm{O} \text { degree, } \\
& \text { Initial } \\
& \text { Final }\end{array}$ & $\begin{array}{r}295 \\
0\end{array}$ & $\begin{array}{l}1494 \\
1207\end{array}$ & $\begin{array}{l}2101 \\
1892\end{array}$ & $\begin{array}{l}2673 \\
2474\end{array}$ \\
\hline $\mathrm{O}_{2}$ loss & 295 & 287 & 209 & 199 \\
\hline $\begin{array}{l}\text { Dry weight of bacilli in } \\
\text { mgs }\end{array}$ & 176 & 180 & 185 & 177 \\
\hline$\frac{\text { Consumed } \mathrm{O}_{2}}{\text { Dry weight of bacilli }}$ & 1.7 & 1.6 & 1.1 & 1.1 \\
\hline
\end{tabular}

Chart 14.

The growth and consumed oxygen curve of avian tubercle bacilli grown on glycerol broth in increased oxygen tension.

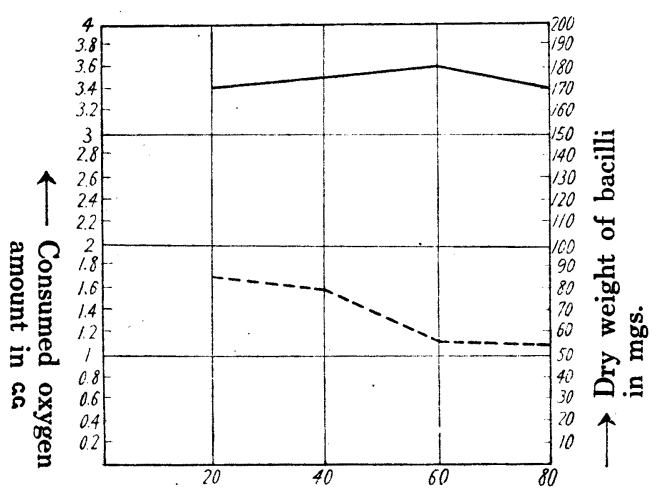

$\longrightarrow$ Percentage of oxygen.

Growth curve.

Consumed oxygen curve. 
酸素消費量モ他ノ結核菌卜. 異ナリ $40 \%$ 二 $20 \%$ 同樣 $3 \mathrm{ccc}$. 二テ $60 \%=$ $3.2 \mathrm{ccc} .=$ 上昇 $80 \%$ 二テ最高 3.4 c.c. 二達入。菌量, curve /動キ八酸素ノ濃度ノ增加スル二從 ツテ下降シ酸素消費量八酸素ノ濃度ノ進ム二從ツテ上昇ス。

Table XXII 八鳥型結核菌子 $20 \%$ 乃至 $80 \%$ ，酸素分壓，下二培養 シタル實驗二 シテ Experiment I ハ 1610 c.c. ，容量，Jar キ用七。20\%)酸素分壓，下二試驗管 1 本ヨ培養セル成績ニシテ 3 週後 manometer ハ $-47 \mathrm{~mm}$. キ示シ最初 $20.93 \%$ 郎チ 295 c.c.アリタル酸素ハ最後ニ0\%トナリ消費量ハ $295 \mathrm{ccc}$.ニシテ發育菌量ハ $171 \mathrm{mg}$.ナル故 =1mg. 發有二要スル酸素量ハ 1.7 c.c.ナリ。Experiment II ハ3580c.c. ，容量，Jär

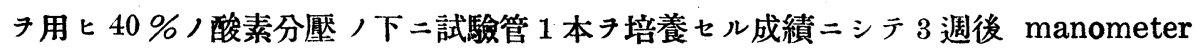
八 $-1 \mathrm{~mm}$. キ示シ最初 $46.7 \%$ 郎チ 1494 c.c. アリタル酸素八最後 $=38.797 \%$ 郎チ 1207 c.c.トナリ消費量ハ 287 c.c. ニシテ發有菌量ハ $175 \mathrm{mg}$ ナル故 $=1 \mathrm{mg}$ 發育二要スル酸素量 ハ1.6c.c.ナリ。Experiment III, ハ3480c.c. ，容量，Jar キ用七 $60 \%$ 酸素分厘， 下二試驗管 1 本キ培養シタル成績ニシテ 3 週後 manometer ハー1mm. キ示シ最初 $67.513 \%$ 師チ 2101 c.c。アリタル酸素ハ最後二 $63.027 \%$ 師チ 1892 c.c.トナリ消費量ハ

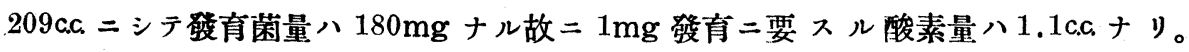
Experiment IV ハ $3580 \mathrm{ccc}$ ，Jar キ用七 $80 \%$ 酸素分厓 下二試驗管 1 本キ培養 七ル成績ニシテ 3 週後 manometer ハ $-60 \mathrm{~mm}$ ナ示シ最初 $86.302 \%$ 郎チ $2673 \mathrm{ccc}$ 厂 リタル酸素八最後 $=83.357 \%$ 郎チ 2474 c.c. トナリ消費量ハ $199 \mathrm{ccc}$. ニ シテ發育菌量八 $172 \mathrm{mg}$.ナル故 $=1 \mathrm{mg}$.發育二要スル酸素量ハ1.1c.c.ナリ。以.上／關係キ curve 二テ 表ハス時八Chart 14 ノ如ジ。

菌量八酸素ノ濃度, 增加卜共二增シ $40 \%$ ニテハ $175 \mathrm{mg} .60 \%$ ニテ最高 $180 \mathrm{mg} .=$ 達シ $80 \%$ ニテ八稍了下降シ $172 \mathrm{mg}$. トナルモ少 $20 \%$ ノ時ノ菌量ヨリ多シ。

酸素，消費量八菌量卜反對二酸素，濃度，增ス卜共二減少シ $40 \%$ ニテハ 1.6 c.c. 60 . $\%$ テ $1.1 \mathrm{ccc}$. ニシテ $80 \%$ ニテ $60 \%$ ト同樣 $1.1 \mathrm{ccc} .+リ 。$

コノ菌量, 發育キ示ス curve ト酸素消費量, curve 八動キ八前實驗 B.C.G.， 夫レト反對ニシテ.B.C.G. ニテハ酸素ノ濃度ノ增スト共二菌量八隇少シ酸素消費量ハ 增加シタルニ反シ鳥型結核菌, 場合八酸素，濃度/增加卜共二菌量八增加シ酸素消費 量八減少ス。

Table XXIII 八 timothy 菌き $20 \%$ 乃至 $80 \%$ /酸素分壓ノ下二培養シタル實驗二 シテ Experiment I ハ3540c.c. Jar チ用七 $20 \%$ ，酸素分壓下二試驗管 3 本き 培養七ル成績ニシテ 3 週後 manometer ハー59mm. チ示シ最初 $20.93 \%$ 郎チ $662 \mathrm{ccc}$ 
Table XXIII.

Analyses and oxygen requirement of timothy bacilli grown on glycerol broth in increased oxygen tension.

\begin{tabular}{|c|c|c|c|c|}
\hline No. of experiment & $\mathbf{I}$ & II & III & IV \\
\hline Planned percent. of oxygen & 20 & 40 & 60 & 80 \\
\hline Experimental material & Timothy & Timothy & Timothy & Timothy \\
\hline No. of days & 21 & 21 & 21 & 21 \\
\hline No. of tubes & 3 & 3 & 3 & 1 \\
\hline Net volume of Jar & 3540 & 3540 & 3440 & 1610 \\
\hline Manometer & -59 & -64 & -54 & -10 \\
\hline $\begin{array}{ll}\text { Barometer } & \\
& \text { Initial } \\
& \text { Final }\end{array}$ & $\begin{array}{l}755.6 \\
754.7\end{array}$ & $\begin{array}{l}755.2 \\
760.2\end{array}$ & $\begin{array}{l}760.8 \\
758.5\end{array}$ & $\begin{array}{l}756.4 \\
757.7\end{array}$ \\
\hline $\begin{array}{c}\text { Temperature } \\
\text { Initial } \\
\text { Final } \\
\end{array}$ & $\begin{array}{l}22 \\
23\end{array}$ & $\begin{array}{l}21 \\
23\end{array}$ & $\begin{array}{l}22 \\
21\end{array}$ & $\begin{array}{l}25 \\
29\end{array}$ \\
\hline $\begin{array}{ll}\text { Analyses } & \\
& \text { Initial } \mathrm{O}_{2} \\
& \text { Final } \mathrm{O}_{2}\end{array}$ & $\begin{array}{r}20.930 \\
0.701\end{array}$ & $\begin{array}{l}42.300 \\
21.201\end{array}$ & $\begin{array}{l}64.310 \\
47.000\end{array}$ & $\begin{array}{l}79.387 \\
68.811\end{array}$ \\
\hline $\begin{array}{ll}\begin{array}{l}\text { C.c. } \mathrm{O}_{2} \\
760 \mathrm{~mm}\end{array} & \text { at } \mathrm{O} \text { degree, } \\
& \text { Initial } \\
& \text { Final } \\
\end{array}$ & $\begin{array}{r}662 \\
20\end{array}$ & $\begin{array}{r}1267 \\
582\end{array}$ & $\begin{array}{l}1998 \\
1354\end{array}$ & $\begin{array}{r}1128 \\
945 \\
\end{array}$ \\
\hline $\mathrm{O}_{2}$ loss & 642 & 685 & 644 & 183 \\
\hline $\begin{array}{l}\text { Dry weight of bacilli in } \\
\text { mgs }\end{array}$ & 174.173 .162 & 229.215 .220 & 244.247 .202 & 207 \\
\hline Average & 169 & 221 & 231 & 207 \\
\hline $\begin{array}{c}\text { Consumed } \mathrm{O}_{2} \\
\text { Dry weight of bacilli }\end{array}$ & 1.3 & 1.0 & 1.0 & 0.9 \\
\hline
\end{tabular}

\section{Chart 15.}

The growth and consumed oxygen curve of timothy bacilli grown on glycerol broth in increased oxygen tension.

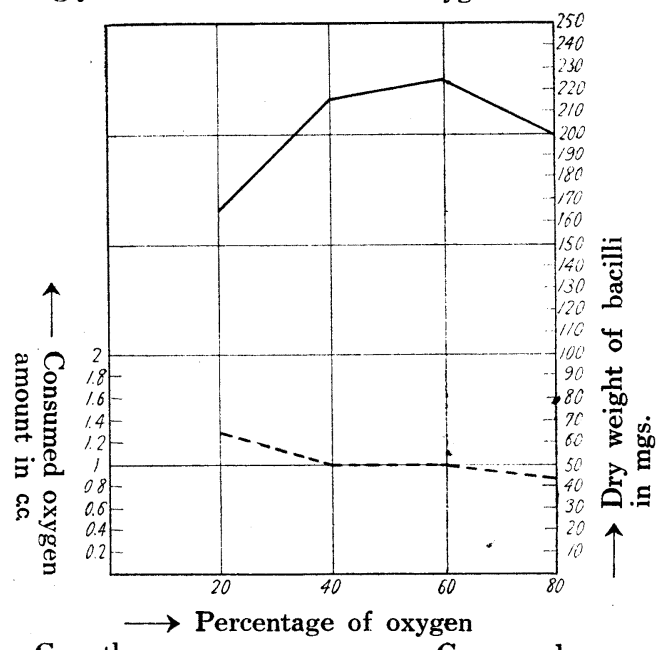

Growth curve.

..... Consumed oxygen curve. 
アリタル酸素ハ最後 $=0.701 \%$ 郎チ $20 \mathrm{ccc}$.トナリ消費量ハ $642 \mathrm{ccc}$. ニシテ發育菌量 ハ合 計 $494 \mathrm{mg}$ ナル故 $=1 \mathrm{mg}$.發有二要スル酸素量ハ1.3c.c.ナリ。Experiment II ハ3540 c.c. 容量, Jar キ用七 $40 \%$ 酸素分壓ノ下二試驗管 3 本テ培養セル成績ニシテ 3 週 後 manometer ハ $-64 \mathrm{~mm}$. キ示シ最初酸素 $42.300 \%$ 郎チ 1267 c.c. アリタルモノガ最 後二 $21.201 \%$ 郎于 $582 \mathrm{ccc}$. トナリ消費量ハ $685 \mathrm{ccc}$.ニシテ發育菌量八合計 $650 \mathrm{mg}$.ナル故 =1mg.發有二要スル酸素量ハ 1.0 c.c. ナリ。Experiment III ハ 3440 c.c. ノ容量ノJar 丹用七 $60 \%$ ，酸素分厚，下二試驗管 3 本丹培飬シタル成績ニシテ 3 週後 manometer ハ $-54 \mathrm{~mm}$ キ示シ最初酸素量 $64.310 \%$ 郎チ 1998 c.c.アリタルモノガ最後 $=47 \%$ 郎チ 1354c.c. トナリ消費量ハ 644c.c. ニシテ發育菌量 ハ合計 $680 \mathrm{mg}$.ナル故 $=1 \mathrm{mg}$.發育二要 スル酸素量ハ1.0c.aナリ。Experiment IV’、1610c.c.，容量，Jar キ用七 $80 \%$ ， 酸素分厘ノ下二試驗管 1 本き培養シタル成績ニシテ 3 週後 manometer ハ $-10 \mathrm{~mm}$. キ示シ最初 $79.387 \%$ 郎チ 1128 c.c. アリタル酸素 ハ最後二゙68.811\%郎チ 945 c.c.トナリ 消費量ハ $183 \mathrm{c} . \mathrm{c}$. ニシテ發育菌量ハ $202 \mathrm{mg}$ ナル故二 $1 \mathrm{mg}$ 發育二要スル酸素量ハ $0.9 \mathrm{ccc}$. ナリ。

以上, 關係尹 curve ニテ表ハス時ハ Chart 15 ノ如シ。

菌量八酸素ノ濃度, 增加スルト共二增シ $40 \%$ テ $216 \mathrm{mg}$. $60 \%$ ニ $226 \mathrm{mg}$.二薘 シ $80 \%$ 二テ稍了下降シ $202 \mathrm{mg}$.二低下スルモ少 $20 \%$ 時ノ菌量ヨリ多シ。

酸素消費量八反對二酸素，濃度，增加スルト共二減少シ $40 \%$ 二降下シ 1.0 c.c., 60 $\%=$ 同樣 1 c.c. ニシテ $80 \%$ ニラ 0.9 c.c. トナル。

以上ノ菌量ノ發育き示ス curve ト酸素消費量, curve ノ動キハ前實驗鳥型菌ノ場 合卜全ク同一ニシテ酸素, 濃度, 增加卜共二菌量八增シ酸素消費量八減少ス。

\section{第二項 酸素，低分壓二於ケル實驗}

此項二テ八酸素ノ分厭テ減少シ $5 \%$ 及ビ $10 \%$ トシ各種抗酸性菌き培養シ發育菌量 及ビ酸素消費量き測定セリ。Jar ノ容量ハ 3500 c.c. 內外ノモノキ用七タリ。今 Jar 二

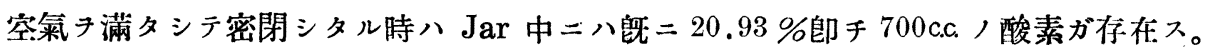
今 Jar 中ノ酸素/濃度キ $5 \%$ トル第メ二八酸素/含有量き 175 c.c.トスレバョキ故 Jar キ $570 \mathrm{~mm}$. 二減㻺シタル後 manometer，Zero ニナルマデ窒素キ滿タセリ。又酸素 ノ濃度き $10 \%$ トルニ八酸素ノ含有量キ 350 c.c.トスレバョキ故 Jar キ $380 \mathrm{~mm}$ 二減

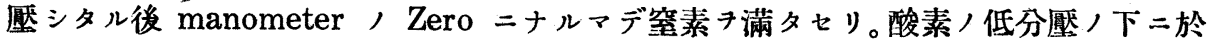
ケル費驗成績ハ Table XXIV 乃至 Table XXVII 二揭示七り。

Table XXIV 八人型結核菌青山 B, 上池四, 松本 5 \%及ビ $10 \%$ ，酸素分厔ノ下二 
Table XXIV.

Analyses and oxygen requirement of human tubercle bacilli (Aoyama B., Kamlike III., Matsumoto) grown on glycerol broth in decreased oxygen tension.

\begin{tabular}{|c|c|c|c|c|c|c|}
\hline No. of experiment & $\mathbf{I}$ & II & III & IV & $\mathbf{V}$ & VI \\
\hline $\begin{array}{c}\text { Planned percent. } \\
\text { of oxygen }\end{array}$ & 5 & 10 & 5 & 10 & 5 & 10 \\
\hline $\begin{array}{c}\text { Experimental } \\
\text { material }\end{array}$ & Aoyama B. & Aoyama B. & $\begin{array}{l}\text { Kamiike } \\
\text { III }\end{array}$ & $\begin{array}{l}\text { Kamiike } \\
\text { III }\end{array}$ & Matsumoto & Matsumoto \\
\hline No. of days & 21 & 21 & 21 & 21 & 21 & 21 \\
\hline No. of tubes & 2 & 2 & 2 & 2 & 2 & 2 \\
\hline $\begin{array}{r}\text { Net volume } \\
\text { of } \mathrm{Jar}\end{array}$ & 3560 & 3560 & 3610 & 3560 & 3560 & 3360 \\
\hline Manometer & -40 & -53 & -61 & -1 & -36 & -31 \\
\hline $\begin{array}{c}\text { Barometer } \\
\text { Initial } \\
\text { Final } \\
\end{array}$ & $\begin{array}{l}763.7 \\
752.5\end{array}$ & $\begin{array}{l}752.2 \\
760.1\end{array}$ & $\begin{array}{l}762.1 \\
766.4\end{array}$ & $\begin{array}{l}762.1 \\
766.4\end{array}$ & $\begin{array}{l}756.2 \\
757.5 \\
\end{array}$ & $\begin{array}{l}756.2 \\
757.5 \\
\end{array}$ \\
\hline $\begin{array}{c}\text { Temperature } \\
\text { Initial } \\
\text { Final } \\
\end{array}$ & $\begin{array}{l}23 \\
17\end{array}$ & $\begin{array}{l}16 \\
20\end{array}$ & $\begin{array}{l}22 \\
22 \\
\end{array}$ & $\begin{array}{l}22 \\
22\end{array}$ & $\begin{array}{l}23 \\
20\end{array}$ & $\begin{array}{l}.23 \\
20\end{array}$ \\
\hline $\begin{array}{l}\text { Analyses } \\
\text { Initial } \mathrm{O}_{2} \\
\text { Final } \mathrm{O}_{2}\end{array}$ & $\begin{array}{l}5.457 \\
0.697 \\
\end{array}$ & $\begin{array}{r}11.201 \\
4.523\end{array}$ & $\begin{array}{l}6.852 \\
1.152 \\
\end{array}$ & $\begin{array}{l}8.983 \\
1.694\end{array}$ & $\begin{array}{l}6.746 \\
3.305 \\
\end{array}$ & $\begin{array}{l}9.811 \\
3.668\end{array}$ \\
\hline $\begin{array}{c}\text { C.c. } \mathrm{O}_{2} \text { at } \mathrm{O} \\
\text { degree, } 760 \mathrm{~mm} \\
\text { Initial } \\
\text { Final }\end{array}$ & $\begin{array}{r}162 \\
21 \\
\end{array}$ & $\begin{array}{l}367 \\
136 \\
\end{array}$ & $\begin{array}{r}225 \\
35 \\
\end{array}$ & $\begin{array}{r}289 \\
55 \\
\end{array}$ & $\begin{array}{l}215 \\
101 \\
\end{array}$ & $\begin{array}{l}281 \\
107\end{array}$ \\
\hline $\mathrm{O}_{2}$ loss & 141 & 231 & 190 & 234 & 114 & 174 \\
\hline $\begin{array}{l}\text { Dry weight of } \\
\text { bacilli in mgs }\end{array}$ & 52. 49 & 73. 75 & 76.71 & 77.73 & 55. 50 & 62.59 \\
\hline Average & 50 & 74 & 73 & 75 & 52 & 60 \\
\hline $\begin{array}{c}\text { Consumed } \mathrm{O}_{2} \\
\begin{array}{c}\text { Dry weight of } \\
\text { bacilli }\end{array}\end{array}$ & 1.6 & 1.7 & 1.3 & 1.6 & 1.2 & 1.6 \\
\hline
\end{tabular}

培養セル賽驗ナリ。Experiment I ハ3560c.c. ノ容量ノJar 尹用七青山 B. ノ試驗管 2 本き $5 \%$ ノ酸素分厣ノ下二培養七ル成績ニシテ 3 週後 manometer ハ $-40 \mathrm{~mm}$. キ示 シ最初 $5.457 \%$ 郎チ 162 c.c. アリタルモノガ最後 $=0.697 \%$ 郎チ 21 c.c. トナリ消費量八 $141 \mathrm{ccc}$. ニシテ發有菌量ハ合計 $91 \mathrm{mg}$. ナル故 $=1 \mathrm{mg}$. 發有二要スル酸素量ハ $1.6 \mathrm{ccc}$.リリ。

Experiment II ハ3560c.c.容量，Jar キ用七青山B 試驗管 2 本き $10 \%$ /酸素 分厘ノ下二培養七ル成績ニシテ 3 週後 manometer ハー $53 \mathrm{~mm}$. キ示シ最初 $11.201 \%$ 郎チ 367 c.c. アリタル酸素八最後二 $4.523 \%$ 郎チ 136 c.c. トナリ消費量ハ 231 c.c.ニシテ發 育菌量ハ合計 $138 \mathrm{mg}$.ナル故二 $1 \mathrm{mg}$.發育二要スル酸素量ハ 1.7 c.c.ナリ。Experiment

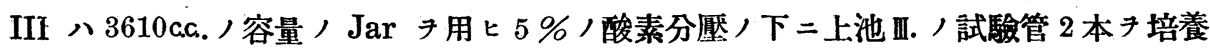
シタル成績ニシテ 3 週後 Manometer ハ $-61 \mathrm{~mm}$. キ示シ最初 $6.852 \%$ 郎チ 225 c.c. ア リタル酸素ハ最後 $=1.152 \%$ 郎チ $35 c . c$. トナリ消費量ハ $190 \mathrm{ccc}$. ニシテ發有菌量ハ 137 
mg. ナル故 $=1 \mathrm{mg}$. 發有二要スル酸素量ハ1.3c.c.ナリ。Experiment IVハ3560c.c.， 容量,Jar タ用七 $10 \%$ 酸素分厭ノ下二上池四. 八試驗管き 2 本培養七ル成績ニシテ 3 週後 manometer $-1 \mathrm{~mm}$. キ示シ最初 $8.983 \%$ 郎チ $289 \mathrm{ccc}$. リタル酸素ハ最後二 $1.694 \%$ 郎于 55 c.c. トナリ消費量ハ 234 c.c. ニシテ發育菌量ハ合計 $140 \mathrm{mg}$.ナル故 $=1 \mathrm{mg}$. 發育二要スル酸素量ハ1.6c.c.ナリ。Experiment Vハ3560c.c. /容量Ｊar キ用七 $5 \%$ /酸素分厩ノ下二松本ノ試驗管 2 本キ培養七ル成績ニシテ 3 週後 manometer 八 $-36 \mathrm{~mm}$. ヨ示シ最初 $6.746 \%$ 郎チ 215 c.c. アリタル酸素八最後 $=3.305 \%$ 郎チ 101 c. ナリ消費量ハ $114 \mathrm{ccc}$ 。ニシテ發有菌量ハ合計 $95 \mathrm{mg}$.ナル故二 $1 \mathrm{mg}$.發有二要スル酸素量 ハ1.2c.c.ナリ。Experiment VI ハ3360c.c.，Jar チ用七 $10 \%$ ノ酸素分壓ノ下二松 本ノ試驗管き 2 本培養セル成績ニシテ 3 週後 manometer ハー $31 \mathrm{~mm}$. タ示シ最初 $9.811 \%$ 郎チ 281 c.c. アリタル酸素 ハ最後 $=3.668 \%$ 郎チ 107 c.c.トナリ消費量ハ 174 c.c.

Table XXV.

Analyses and oxygen requirement of bovine tubercle bacilli (No. 3, No. 6, No. 12) grown on glycerol broth in decreased oxygen tension.

\begin{tabular}{|c|c|c|c|c|c|c|}
\hline No. of experiment & I & II & III & IV & $\mathrm{V}$ & VI \\
\hline $\begin{array}{c}\text { Planned percent. } \\
\text { of oxygen }\end{array}$ & 5 & 10 & 5 & 10 & 5 & 10 \\
\hline $\begin{array}{c}\text { Experimental } \\
\text { material }\end{array}$ & $\begin{array}{c}\text { Bovine } \\
\text { No. } 3\end{array}$ & $\begin{array}{r}\text { Bovine } \\
\text { No. } 3\end{array}$ & $\begin{array}{r}\text { Bovine } \\
\text { No. } 6\end{array}$ & $\begin{array}{r}\text { Bovine } \\
\text { No. } 6\end{array}$ & $\begin{array}{l}\text { Bovine } \\
\text { No. 12 }\end{array}$ & $\begin{array}{l}\text { Bovine } \\
\text { No. } 12\end{array}$ \\
\hline No. of days & 21 & 21 & 21 & 21 & 21 & 21 \\
\hline No. of tubes & 2 & 2 & 1 & 2 & 1 & 1 \\
\hline $\begin{array}{c}\text { Net volume of } \\
\text { Jar }\end{array}$ & 3360 & 3560 & 8630 & 3360 & 3580 & 3380 \\
\hline Manometer & -5 & -35 & -62 & -35 & -32 & -7 \\
\hline $\begin{array}{c}\text { Barometer } \\
\text { Initial } \\
\text { Final } \\
\end{array}$ & $\begin{array}{l}763.7 \\
752.5\end{array}$ & $\begin{array}{l}749.8 \\
756.8 \\
\end{array}$ & $\begin{array}{l}759.4 \\
759.9 \\
\end{array}$ & $\begin{array}{l}760.1 \\
762.6 \\
\end{array}$ & $\begin{array}{l}752 \\
751.5 \\
\end{array}$ & $\begin{array}{l}752 \\
751.5\end{array}$ \\
\hline $\begin{array}{c}\text { Temperature } \\
\text { Initial } \\
\text { Final } \\
\end{array}$ & $\begin{array}{l}23 \\
17\end{array}$ & $\begin{array}{l}23 \\
24\end{array}$ & $\begin{array}{l}24 \\
21\end{array}$ & $\begin{array}{l}21 \\
16\end{array}$ & $\begin{array}{l}24 \\
27.5 \\
\end{array}$ & $\begin{array}{l}24 \\
27.5\end{array}$ \\
\hline $\begin{array}{l}\text { Analyses } \\
\text { Initial } \mathrm{O}_{2} \\
\text { Final } \mathrm{O}_{2}\end{array}$ & $\begin{array}{l}6.170 \\
1.222\end{array}$ & $\begin{array}{l}8.691 \\
1.686\end{array}$ & $\begin{array}{l}5.783 \\
4.272\end{array}$ & $\begin{array}{l}7.824 \\
3.228\end{array}$ & $\begin{array}{l}6.455 \\
3.758 \\
\end{array}$ & $\begin{array}{l}9.431 \\
7.062\end{array}$ \\
\hline $\begin{array}{c}\text { C.c. } \mathrm{O}_{2} \text { at } \mathrm{O} \\
\text { degree, } 760 \mathrm{~mm} \\
\text { Initial } \\
\text { Final }\end{array}$ & $\begin{array}{r}186 \\
37 \\
\end{array}$ & $\begin{array}{r}270 \\
53 \\
\end{array}$ & $\begin{array}{l}187 \\
128\end{array}$ & $\begin{array}{r}237 \\
96 \\
\end{array}$ & $\begin{array}{l}204 \\
113\end{array}$ & $\begin{array}{l}279 \\
205\end{array}$ \\
\hline $\mathrm{O}_{2}$ loss & 149 & 217 & 59 & 141 & 91 & $7 \overline{4}$ \\
\hline $\begin{array}{l}\text { Dry weight of } \\
\text { bacilli in mgs. }\end{array}$ & 53. 49 & 75.85 & 40 & 46. 43 & 90 & 92 \\
\hline Average & 51 & 80 & 40 & 44 & 90 & 92 \\
\hline 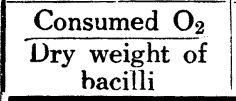 & 1.5 & 1.5 & 1.7 & 1.8 & 1 & 0.9 \\
\hline
\end{tabular}


ニシテ發育菌量ハ合計 $111 \mathrm{mg}$. ナル故 $=1 \mathrm{mg}$. 發育二要スル酸素量ハ $1.6 \mathrm{ccc}$. ナ。

Table XXV，牛型結核菌 No. 3 , No. 6, No. 12 于酸素，低分厘，下二培飬七 ル實煥ナリ。Experiment I ハ 3360 c.c. ，容量，Jar キ用七 $5 \%$ ，酸素分厭，下二 No. 3 人試驗管 2 本子培養七ル成績ニシテ 3 週後 manometer ハー5mm. キ示シ最初 $6.17 \%$ 郎チ $186 \mathrm{ccc}$ 、アリタル酸素ハ最後二 $1.222 \%$ 郎チ 37 c.c. トナリ消費量ハ $149 \mathrm{ccc}=$ シテ發育菌量八合計 $92 \mathrm{mg}$.ナル故 $=1 \mathrm{mg}$.發育二要スル酸素量ハ 1.5 c.c.ナリ。Experi-

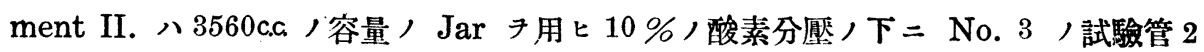
本き培養セル成績ニシテ 3 週後 manometer ハ $-35 \mathrm{~mm}$. キ示シ最初 $8.691 \%$ 郎チ 270 c.c. アリタル酸素八最後二 $1.686 \%$ 郎チ 53 c.c. トナリ消費量ハ 217 c.c. 二シテ發有菌量 八合計 $150 \mathrm{mg}$.ナル故 $=1 \mathrm{mg}$. 發市二要スル酸素量ハ1.5c.c. ナリ。Experiment III 八 3630 c.c. ，容量，Jar 尹用七 $5 \%$ /酸素分壓，下二 No. 6 人試驗管き 1 本培養七ル成 績ニシテ 3 週後 manometer ハー62mm. キ示シ最初 $5.783 \%$ 郎チ 187 c.c.アリタル酸 素八最後 $=4.272 \%$ 郎チ 128 c.c. トナリ消費量ハ 59 c.c. ニシテ發育菌量ハ $35 \mathrm{mg}$.ナル故 $=1 \mathrm{mg}$.發有二要スル酸素量ハ 1.7 c.c.ナリ。Experiment IV ハ 3360 c.c. ）容量，Jar

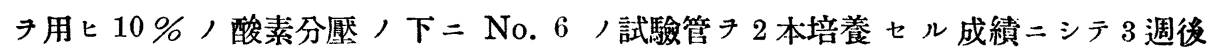
manometer ハー $35 \mathrm{~mm}$. キ示シ最初 $7.824 \%$ 郎チ 237 c.c.アリタル酸素ハ最後 $=3.228$ \%郎チ $96 \mathrm{ccc}$.トナリ消費量ハ $141 \mathrm{ccc}$.ニシテ發有菌量ハ合計 $79 \mathrm{mg}$.ナル故 $=1 \mathrm{mg}$.發有二 要スル酸素量ハ1.8c.c.ナリ。

Experiment V 八 $3580 \mathrm{ccc}$ ，容量，Jar チ朋七 $5 \%$ /酸素分壓 下二 No. 12 ， 試驗管 1 本培養セル成績ニシテ 3 週後 manometer ハー $32 \mathrm{~mm}$. キ示シ最初 $6.455 \%$ 郎チ 204 c.c. アリタル酸素ハ最後二 $3.758 \%$ 郎チ 113 c.c. トナリ消費量ハ $91 \mathrm{mg}$.ニシテ發 育菌量ハ $85 \mathrm{mg}$.ナル故二 $1 \mathrm{mg}$.發育二要スル酸素量ハ1c.c.ナリ。Experiment VI 八

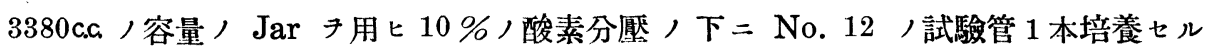
成績ニシテ 3 週後 manometer ハー7mm. チ示シ最初 $9.431 \%$ 郎チ 279 c.c. アリタル 酸素ハ最後二 $7.062 \%$ 郎チ 205 c.c. トナリ消費量ハ 74 c.c. ニシテ發有菌量ハ $87 \mathrm{mg}$.ナル 故 $=1 \mathrm{mg}$. 發育二要スル酸素量ハ $0.9 \mathrm{ccc}$.ナリ。

Table XXVI 八牛型結核菌 No. 14, 北研及ビ B.C.G. キ $5 \%$ 及ビ $10 \%$ /酸素分 壓ノ下二培養セル實驗ナリ。

Experiment I 八3460c.c。 ノ容量, Jar 尹用 ヒ牛型結核菌 No. 14 人試驗管 2 本 キ $5 \%$ 八酸素分壓,下二培養セル成績ニシテ 3 週後 manometer ハ $-3 \mathrm{~mm}$. チ示シ 最初 $6.133 \%$ 郎チ 192 c.c. アリタル酸素八最後=0.115\%郎チ 3 c.c. トナリ消費量ハ 189 
Table XXV1

Analyses and oxygen requirement of bovine tubercle bacilli (No. 14, Hokken) and B. C. G. grown on glycerol broth in decreased oxygen tension.

\begin{tabular}{|c|c|c|c|c|c|c|}
\hline No. of experiment & I & II & III & IV & $\mathrm{V}$ & VI \\
\hline $\begin{array}{c}\text { Planned percent. } \\
\text { of oxygen }\end{array}$ & 5 & 10 & 5 & 10 & 5 & 10 \\
\hline $\begin{array}{c}\text { Experimeittal } \\
\text { material }\end{array}$ & $\begin{array}{l}\text { Bovine } \\
\text { No. } 14\end{array}$ & $\begin{array}{l}\text { Borine } \\
\text { No. } 14\end{array}$ & $\begin{array}{l}\text { Bo ine } \\
\text { Hokken }\end{array}$ & $\begin{array}{l}\text { Bovine } \\
\text { Hokt en }\end{array}$ & B. C. G. & B. C. G. \\
\hline No. of days & 21 & 21 & 21 & 21 & 21 & 21 \\
\hline No. of tubes & 2 & 2 & 1 & 1 & 1 & 2 \\
\hline $\begin{array}{c}\text { Net volume of } \\
\text { Jar }\end{array}$ & $: 3460$ & 3460 & 3480 & 3080 & 3580 & 3610 \\
\hline Manometer & -3 & -7 & -10 & -10 & -37 & -68 \\
\hline $\begin{array}{c}\text { Barometer } \\
\text { Initial } \\
\text { Final }\end{array}$ & $\begin{array}{l}758.9 \\
765.5\end{array}$ & $\begin{array}{l}759.6 \\
755.2\end{array}$ & $\begin{array}{l}758.7 \\
759.4\end{array}$ & $\begin{array}{l}769.8 \\
747.8\end{array}$ & $\begin{array}{l}759.3 \\
758\end{array}$ & $\begin{array}{l}758.5 \\
763.8\end{array}$ \\
\hline $\begin{array}{c}\text { Temperature } \\
\text { Initial } \\
\text { Final }\end{array}$ & $\begin{array}{l}21 \\
22\end{array}$ & $\begin{array}{l}22 \\
22\end{array}$ & $\begin{array}{l}18 \\
23\end{array}$ & $\begin{array}{l}24 \\
30\end{array}$ & $\begin{array}{l}13 \\
22\end{array}$ & $\begin{array}{l}21 \\
19\end{array}$ \\
\hline $\begin{array}{l}\text { Analyses } \\
\text { Initial } \mathrm{O}_{2} \\
\text { Final } \mathrm{O}_{2}\end{array}$ & $\begin{array}{l}6.133 \\
0.115\end{array}$ & $\begin{array}{r}10.337 \\
3.400\end{array}$ & $\begin{array}{l}5.797 \\
0.886\end{array}$ & $\begin{array}{l}8.412 \\
0.118\end{array}$ & $\begin{array}{l}6.165 \\
3.475\end{array}$ & $\begin{array}{r}10.129 \\
0.382\end{array}$ \\
\hline $\begin{array}{c}\text { C.c. } \mathrm{O}_{2} \text { at } \mathrm{O} \\
\text { degree, } 760 \mathrm{~mm} \\
\text { Initial } \\
\text { Final }\end{array}$ & $\begin{array}{r}192 \\
:\end{array}$ & $\begin{array}{l}327 \\
103\end{array}$ & $\begin{array}{r}175 \\
27\end{array}$ & $\begin{array}{r}157 \\
2\end{array}$ & $\begin{array}{l}198 \\
106\end{array}$ & $\begin{array}{r}328 \\
11\end{array}$ \\
\hline $\mathrm{O}_{2}$ loss & 189 & 224 & 148 & 155 & 92 & 317 \\
\hline $\begin{array}{l}\text { Dry weight of } \\
\text { bacilli in mgs }\end{array}$ & 64.59 & S2. 78 & 115 & 120 & 50 & 80.73 \\
\hline Average & 61 & 80 & 115 & 120 & 50 & 76 \\
\hline 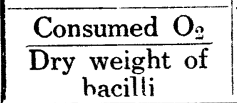 & 1.6 & 1.4 & 1.3 & 1.3 & 2 & 2.2 \\
\hline
\end{tabular}

c.c. ニ シテ發有菌量八合計 $113 \mathrm{mg}$. ナル故二 $1 \mathrm{mg}$. 發育二要スル酸素量ハ $1.6 \mathrm{ccc}$ 。ナリ Experiment II ハ 3460 c.c. ノ容量Ｊar キ用七牛型結核菌 No. 14 人試驗管 2 本尹 $10 \%$ 酸素分厴,下二培養七ル成績ニシテ 3 週後 manometer ハ $-7 \mathrm{~mm}$. キ示シ最 初 $10.337 \%$ 郎于 327 c.c. アリタル酸素ハ最後二 $3.4 \%$ 郎チ 103 c.c. トナリ消費量ハ 224 c. . ニシテ發育菌量八合計 $150 \mathrm{mg}$. ナル故二 $1 \mathrm{mg}$. 發育二要スル酸素量ハ $1.4 \mathrm{ccc}$. リ。 Experiment III ハ3480c.c. /容量, Jar 尹用七牛型結核菌北研/試驗管 1 本丹 $5 \%$ ノ酸素分厭ノ下二培養七ル成績ニシテ 3 週後 manometer ハ $-10 \mathrm{~mm}$. キ示シ最初 $5.797 \%$ 郎チ 175 c.c.アリタル酸素 ハ最後テ0.8860\%郎チ 27 c.c. トナリ消費量ハ 148 c.c. ニシテ發有菌量ハ $110 \mathrm{mg}$. ナル故 $=1 \mathrm{mg}$. 發有二要スル酸素量ハ1.3c.c.ナリ。Experi-

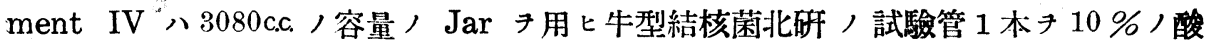
素分厴，下二培養七ル成績ニシテ 3 週後 manometer ハ $-10 \mathrm{~mm}$. キ示シ最初 8.412 
\%郎チ 157 c.c. アリタル酸素ハ最後二 $0.118 \%$ 郎チ 2 c.c. トナリ消費量ハ 155 c.c. ニシテ發 有菌量ハ $115 \mathrm{mg}$. ナル故二 $1 \mathrm{mg}$. 發育二要スル酸素量ハ 1.3c.c.ナリ。Experiment V ハ 3580 c.c. ，容量，Jar キ用七 B.C.G. ノ試驗管 1 本き $5 \%$ /酸素分壓〉下二培養七 ル成績ニシテ 3 週後 manometer ハー $37 \mathrm{~mm}$. キ示シ最初 $6.165 \%$ 郎チ 198 c.c.アリタ ル酸素ハ最後二 $3.475 \%$ 郎チ 106 c.c. トナリ消費量ハ $92 \mathrm{ccc}$. ニシテ發充菌量ハ $45 \mathrm{mg}$.ナ ル故 $=1 \mathrm{mg}$. 發有二要スル酸素量ハ 2 c.c. ナリ。Experiment VI ハ3610c.c. /容量， Jar キ用七 B.C.G. 八試驗管 2 本き $10 \%$ /酸素分厴ノ下 $=$ 培養七ル成績ニシテ 3 週 後 manometer ハ $-68 \mathrm{~mm}$. キ示シ最初 $10.129 \%$ 郎チ 328 c.c. アリタル酸素八最後二 $0.382 \%$ 郎于 11 c.c. トナリ消費量ハ 317 c.c. ニシテ發者菌量八合計 $143 \mathrm{mg}$. ナル故二 1 $\mathrm{mg}$. 發有二要入ル酸素量ハ 2.2 c.c. ナリ。

Table XXVII.

Analyses and oxygen requirement of avian tubercle bacilli and timothy bacilli grown on glycerol broth in decreased oxygen tension.

\begin{tabular}{|c|c|c|c|c|}
\hline No. of experiment & I & II & III & IV \\
\hline Planned percent. of oxygen & 5 & 10 & 5 & 10 \\
\hline Experimental material & Avian type & Avian type & Timothy & Timothy \\
\hline No. of days & 21 & 21 & 21 & 21 \\
\hline No. of tubes & 1 & 1 & 1 & 1. \\
\hline Net volume of Jar & 3580 & 3630 & 3480 & 3630 \\
\hline Manometer & -1 & -36 & -18 & -70 \\
\hline $\begin{array}{cl}\text { Barometer } & \begin{array}{l}\text { Initial } \\
\text { Final }\end{array} \\
\end{array}$ & $\begin{array}{l}752 \\
751.5 \\
\end{array}$ & $\begin{array}{l}752 \\
751.5\end{array}$ & $\begin{array}{r}749.3 \\
763.8 \\
\end{array}$ & $\begin{array}{l}763.8 \\
763.1 \\
\end{array}$ \\
\hline $\begin{array}{r}\text { Temperature } \\
\text { Initial } \\
\text { Final }\end{array}$ & $\begin{array}{c}24 \\
27.5 \\
\end{array}$ & $\begin{array}{c}24 \\
27.5 \\
\end{array}$ & $\begin{array}{l}13 \\
19\end{array}$ & $\begin{array}{r}18 \\
17 \\
\end{array}$ \\
\hline $\begin{array}{ll}\text { Anaiyses } & \text { Initial } \mathrm{O}_{2} \\
& \text { Final } \mathrm{O}_{2} \\
\end{array}$ & $\begin{array}{l}6.121 \\
0.112 \\
\end{array}$ & $\begin{array}{l}9.677 \\
0.364\end{array}$ & $\begin{array}{l}6.284 \\
0.117\end{array}$ & $\begin{array}{l}7.567 \\
\mathbf{2 . 4 6 6} \\
\end{array}$ \\
\hline 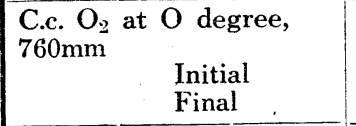 & $\begin{array}{r}192 \\
2 \\
\end{array}$ & $\begin{array}{r}310 \\
11 \\
\end{array}$ & $\begin{array}{r}203 \\
2 \\
\end{array}$ & $\begin{array}{r}254 \\
-75 \\
\end{array}$ \\
\hline $\mathrm{O}_{2} \operatorname{loss}$ & 190 & 299 & 201 & 179 \\
\hline $\begin{array}{l}\text { Dry weight of bacilli in } \\
\text { mgs. }\end{array}$ & 124 & 170 & 145 & 150 \\
\hline$\frac{\text { Consumed } \mathrm{O}_{2}}{\text { Dry weight of bacilli }}$ & 1.6 & 1.8 & 1.4 & 1.2 \\
\hline
\end{tabular}

Table XXVII 八鳥型結核菌及ビ timothy 菌き5\%及ビ $10 \%$ 酸素分㕄ノ下二培 養セル實驗ナリ。

Experiment I ハ3580c.c. ノ容量Ｊar キ用七鳥型結核菌ノ試驗管 1 本キ $5 \%$ 酸 
素分厴ノ下゙培養セル成績ニシテ 3 週後 manometer ハ $-1 \mathrm{~mm}$. キ示シ最初 $6.121 \%$ 郎チ 192 c.c. アリタル酸素ハ最後二 $0.112 \%$ 郎チ 2 c.c. トナリ消費量ハ 190 c.c. ニシテ發有 菌量ハ $119 \mathrm{mg}$. ナル故 $=1 \mathrm{mg}$. 發有二要スル酸素量ハ1.6c.c.ナリ。Experiment II 八 3630 c.c. ，容量，Jar キ用七鳥型結核菌ノ試驗管 1 本丹 $10 \%$ ，酸素分厚ノ下二培養 七ル成績ニシテ 3 週後 manometer ハー36mm. チ示シ最初 $9.677 \%$ 郎チ $310 \mathrm{cccc}$ ア リタル酸素 ハ最後二 $0.364 \%$ 郎チ 11 c.c. トナリ消費量ハ 299 c.c. ニシテ發有菌量ハ 165 $\mathrm{mg}$. ナル故 $=1 \mathrm{mg}$. 發有二要スル酸素量ハ $1.8 \mathrm{ccc}$.ナリ。

Experiment III ハ 3480 c.c. /容量, Jar キ用七 timothy 菌ノ試驗管キ 1 本 $5 \%$ 八酸素分厴,下二培養七ル成績二シテ 3 週後 manometer ハ $-18 \mathrm{~mm}$. キ示シ最初 $6.284 \%$ 郎チ 203 c.c. アリタル酸素八最後二 $0.117 \%$ 郎チ 2 c.c. トナリ消費量ハ 201 c.c. $=$ シテ發有菌量ハ $140 \mathrm{mg}$. ナル故二 $1 \mathrm{mg}$. 發有二要スル酸素量ハ 1.4 c.c.ナリ。

Experiment IV ハ3630c.c. /容量, Jar 尹用七 timothy 菌ノ試驗管 1 本 $10 \%$ ノ酸素分厴，下二培養七ル成績ニシテ 3 用後 manometer ハ $-70 \mathrm{~mm}$. キ示シ最初 $7.567 \%$ 郎チ 254 c.c.アリタル酸素ハ最後二 $2.466 \%$ 師チ 75 c.c. トナリ消費量ハ 179 c.c. $=$ シテ發有菌量ハ $145 \mathrm{mg}$. ナル故二 $1 \mathrm{mg}$. 墢育二要スル酸素量ハ 1.2 c.c.ナリ。

以上酸素，低分暦，下二於ケル實驗き總括スレバ㻐育菌量八人型及ビ牛型結核菌二 於テハ $20 \%$ 乃至 $40 \%$ 旅有菌量ヨリ全テ少ナシ。又 $10 \%$ 卜 $60 \%$ ト比較スル時八 青川Bト牛型菌No. 3 チ除キテハ殆ド.大差ナシ。又 $5 \%$ ト $80 \%$ ト比較スル時ハ人 型菌上池田. 及ビ松本，牛型菌 No. 3 , No. 6 八 $80 \%$ /菌量少ナキモ其他八大差ナシ。 而シテ $5 \%$ 菌量ハ $10 \%$ / 菌量ヨリ全テ少ナシ。

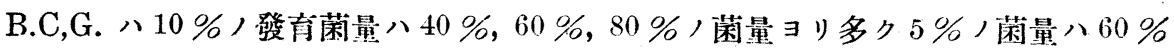
及ビ $80 \%$ リ多シ。

鳥型結核菌及ビ timothy 菌ノ弡南菌量八酸素ノ高分壓ノ全テノモノョリ少ナシ。

及 $1 \mathrm{mg}$. 發育二要スル酸素消費量， B.C.G. 尹除ク全テノ菌キ通ジ 0.9 c.c. 乃至 1.8 c.c. 間二在リテ $20 \%$ 乃至 $40 \%$ ，間二於ヶルモ，ト大差ナシ。唯 B.C.G. 八 2c.c. 乃至 2.2c.c. ニシテ他ノ抗酸性菌归酸素消費量多シ。

\section{第四章 總括及ビ考察}

前章第三節ノ第一項及ビ第二項，實驗成績 ノ結果タ一括シテ表示スレバ Table XXVIII 及ビ Table XXIX，如シ。

Table XXVIII ハ5\%乃至 $80 \%$ ，酸素，濃度下二於ケル各種抗酸性菌ノ發者菌 
Table XXVIII.

The dry weight of acid-fast bacilli grown on glycerol broth in different oxygen percentage for three weeks.

$\left\{\begin{array}{|l|r|r|r|r|r|r|}\hline \text { Percentage of oxygen } & 5 & 10 & 20 & 40 & 60 & 80 \\ \hline \text { Huhman tubercle bacilli (Aoyama B.) } & 45 & 69 & 140 & 145 & 103 & 50 \\ \hline \text { Huhman tubercle bacilli (Kamiike III.) } & 68 & 70 & 75 & 85 & 75 & 25 \\ \hline \text { Huhman tubercle bacilli (Matsumoto) } & 47 & 55 & 72 & 91 & 50 & 30 \\ \hline \text { Average } & 53 & 65 & 96 & 107 & 76 & 35 \\ \hline \text { Bovine tubercle bacilli (No. 3) } & 46 & 75 & 136 & 152 & 91 & 75 \\ \hline \text { Bovine tubercle bacilli (No. 6) } & 35 & 39 & 50 & 58 & 40 & 25 \\ \hline \text { Bovine tubercle bacilli (No. 12) } & 85 & 87 & 126 & 135 & 70 & 50 \\ \hline \text { Bovine tubercle bacilli (No. 14) } & 56 & 75 & 115 & 139 & 67 & 55 \\ \hline \text { Bovine tubercle bacilli (Hokken) } & 110 & 115 & 128 & 131 & 120 & 94 \\ \hline \text { Average } & 66 & 78 & 111 & 123 & 79 & 59 \\ \hline \text { B. C. G. } & 45 & 70 & 72 & 50 & 36 & 26 \\ \hline \text { Avian tubercle bacilli } & 119 & 165 & 171 & 175 & 180 & 172 \\ \hline \text { Timothy bacilli } & 140 & 145 & 164 & 216 & 226 & 202 \\ \hline\end{array}\right.$

量き表示シタルモノニシテ人型結核菌青山 B., 上池四, 松本ノ發育狀態き觀察スル $=5$ $\%$ \%リ酸素ノ濃度ノ增ス卜共二次第二發育菌量增加シ $40 \%$ ニテ最大ニシテ $60 \%=$ テ低下シ $80 \%$ 二テ最低二達ス。之等三種, 人型結核菌, 本均發有菌量キ求ムレバ $5 \%$ ニテ $53 \mathrm{mg} ., 10 \%$ ニ $65 \mathrm{mg} ., 20 \%$ テ $96 \mathrm{mg}$., $40 \%$ ニ $107 \mathrm{mg} ., 60 \%$ ニ $76 \mathrm{mg}$, $80 \%=$ テ $35 \mathrm{mg}$. トナル。又牛型結核菌 No. 3 , No. 6 , No. 12 , No. 14 , 北研ノ五種類 ノ發育狀態キ見ル二人型結核菌同樣 $5 \%$ ヨリ酸素,濃度,增加スルト共二次第二菌量 モ增加シ $40 \%$ ニ最高二達シ $60 \%$ ヨ $80 \%$ 二到り低下入。之等五種類, 牛型結核菌 ノ發育菌量ノ本均値尹求ムレバ $5 \%$ ニ $66 \mathrm{mg} ., 10 \%$ ニ $78 \mathrm{mg} ., 20 \%$ = $111 \mathrm{mg}$., $40 \%$ ニ $123 \mathrm{mg} ., 60 \%$ ニ $79 \mathrm{mg}$., $80 \%$ ニテ $59 \mathrm{mg}$. ナリ。人型結核菌及ビ 牛型結 核菌, 發育菌量ノ本均值 curve 二テ表ハセバ Chart 16 ノ如シ。實線ハ人型結核菌 ノ發育キ示ス curve ニシテ點線ハ牛型結核菌ノ發育チ示ス curve チ表ハス師チ兩型 ノ發育狀態二八著シキ差異ナシ。然レ共兩型共毒力，比較的弱キ菌例へバ青山 B, No. 3, No. 14, 北研八發育良好ナルガ如シ。

B.C.G. 八發有狀態ハ他ノ結核菌ノソレト狀態 ヨ異ニシ $10 \%$ 乃至 $20 \%$ ニ最高二 澾シソレョリ酸素, 濃度, 增加卜共二發有菌量 減ズ郎チ酸素, 最適濃度ハ10\%乃 至 $20 \%$ シテソレ以上ハ寧口有害ナリ。

次二鳥型結核菌，發有狀態 胃ルニ5\%ヨリ酸素，濃度，增加スルト共二次第二發 南菌量习增 シ $60 \%$ 二テ最高二達シ $80 \%$ 二テモ劣 $170 \mathrm{mg}$. ニシテ $20 \%$, 發有茵量 
Chart 16.

The growth curve of human and bovine tubercle bacilli grown on glycerol broth in the different oxygen percentage.

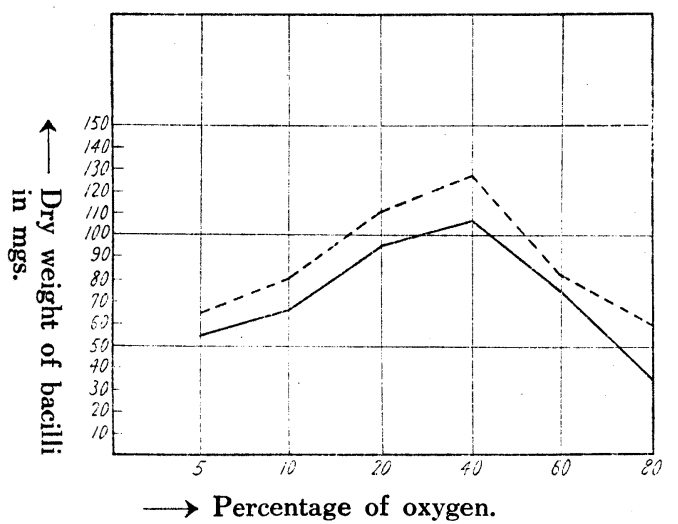

$\longrightarrow$ Percentage of oxygen.

Growth curve of human tubercle bacilli.

- Growth curve of bovine tubercle bacilli.

リ多シ。郎チ酸素ノ最適濃度ハ $60 \%$ 乃至 $70 \%$ \%。

又 timothy 菌, 發有狀態見ル二鳥型結核菌同樣酸素, 濃度, 增加卜共二次第二

Chart 17.

The growth curve of tubercle bacilli and B. C. G. and avian tubercle bacilli and timothy bacilli grown on glycerol broth in the different oxygen percentage.
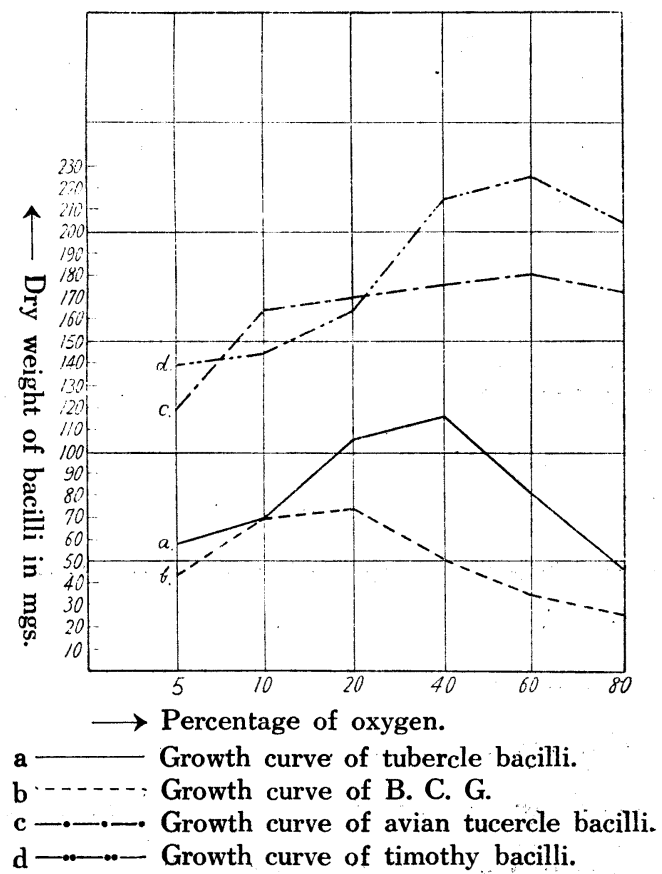
增加シ $60 \%$ ニテ最高二達シ $80 \%$ ニテモ尙 $202 \mathrm{mg}$. ニシテ $20 \%$ 發有菌量ヨリ多シ。 郎于酸素, 最適濃度ハ $60 \%$ 乃至 $70 \%$ サ。

今人型結核菌及ビ牛型結核菌, 發有菌量, 本均值 尹求ムル時ハ $5 \%$ ニ $59 \mathrm{mg}$. $10 \%$ ニ $70 \mathrm{mg} ., 20 \%$ $20103 \mathrm{mg} ., 40 \%$ ニ $115 \mathrm{mg} ., 60 \%$ テ $77 \mathrm{mg} ., 80 \%$ = 47 mg. ナリ今之き curve 二テ表ハシ B.C.G., 鳥型結核菌, timothy 菌， growth curve ト比較スル時ハ Chart 17 ，如シ。 a 線ハ結核菌ノ發育示ス curve, b 線ハ B.C.G.

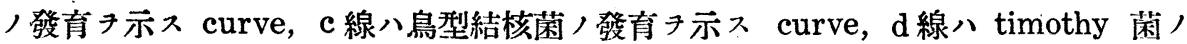
發有キ示ス curve キ表ハス。郎チ鳥型結核菌及ビ timothy 菌, curve ハ $80 \%=$ テ最高ニテ結核茵ハ最高 $40 \%$ ，B.C.G. 八最高 $20 \%$

Tabie XXIX.

The consumed oxygen amount aquire per 1mg. growth (in dry weight) of acid-fast bacilli grown on giycerol broth in different oxygen percentage for three weeks.

$\left\{\begin{array}{l|c|c|c|c|c|c|}\hline \multicolumn{1}{|c|}{\text { Percentage of oxygen }} & 5 & 10 & 20 & 40 & 60 & 80 \\ \hline \text { Experimental material } & & & & & \\ \hline \text { Huhman tubercle bacilli (Aoyama B.) } & 1.6 & 1.7 & 1.6 & 0.9 & 2.7 & 2.9 \\ \hline \text { Huhman tubercle bacilli (Kamiike III.) } & 1.3 & 1.6 & 1.8 & 1.5 & 2.9 & 3.2 \\ \hline \text { Huhman tubercle bacilli (Matsumoto) } & 1.2 & 1.6 & 1.4 & 1.1 & 2.4 & 2.5 \\ \hline \text { Average } & 1.4 & 1.6 & 1.6 & 1.1 & 2.7 & 2.9 \\ \hline \text { Bovine tubercle bacilli (No. 3) } & 1.5 & 1.5 & 1.9 & 1.2 & 1.3 & 2.4 \\ \hline \text { Bovine tubercle bacilli (No. 6) } & 1.7 & 1.8 & 1.2 & 0.8 & 1.4 & 2 \\ \hline \text { Bovine tubercle bacilli (No. 12) } & 1.0 & 0.9 & 1.2 & 0.9 & 1.0 & 1.6 \\ \hline \text { Bovine tubercle bacilli (No. 14) } & 1.6 & 1.4 & 1.2 & 0.9 & 1.4 & 2 \\ \hline \text { Bovine tubercle bacilli (Hokken) } & 1.3 & 1.3 & 1.6 & 1.3 & 1.7 & 2.0 \\ \hline \text { Average } & 1.4 & 1.4 & 1.4 & 1.0 & 1.4 & 2.0 \\ \hline \text { B. C. G. } & 2 & 2.2 & 3 & 3 & 3.2 & 3.4 \\ \hline \text { Avian tubercle bacilli } & 1.6 & 1.8 & 1.7 & 1.6 & 1.1 & 1.1 \\ \hline \text { Timothy bacilli } & 1.4 & 1.2 & 1.3 & 1.0 & 1.0 & 0.9 \\ \hline\end{array}\right.$

Table XXIX 八各種抗酸性菌ノ1mg. 發育二要スル酸素量きー括シテ表示シタルモ ノニシテ今人型結核菌，酸素消費量 キ見ルニ5\%乃至 $20 \%$ 間二於テハ 1.2 c.c. 乃至 1.8c.c. ニテ $40 \%$ ニテー般二低下シ 0.9c.c.乃至 $1.5 \mathrm{ccc}$. ナリ。而シテ $60 \%$ 以上ニ於テ 2.4 c.c. 乃至 3.2c.c. 二テ酸素消費量多シ。又牛型結核菌，酸素消費量 キ見ル $=5 \%$ 乃至 20 $\%$ ，間二於テ～ $0.9 \mathrm{ccc}$. 乃至 $1.9 \mathrm{ccc}$ 二シテ $40 \%$ 二テ低下シ $0.8 \mathrm{ccc}$. 乃至 $1.3 \mathrm{c} . \mathrm{c}$ 二シテ 60 \%以上二於テハ $1.0 \mathrm{ccc}$ 乃至 2 c.c. ナリ。

今人型結核菌及ビ牛型結核菌ノ酸素消費量 キ比較スルニ $40 \%$ マデハ兩型ノ酸素消 費量 間二著明ナル差異キ認メザルモ $60 \%$ ニハ人型結核菌，酸素消費量ハ $2.7 \mathrm{ccc}$.

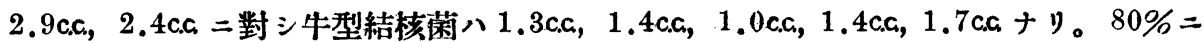


テ 八人型結核菌，酸素消費量２.9c.c., 3.2 c.c., 2.5 c.c. 二對 シ牛型結核菌ハ 2.4 c.c., 2 c.c., 1.6c.c., 2c.c., 2 c.c. 二シテ $60 \%$ 以上, 酸素，濃度二テ八人型結核菌，方酸素消費量多 シ。今人型結核菌，酸素消費量，本均値キ求ムレバ $5 \%=$ テ 1.4 c.c., $10 \%$ テ 1.6 c.c., $20 \%=$ テ 1.6 c.c., $40 \%$ テ 1.1 c.c., $60 \%$ テ 2.7 c.c., $80 \%$ テ 2.9 c.c. ニシテ牛型結核 菌，酸素消費量，本均値キ求ムレバ. $5 \%$ 二テ 1.4 c.c.， $10 \%$ =テ 1.4 c.c.，20\%=テ 1.4 c.c., $40 \%$ ニテ 1.0 c.c., $60 \%$ ニ 1.4 c.c., $80 \%$ ニ 2 c.c. ニテコレチ curve ニテ表ハス 時八Chart 18 八如 シ郎于實線八人型結核菌，酸素消費量， curve，點線八牛型結核 菌ノ酸素消費量, curve チ示ス。60\%以上二於テ人型結核菌ノ消費量, curve 著シ ク高シ。

\section{Chart 18.}

The consumed oxvgen curve of human and tovine tubercle bacilli grown on glycerol broth in the different oxygen percentage.

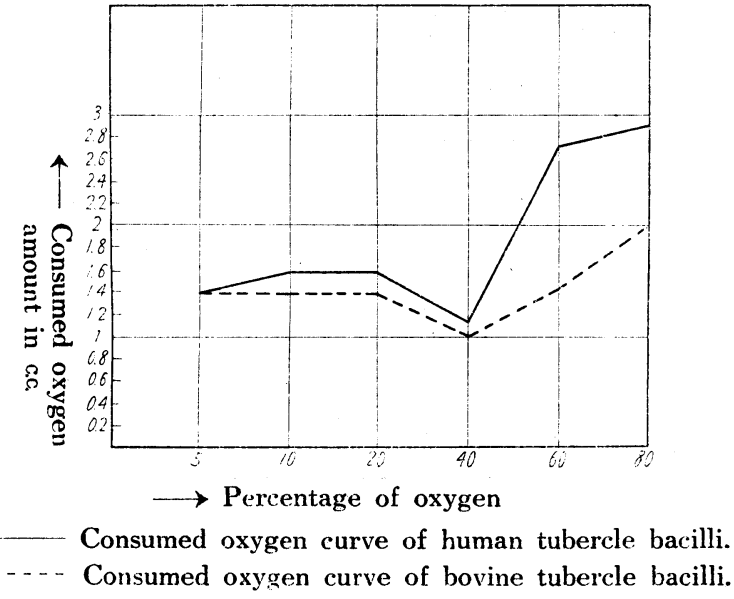

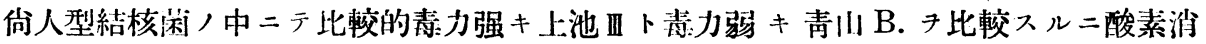
費量ノ點二於テハ著シキ差異チ認メズ又牛型結核菌中毒强キNo. 6, No. 12 卜毒: 力四キ No. 3, No. 14, 北呼/酸素消費量キ比較スルモ Akszauzew ノ云フガ如キ 著明ナル差異き涊ムル事困難ナリ。

次二 B.C.G. 八酸素消費量キ見ル二他ノ結核菌ト異ナッ酸素ノ全テノ濃度二於テ他 ノ結核菌ヨリ酸素消費量多シ。今人型結核菌及ビ牛型結核菌チ合シテソノ酸素消費量 ノ本均值テ求ムル時ハ $5 \%$ テ 1.4 c.c., $10 \%$ テ 1.5 c.c., $20 \%=$ テ 1.5 cc., $40 \%$ テ 1.0 c.c., $60 \%$ テ 2c.c., $80 \%$ \%ニテ 2.4c.c. ニシテ 1c.c. 乃至 2.4c.c.ナルニ對シ B.C.G. 八 2c.c. 乃至 3.4c.c. ナリ。而シテ B.C.G. 八酸素ノ濃度增スト共二酸素消費量モ增加シ又 結核菌ノ如ク $40 \%$ テ酸素ノ消費量ノ低下キ來スコトナシ。 
次二鳥型結核菌ノ酸素消費量き見ルニ 1.1 乃至 1.8 c.c.ニシテ結核菌ノ酸素消費量ト 著明ナル差異ナシ而レ共結核菌及ビ B.C.G. ト異ナルトコロ八濃度ノ增スト共二酸素 消費量八減少ス。

及 Timothy 菌ノ酸素消費量ハ 0.9 乃至 1.4c.c. 間ニアリ。而シテ鳥型結核菌ト curve ノ動キキ同ジクシ酸素ノ濃度ノ增スト共二消費量八減少ス。

今人型牛型兩結核菌/酸素消費量ノ本均值き curve ニテ表ハシ B.C.G. 及ビ鳥型 結核菌及ビ Timothy 菌ノ酸素消費量, curveトチ比較スル時ハ Chart 19 /如シ。

Chart 19.

The consumed oxygen curve of tubercle bacilli and B. C. G. and avian tubercle bacilli and timothy bacilli grown on glycerol broth in the different oxygen percentage.

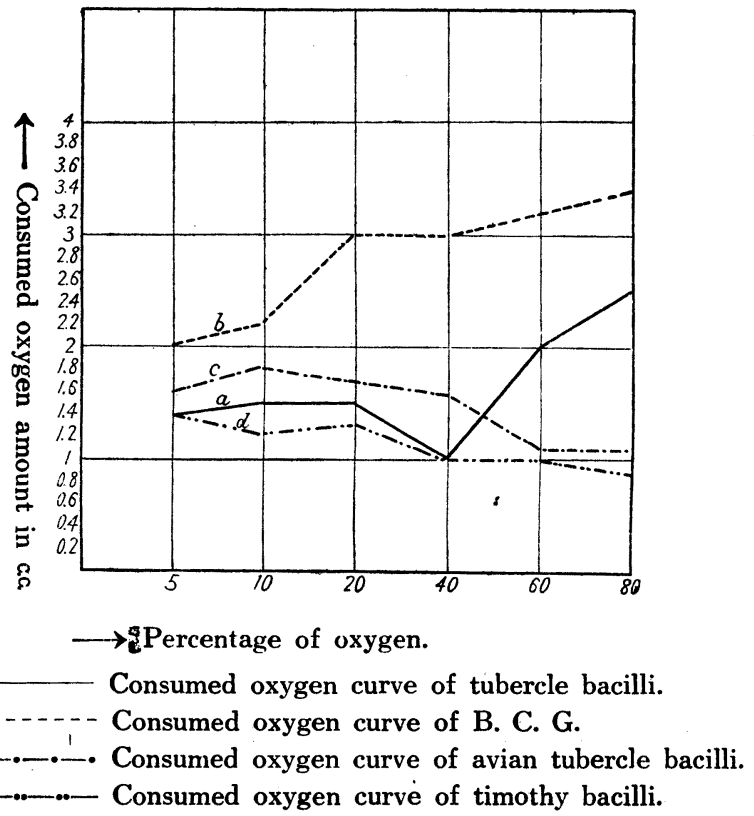

a 線八人型牛型兩結核菌ノ本均値, curve キ表ハシ, b 線ハ B.C.G., c 線ハ鳥型 結核菌, $d$ 線八Timothy 菌八酸素消費, curve チ示ス。

節チ B.C.G. 八他ノ抗酸性菌二比シ酸素消費量著明ナリ。而シテ酸素,濃度ノ增ス 卜共二 curve 八上昇ス。結核菌及ビ鳥型結核菌, Timothy 菌, curve 八共= $40 \%$ マデ 1c.c. 乃至 2 c.c. ノ間き上下シ $40 \%$ 二於テ一度降下シタル結核菌， curve 八再ビ上 昇スルニ反シ鳥型結核菌及ビ Timothy 菌, curve ハ $40 \%$ 以上ニテ更二下降ス。 


\section{第五重 結 論}

1）本實驗 八人型結核菌靑山 B., 上池田., 松本及ビ牛型結核菌 No. 3, No. 6 , No. 12, No. 14, 北研及ビ B.C.G., 鳥型結㤥菌, timothy 菌,十一種類, 抗酸性菌尹. 5 , $\%$ ，glycerol broth 二培養シソノ呼吸商 測定シ又 $5 \%$ 乃至 $80 \%$ ，酸素，濃度， 下二於ケル發育菌量及ビ酸素消費量 キ测定シテ各菌種間ノ差異 キ見ントシタルモノ ナリ。

2)牛型結核菌，呼吸商八 0.8431 , 人型結核菌，呼吸商八 0.8342 , 鳥型結核菌，呼 吸商八 0.8295 二シテ本均 0.8356 ナリ。

B.C.G. /呼吸商八 0.8197 , timothy 菌/呼吸商八0.8591 ナリ。

3) 人型及ビ牛型兩結核菌ノ酸素ノ最適濃度ハ $40 \%$ 乃至 $50 \%$ ニテ B.C.G. ハ10 $\%$ 乃至 $20 \%$, 鳥㤠結核菌及ビ timothy 菌ハ60\%乃至 $70 \%$ リ。

4) 人型結核菌, 乾燥菌量 $1 \mathrm{mg}$.發育二要スル酸素消費量八 $5 \%$ 乃至 $40 \%$ / 酸素分 壓,下二テハ 0.9 c.c. 万至 1.8 c.c. ，間ニアリテ $40 \%$ 酸素分壓ノ下二テ最低值チ示ス。 $60 \%$ 乃至 $80 \%$ /酸素分壓,下二テハ 2.4 c.c. 乃至 3.2 c.c. ，間二在リ。牛型結核菌／乾 燥菌量 $1 \mathrm{mg}$. 發有二要ス儿酸素消費量八 $5 \%$ 乃至 $40 \%$ /酸素分壓，下二テハ 0.8 c.c.

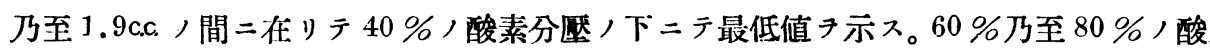
素分壓，下二テハ 1c.c. 乃至 2.4 c.c. ，間二在リ。郎于 $5 \%$ 乃至 $40 \%$ ／酸素分壓，下二 テハ人型牛型兩結核菌，酸素消費量ニ八著明ナル差異キ認メザルモ $60 \%$ 乃至 $80 \%$ ， 酸素分厴,下二テハ牛型菌, 方人型菌二比シ酸素消費量㽔カニ少ナシ。

5) B.C.G. 八乾燥菌量 $1 \mathrm{mg}$. 發有二要スル酸素量八 $5 \%$ 乃至 $40 \%$ / 酸素分壓,下 二テハ 2 c.c. 乃至 3 c.c. ，間二任り $60 \%$ 乃至 $80 \%$ ／酸素分涯下二テハ 3.2 c.c.j至 3.4 c.c. ナリ。郎于他ノ抗酸性菌ヨリ全テノ酸素分壓ノ下二テ酸素消費量遙カ二多ク而シテ 酸素，濃度，增ス卜共二酸素消費量モ又增加入。

6) 鳥型結核菌ノ乾燥茵量 $1 \mathrm{mg}$. 發育二要スル酸素量八 $5 \%$ 乃至 $80 \%$ /酸素分㕍 ノ下二テ 1.1 c.c. 乃至 1.8 c.c. 八間二在リテ酸素, 濃度ノ增スト共二酸素消費量八反對二 減少入。

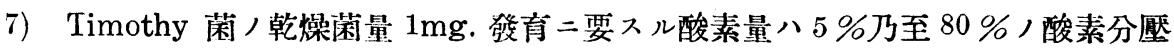
ノ下二テ 0.9 乃至 $1.4 \mathrm{ccc}$. ニシテ鳥型結核菌同樣酸素,濃度ノ增ス卜共二酸素消費量八 反對二減少ス。

8）上上ノ如ク本實驗二於テ八酸素消費量，點二於テ人型及ビ牛型兩結核菌 ハ60 
\%乃至 $80 \%$ ＼cjkstart酸素，高分厘，下二於テ其差異著明ナリ。而シテ弱毒菌 B.C.G. 八他 ノ抗酸性菌ヨリ全テノ酸素分壓ノ下二於テ酸素消費量大ナリ。然シ病原性ノ結核菌中 ノ强毒ノモノト弱毒ノモノト, 間二八酸素消費量ノ點二於テ著明ナル差異ナシ。又鳥 型結核菌及ビ timothy 菌ハ $5 \%$ 乃至 $40 \%$ 酸素分壓,下二テ八人型, 牛型兩結核菌 ノ酸素消費量卜大差ナケレ共 $60 \%$ 乃至 $80 \%$ ノ酸素ノ高分涯ノ下ニテハ人型牛型兩結 核菌ヨリ酸素消費量少ナシ。

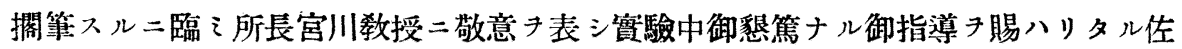
藤教授二厚ク感謝ノ意尹表入。

\section{主要文獻}

1) Novy and Soule, The Journal of inf. disceases, Vol. 36, 1925. 2) Y. Aoki, La Lepra, Bd. III, Nr. 3, 1932. 3) Soule and Mckinley, The Journal of A. M. A., Vol. 98, No. 5, 1932. 4) Marie et Tiffeneau, Soc. de Biologie, 1912, 72, 486. 5) A. Trouin, Soc. de Biologie, 1913, 74, 1184. 6) Wherry and Ervin, Journal of inf. disceases, 1918, 22, 194. 7) Corper, Gauss and Rensgh, Amer. Rev. of Tuberculosis, 1921, 5, 562. 8) Ludwig, Lange, Centralblatt für Bacteriologie, Bd. 327, 1932. 9) R. O. Loebel, E. Shorr, The Journal of bacteriologie, Vol. XXVI. No. 2, 1933. 10) M. Akszauzew, Zeitschrift für Immunitätsforschung \& exp. Therapie Bd. 79. Heft 3/4 1933. 11) V. Bisceglie u. A. Juhâsz-schäffer, Die Gewebezïchtung in vitro. 1928. 12) Peter Rona, Prakticum der physiologischen Chemie (Stoffwechsel u. Energiewechsel). 13) Tetsuka, The Japanese Journal of exp. med. April, 20, 1934. 14) W. Stiles and W. Leach, Respiration in plants, 1933. 15) M. L. Plantefal, Bulletin de la societe de chimie biologique, Juni. 1932. 16) Van Slyke, Quantitative clinical chemistry, Vol. II, 1932 . 17) Kuroya, The Japanese Jour. of exp. med., Sep. 1929. 18) Moore and Williams, Bioch. Journ., 1909, 4, 177, and 1910, 5, 181. 19) Adam, Bioch. Journ., 1912, 6, 297. 20) Buchmann, Physiologie and biochemistry of bacterien, 1930. 21) Dieckmann u. Mentzell, Zeitschrift für Hygn. u. Inf., Bd. 113. H. 4. 22) Hersteller, Deutsche med. Woch., Den 12. Mai 1933. 23) Wakabayashi, The Japanese Journal of exp. med., July $20,1933.24$ ) 四方, 氣體分析化學. 1932.25$)$ 藤田, 檢怔法トソ, 應用. 1933. 